\author{
Universidade de São Paulo \\ Instituto de Física \\ Instituto de Química \\ Instituto de Biociências \\ Faculdade de Educação
}

\title{
Interações Verbais e Cognitivas: Uma Análise de Aulas Contextualizadas de Química
}

Fabio Luiz de Souza

Orientadora: Profa. Dra. Maria Eunice Ribeiro Marcondes 


\author{
Universidade de São Paulo \\ Instituto de Física \\ Instituto de Química \\ Instituto de Biociências \\ Faculdade de Educação
}

\title{
Interações Verbais e Cognitivas: Uma Análise de Aulas Contextualizadas de Química
}

Fabio Luiz de Souza

Orientadora: Profa. Dra. Maria Eunice Ribeiro Marcondes

Dissertação de mestrado apresentada ao Instituto de Física, ao Instituto de Química, ao Instituto de Biociências e à Faculdade de Educação da Universidade de São Paulo para a obtenção do título de Mestre em Ensino de Ciências. 
FICHA CATALOGRÁFICA

Preparada pelo Serviço de Biblioteca e Informação

do Instituto de Física da Universidade de São Paulo

Souza, Fabio Luiz de

Interações verbais e cognitivas: uma análise de aulas contextualizadas de química. São Paulo, 2007.

Dissertação (Mestrado) - Universidade de São Paulo. Instituto de Química, Instituto de Física, Instituto de Biociências e Faculdade de Educação.

Orientador: Profa. Dra. Maria Eunice Ribeiro Marcondes

Área de Concentração: Ensino de ciências

Unitermos: 1. Química - Estudo e ensino; 2. Interações verbais e cognitivas; 3 Contextualização; 4. Analise do discurso. 
Para

Marina, minha mãe, por acreditar em mim quando poucos ousaram fazê-lo.

Para

Dulce, minha esposa, e Letícia, minha filha, pelo apoio, abnegação e paciência em todos os momentos desta longa caminhada. 


\section{Agradecimentos}

A Deus, meu Pai, a Jesus Cristo, meu Senhor, e ao Espírito Santo, meu Mestre e Consolador, que me deram tudo que tenho e aquilo que ainda vou ter. A vós consagro esta dissertação e meu título de mestre.

A meus pais, Marina e Manoel, pela vida que me deram, suprindo-me em educação, sustento e amor.

A minha amada esposa, Dulce, que desde o primeiro ano da graduação até este momento tem me apoiado em tudo. Sem tua força não teria chegado até aqui.

A minha filha linda, Letícia, que é a alegria de minha casa.

Aos meus irmãos Carlos, Edson, Dani, Silvana e Oséas pela amizade e apoio.

Aos meus muitos irmãos na fé que sempre me ajudaram com amizades sinceras e orações. Pastores William e Marta, Hélio e Renata, vocês fazem parte desta conquista.

A Eunice, minha querida, sábia e paciente professora e orientadora, pelo muito tempo e atenção dispensados e pelos exemplos de ética profissional e comprometimento com a educação mostrados.

Aos amigos do GEPEQ - IQUSP e da pós, Eri, Luciane, Nilza, Simone, Miriam, Denilse, Gislaine, João, Robson, Murilo, Milton, Hebe, Fernanda, Professoras Yvone e Isaura, Renata, Rita, Daniele, Ângela, Marcela, Leonardo, Hélio e outros tantos que marcaram presença em meu dia-a-dia nestes últimos anos.

Aos amigos e mestres Marcelo, Edson, Viviani, Alexandra e Fátima, que já estão espalhados pelas universidades deste Brasil formando nossos futuros professores de Química.

Às professoras e aos alunos que participaram desta investigação e contribuíram de tão bom grado com um pouco de si mesmos.

A todos os que em maior ou menor grau fizeram parte desta vitória, meu muito obrigado. 


\section{RESUMO}

A contextualização dos conhecimentos científicos e a necessidade da participação ativa dos estudantes na construção coletiva dos discursos em sala de aula são dois importantes referenciais teóricos e metodológicos assumidos de forma quase consensual por professores de Ciências e pesquisadores da área, além de encontrar forte respaldo nas propostas oficiais do Ministério da Educação. Acredita-se que a contextualização leve os estudantes a uma maior participação durante as aulas e, assim, à aprendizagem dos conteúdos científicos.

Sendo assim, buscou-se nesta investigação conhecer a natureza e a dinâmica das interações discursivas construídas por professor e alunos em aulas de Química em que o conhecimento científico é contextualizado.

Partiu-se da hipótese de que a inserção de conteúdos ligados ao cotidiano dos estudantes ou que envolvam as relações CTSA (Ciência-Tecnologia-Sociedade-Ambiente) pode não promover interações discursivas que evidenciem um alto grau de envolvimento cognitivo por parte dos estudantes.

Foram gravadas, transcritas e analisadas três aulas de duas professoras de escolas públicas diferentes, situadas próximo ao município de São Paulo. Essas aulas foram analisadas por apresentarem alguma forma de contextualização. As interações discursivas foram categorizadas nas dimensões verbal e cognitiva, ou seja, cada fala das professoras ou dos alunos foi enquadrada em uma categoria da dimensão verbal e em uma categoria da dimensão cognitiva.

A análise dos resultados mostrou um acréscimo das interações cognitivas mais elaboradas (Interações Cognitivas de Ordem Alta), principalmente no discurso das professoras, quando a aula era contextualizada. Apesar disso, as falas dos alunos se mantiveram curtas e pouco elaboradas, mostrando pouca relação com a qualidade das interações cognitivas apresentadas pelas professoras e com a contextualização dos conteúdos. A freqüência da participação dos alunos também não foi afetada pela contextualização, permanecendo elevada e constante. 


\begin{abstract}
The context based learning and the students' active participation in the classroom collective discourse construction are two important theoretical references consensually admitted by science teachers and educational researchers and is also endorsed by educational policy of Brazilian Ministry of Education. It's assumed that context based learning enhances the active students participation and improves scientific contents learning.

This research aims to understand the nature and dynamic of discursive interaction which take place between teacher and students in a context based chemistry classroom.

The hypothesis was that the insertion of contents connected to the students daily life or that involve STSE (Science-Technology-Society-Environment) not necessarily promote discursive interactions that evidence a high student cognitive involvement.

Three classes of two different public schools chemistry teachers were recorded, transcribed and analyzed. These classes were chosen because they presented some kind of context-based situation. The discursive interactions were categorized in verbal and cognitive dimensions. Each teacher's or students talks was classified in a verbal dimension category and in a cognitive dimension category.

The analysis of the result showed an increase of the more elaborate cognitive interactions (Higher Order Cognitive Skills) when the class content was context based, mainly in the teachers discourse. Despite that, the students' talk remained short and less elaborated, showing little relation with the quality of cognitive interactions presented by teachers and with the context-based nature of the content. The frequency of the students' participation also wasn't affected by the context-based subject, it was high and constant.
\end{abstract}




\section{SUMÁRIO}

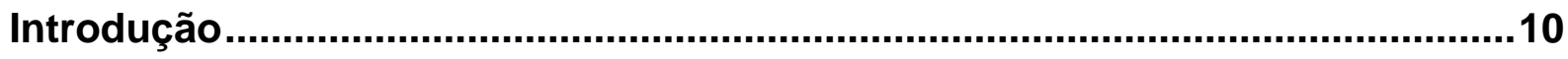

1 - Fundamentação......................................................................................12

1.1 - Interações em sala de aula ..................................................... 13

1.2 - Sobre a análise do discurso em sala de aula........................................ 16

1.3 - A contextualização no ensino de ciências em uma aproximação introdutória ao movimento CTS - Ciência-Tecnologia-Sociedade - e suas variantes ...............18

2 - Revisão Bibliográfica: ............................................................................30

2.1 - Pesquisas sobre interações aluno-aluno: enfoque nas atividades em grupo 30

2.2 - Pesquisas sobre interações professor-aluno ......................................... 35

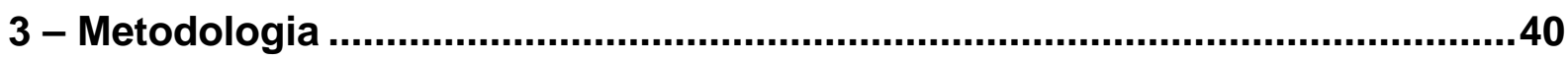

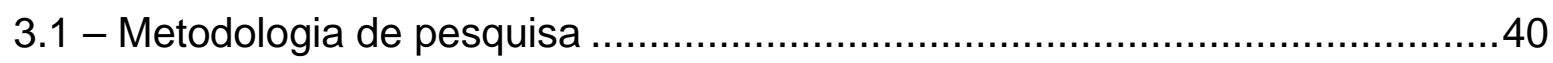

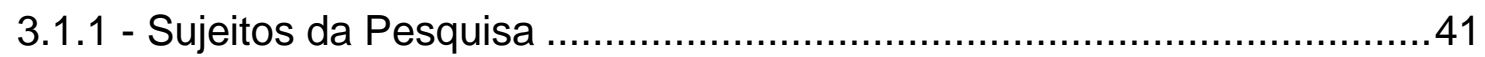

3.1 .2 - Registro dos dados e transcrições ......................................... 43

3.2 - Metodologia de análise dos dados ............................................. 44

3.2.1 - Interações cognitivas de Alta e de Baixa Ordem ...........................45

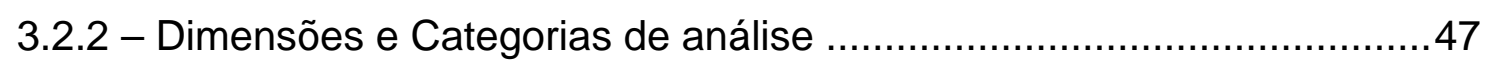

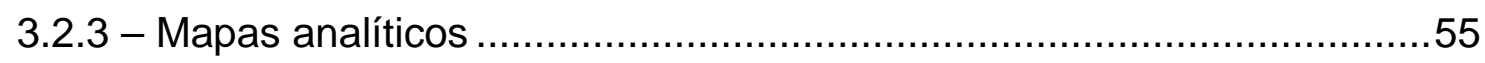

3.2.4 - Análise qualitativa interpretativa .........................................56

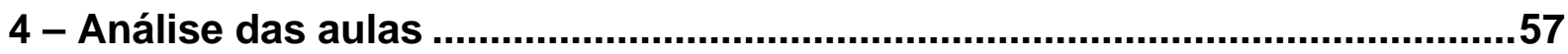

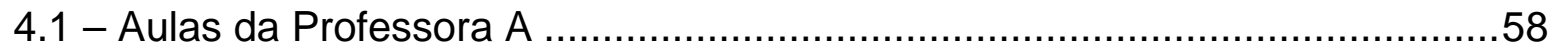

Episódio 1 da aula 1 da professora A (E1A1PA) ....................................58

Episódio 2 da aula 1 da professora A (E2A1PA) ...................................64

Episódio 3 da aula 1 da professora A (E3A1PA) ......................................65

Episódio 4 da aula 1 da professora A (E4A1PA) .....................................68

Episódio 5 da aula 1 da professora A (E5A1PA) ................................... 71

Episódio 6 da aula 1 da professora A (E6A1PA) ................................... 73

Episódio 7 da aula 1 da professora A (E7A1PA) .................................... 78

Episódio 8 da aula 1 da professora A (E8A1PA) ...................................... 80

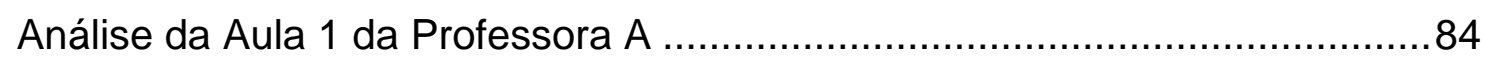

Episódio 1 da aula 2 da professora A (E1A2PA) ..................................... 88

Episódio 2 da aula 2 da professora A (E2A2PA) ........................................ 92

Episódio 3 da aula 2 da professora A (E3A2PA) ................................. 94 


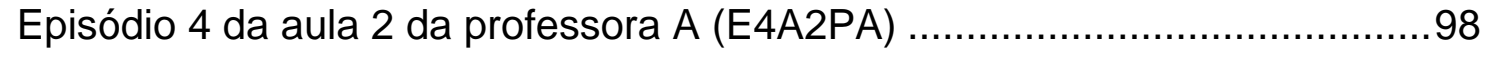

Análise da Aula 2 da Professora A .................................................. 102

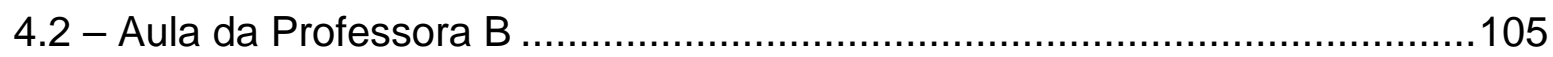

Episódio 1 da aula 1 da professora B (E1A1PB) ................................. 105

Episódio 2 da aula 1 da professora B (E2A1PB) ................................... 109

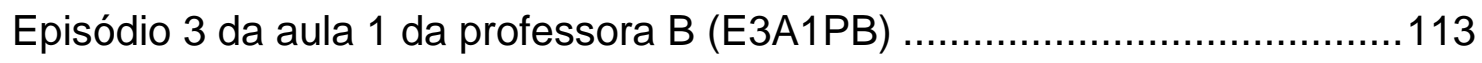

Episódio 4 da aula 1 da professora B (E4A1PB) ................................. 125

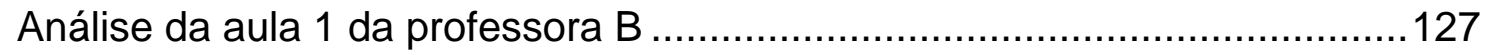

4.3 - Considerações gerais sobre as três aulas analisadas ...........................132

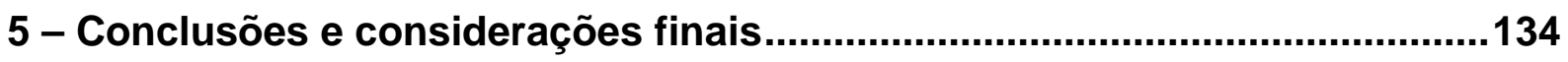

6 - Bibliografia e referências bibliográficas ................................................. 141 


\section{Introdução}

Uma vez, no início de minha caminhada acadêmica, logo nos primeiros meses do mestrado, quando ainda tinha poucas dúvidas e conflitos - porque percebi que estudamos para ter mais e melhores questionamentos e poucas, parciais e transitórias respostas - perguntei para um professor do programa de pós-graduação "Por que eu deveria usar citações de outros autores ao escrever um trabalho científico?" A resposta para minha pergunta 'infantil', inocente, mas também genuína, foi esclarecedora e igualmente sincera: "Porque aquilo que a gente quer dizer, alguém já disse antes e de uma forma melhor"!

Assim, encontrei num capítulo de livro, escrito pela professora Elsa Garrido há uma década, aquilo que eu queria ter escrito, mas que ela já escreveu antes. Então, só me resta citá-la.

A função do professor questionadora e encorajadora do debate e da investigação, que remonta a Sócrates, ganha aqui nova dimensão [Ela falava sobre as idéias propostas por Posner e Strike (1982) em seu famoso artigo sobre mudança conceitual]. Cabe ao professor estimular o pensamento cooperativo, engajando os alunos na busca de explicações para os fenômenos que os cercam. Ao tentarem explicar e explicitar as idéias tomam consciência de suas próprias concepções. Enriquecem-se com as colocações e argumentações dos companheiros. Cabe ao professor sobretudo a tarefa de promover o debate com o objetivo de ressaltar o confronto das opiniões com os dados ou a contradição entre diferentes pontos de vista, de modo a tornar o aluno intelectualmente insatisfeito com suas próprias concepções e aberto a elaboração de novas explicações ou à apresentação do modelo científico. A ruptura do aluno com a concepção ingênua do mundo requer que a classe seja um espaço em que os estudantes pensem e não simplesmente um espaço em que o professor informa sobre a visão de mundo dos cientistas (GARRIDO, 1996, p.180181).

Embora o modelo de mudança conceitual proposto por Posner não seja um referencial teórico explícito neste trabalho de pesquisa, não posso negar que suas contribuições estão fortemente arraigadas em minha forma de pensar a educação em ciências no que se refere à aprendizagem dos conceitos científicos. Mas, mais 
do que destacar as idéias do autor em si, gostaria de salientar as implicações desse modelo de aprendizagem na ação docente, como foi tão bem declarado pela autora.

As expressões "estimular o pensamento", "promover o debate", "ressaltar o confronto das opiniões com os dados ou a contradição entre diferentes pontos de vista" e "tornar o aluno intelectualmente insatisfeito com suas próprias concepções" ilustram o papel do professor de ciências na educação contemporânea. Quando digo "ciências" me refiro às disciplinas da área das ciências da natureza na educação básica, Ciências, Química, Física e Biologia.

Essas expressões relacionadas à função de ensinar ciências giram em torno da idéia central de que cabe ao professor promover diálogos com os alunos que resultem numa ação consciente e proposital de refletir sobre seu próprio conhecimento (metacognição) e sobre o conhecimento científico. Através desse processo dialógico e interativo entre professor e alunos e entre os próprios alunos estabelecem-se interações que podem promover uma aprendizagem significativa da ciência. Essa visão de educação científica tem sido compartilhada por muitos pesquisadores ao redor do mundo e se constitui, de forma quase consensual, em um paradigma - ou pelo menos um importante referencial - educacional neste início de século $X X I$.

Aliado à idéia da necessidade de interação em sala de aula, outro paradigma tem se estabelecido no campo da educação em ciência, a necessidade de contextualização do conhecimento científico.

O trabalho de investigação aqui apresentado busca tecer relações entre esses importantes referenciais educacionais - as interações em sala de aula e a contextualização dos conhecimentos científicos - no contexto da sala de aula de ciências (Química, neste caso).

São muitas as justificativas para a relevância desse tema de pesquisa. A maioria dos documentos legais que buscam nortear o ensino de ciências em nosso país tem como referenciais as idéias de promover a participação ativa dos estudantes nas aulas, principalmente pelo debate, e mostrar as inter-relações entre o conhecimento científico e o cotidiano dos alunos. Essas idéias são defendidas, por exemplo, nos Parâmetros Curriculares Nacionais para o Ensino Médio (PCNEM), tanto na primeira edição (BRASIL, 1999) quanto na edição mais atual (BRASIL, 2002) e na Proposta Curricular para o Ensino de Química da Secretaria da Educação do Estado de São Paulo (SÃO PAULO, 1992). Além desse respaldo legal, 
tem-se o forte amparo da comunidade acadêmica, como será visto na revisão bibliográfica, a uma forma de educação que preze o diálogo em sala de aula e o estreitamento da relação entre o conhecimento escolar/acadêmico e o cotidiano/social.

Nesta investigação, parto da hipótese de que a contextualização do conhecimento científico, embora necessária, não garante o estabelecimento de interações discursivas que evidenciem um alto nível de envolvimento cognitivo por parte dos alunos. Em outras palavras, defendo o ponto de vista de que a incorporação de conteúdos mais próximos a vivência dos alunos, mesmo que gere maior interesse e participação na aula, não leva necessariamente à construção de conhecimento, mas pode simplesmente redundar na troca dos conteúdos a serem memorizados e algoritmos a serem automatizados.

Desta forma, tenho como objetivo desta investigação conhecer a natureza das interações verbais e cognitivas estabelecidas entre professor e aluno e entre os próprios alunos nas aulas em que o ensino de Química é contextualizado.

Espero que, com os resultados obtidos a partir desta investigação, possamos compreender melhor tanto a dinâmica das interações em sala de aula quanto o papel da contextualização dos conhecimentos científicos nelas.

Para alcançar esse objetivo foram investigadas algumas aulas de professoras de Química que trabalham de forma contextualizada. As aulas foram gravadas em vídeo e suas transcrições analisadas a partir de um esquema de categorias desenvolvido para classificar as interações em duas diferentes dimensões: verbal e cognitiva.

\section{1 - Fundamentação}

É apresentada, neste capítulo, a maior parte do que constitui o referencial teórico desta investigação, a saber, como são compreendidas as interações em sala de aula, a análise do discurso em sala de aula, e a diversidade de formas de compreensão do que vem a ser ensino contextualizado. Somado a esta fundamentação tem-se a discussão sobre as interações cognitivas, que foi mais convenientemente encaixada no capítulo que aborda a metodologia da análise dos dados. 


\section{1 - Interações em sala de aula}

A sala de aula é um espaço privilegiado para a ocorrência de interações entre professores e alunos.

O fato é que as mudanças que têm ocorrido na sociedade nos padrões de comportamento, sobretudo das crianças e jovens, acabam por refletir na sala de aula. Embora alguns "focos de resistência" ainda existam, não se pode negar o quanto o estudante se sente mais à vontade para falar durante a aula. Essa fala, antes oprimida por uma noção de educação pautada no autoritarismo docente, tendo a nota como "arma de combate" e a reprovação como punição, tem sido cada vez mais presente na escola. É verdade que esse fenômeno tem muitas vezes resultado em desorganização e indisciplina nas aulas e provocado descontentamento, sentimento de revolta, descontrole emocional e insegurança em muitos professores, mas também tem aumentado a freqüência e qualidade das interações entre professores e alunos.

A possibilidade que hoje é dada ao estudante de expor suas dúvidas, questionamentos, conhecimentos e até mesmo críticas e opiniões é algo de excepcional do ponto de vista pedagógico, social e afetivo. O crescente número de trabalhos de investigação (CÁRDENAS et al., 2004; KUMPULAINEN; MUTANEN, 1999; SANTOS et al., 2001; CAPECCHI et al., 2000; GARRIDO, 1996) que têm coletado como dados de pesquisa os registros transcritos das conversas entre professores e alunos e entre os próprios alunos aponta nesse sentido.

Seria muito difícil investigar, por exemplo, como professor e aluno constroem o significado de determinado conceito durante o diálogo em sala de aula há algumas décadas atrás simplesmente porque não havia diálogo entre eles. A construção dos significados era realizada através de uma interação não dialógica de autoridade usando a terminologia proposta por Mortimer e Scott (2002) - onde o professor se porta como detentor da verdade e não considera as idéias dos alunos no processo de ensino. Em outras palavras, cabia ao professor transmitir a informação (não ensinar) e ao aluno a tarefa de decodificar as informações recebidas - muitas vezes na forma de símbolos, fórmulas, gráficos e diagramas -, estabelecer relações com os conhecimentos já adquiridos, reorganizar suas estruturas mentais, construir significados novos para os conceitos dados e organizar todo esse novo 
conhecimento de modo a poder comunicá-lo de forma clara e precisa ao professor. Mas, se o estudante não conseguisse fazer isso tudo sozinho, - o que é bastante provável - bastava decorar as definições dos conceitos ou "automatizar" a aplicação de alguns algoritmos que estava tudo bem.

Essa visão de educação, por mais dramática que possa parecer, representa de forma precisa uma realidade escolar que necessita com urgência ser superada. Para isso é preciso se deter com um pouco mais de afinco sobre as interações entre professor e alunos nas aulas, de maneira a problematizar, analisar e compreender mesmo que parcialmente - a dinâmica desses processos. Só assim será possível modificar o estado em que se encontra a complexa relação professor-conhecimentoaluno no sentido de promover uma construção efetiva, por parte dos educandos, dos conhecimentos necessários a sua formação como cidadãos e cidadãs críticos (as), conscientes e atuantes.

As interações em sala de aula têm sido, em geral, analisadas em três diferentes dimensões: verbal, cognitiva e social (KUMPULAINEN; MUTANEN, 1999). A primeira se refere ao caráter, propósitos e estratégias comunicativas das declarações feitas em sala de aula; a segunda dimensão se refere aos caminhos e estratégias cognitivas pelos quais o conhecimento é construído de forma individual ou coletiva na realização de atividades e resolução de problemas; e a terceira dimensão, a social, se debruça sobre as relações sociais estabelecidas entre os indivíduos durante as aulas.

É importante salientar que essas três dimensões das interações em sala de aula são intimamente relacionadas e que a delimitação de suas fronteiras é difícil e não consensual. É comum, por exemplo, que uma dada categoria de análise de uma investigação seja posta em outra dimensão de análise por outro investigador. Essa discrepância, longe de significar uma divergência de idéias, apenas mostra o quanto essa área de investigação carece de aprofundamento e fundamentação. Mostra também que a caracterização das diferentes dimensões e das categorias de análise a elas pertencentes depende muito do foco da pesquisa e da importância que o pesquisador dá a esta ou aquela dimensão.

Essa análise em três diferentes dimensões se faz necessária para o entendimento da complexa realidade da sala de aula. Os aspectos sociais, verbais e cognitivos, quando analisados separadamente, fornecem apenas impressões superficiais da dinâmica e estrutura das interações, mas quando suas relações são 
explicitadas podem fornecer uma compreensão mais aprofundada dessa problemática.

Nos últimos anos tem-se reconhecido a influência da linguagem (interação verbal) nos processos de construção individual e coletiva dos conceitos científicos (interação cognitiva) durante as aulas de ciências em todos os níveis da educação básica e superior (CÁRDENAS et al., 2004; CAPECCHI et al., 2000; ZOLLER, 1993). Outras investigações têm demonstrado que as interações sociais - incluindo aspectos afetivos, questões de gênero, papéis sociais e relações de poder - podem promover ou dificultar tanto a verbalização quanto a aprendizagem em ciências. Grande parte das investigações realizadas nos últimos anos sobre as interações entre professor e alunos nas aulas de ciências tem focalizado as relações sociais e os padrões lingüísticos das interações, ao passo que apenas a minoria dessas tem se detido às questões relacionadas ao aspecto cognitivo da construção do conhecimento científico.

O aspecto cognitivo das interações diz respeito às estratégias mentais que os indivíduos lançam mãos com o propósito de ensinar ou aprender determinado conteúdo. Por outro lado, ao analisar os aspectos verbais ou lingüísticos das interações busca-se conhecer quais as estruturas e os padrões do discurso coletivamente construído. No primeiro a preocupação é posta sobre o conteúdo da fala e no segundo sobre sua estrutura e forma. Ambos os aspectos são intimamente relacionados na medida em que o conteúdo que se busca ensinar e aprender é transmitido e recebido em grande parte pela oralidade. Embora essa mediação entre o objeto de conhecimento e o estudante possa ser feita por outros meios tais como livros, experimentos, problemas de lápis e papel etc., dependendo das atividades desenvolvidas, não se pode desprezar o papel do professor enquanto principal mediador do processo de ensino-aprendizagem e o fato de que este opera, sobretudo, por meio da oralidade.

Sobre a importância do professor na ação mediadora do conhecimento em sala de aula, Matui (1995) observa:

Assim, o papel do professor é promover a interação aluno/objeto de conhecimento. O que quer que o professor faça nas atividades de ensino montagem do ambiente, atividades pedagógicas, intervenções mediadoras, questionamentos e conversações dialógicas -, se não resultar na interação do aluno com o objeto de aprendizagem e vice-versa, nada absolutamente acontecerá de ação construtivista (MATUI, 1995, p. 196). 
Assim, é necessário aprofundar a discussão sobre a construção do conhecimento nas interações verbais e cognitivas entre professores e alunos e entre os próprios alunos de modo a apresentar contribuições tanto ao campo teórico-acadêmico para reflexões sobre os processos de ensino e aprendizagem quanto à prática docente cotidiana pela divulgação dos resultados obtidos junto aos professores. Neste último caso, a divulgação deve privilegiar os cursos de formação continuada e revistas de fácil acesso aos professores de Química, tal como a Química Nova na Escola, publicação da Sociedade Brasileira de Química.

Dois pontos fundamentais para o estabelecimento de um alicerce teórico para esta investigação precisam ainda ser abordados. O primeiro diz respeito à análise de discurso, tópico que poderia muito bem ser abordado no capítulo referente à Metodologia da Pesquisa, mas que por apresentar idéias fundamentais que transcendem esta investigação, decidiu-se abordar ainda na Fundamentação Teórica. $O$ segundo item refere-se às diversas abordagens dadas à contextualização no ensino de ciências. A importância desse segundo item deve-se ao fato de que é corrente a idéia de que um ensino contextualizado melhora as interações entre professores e alunos. Essa melhora seria evidenciada por uma participação mais ativa nas aulas e pelo aumento da motivação e interesse dos estudantes pela ciência. Essas idéias, além de constituírem algo como um "senso comum docente", também encontram forte respaldo no meio acadêmico, como será visto mais adiante.

\section{2 - Sobre a análise do discurso em sala de aula}

A análise do discurso de professores e alunos em sala de aula é uma importante ferramenta metodológica na pesquisa em educação em ciências (CANDELA, 1998). Contudo a maioria dos estudos sobre discurso em sala de aula é feita a partir da perspectiva da ação docente, dando pouca atenção para participação discente no processo de construção dos significados, e limita-se a descrever a estrutura do discurso. Considero que embora o conhecimento dessas estruturas e padrões discursivos tenha valor no âmbito da investigação em educação em ciências, por si só, suas contribuições são infrutíferas. É necessário, a meu ver, que tais conhecimentos sejam relacionados aos processos cognitivos, 
sociais e lingüísticos envolvidos na construção dos significados. Sobre isso o autor ainda declara:

A análise do discurso em sala de aula é um meio privilegiado para se compreender os mecanismos e as condições que propiciam a construção de significados (CANDELA, 1998, p. 143).

Essa construção de significados tem um aspecto de coletividade na medida em que diferentes vozes contribuem de maneira mais ou menos organizada e linear para a elaboração da idéia que se busca (re)construir e compartilhar, mas também tem um aspecto fortemente individualista e subjetivo. Nada garante que uma discussão constituída por contribuições de diferentes indivíduos resulte em uma interiorização das conclusões alcançadas no coletivo. Pelo contrário, deve-se considerar que um indivíduo pode contribuir positivamente numa discussão sem, contudo, alcançar o nível de generalização que se observa ao analisar superficialmente o discurso construído coletivamente. O autor vai ainda mais longe ao declarar:

A construção de significados num processo interativo com muitos indivíduos é um processo complexo, desigual e combinado, que evolui tanto para a construção de alguns significados compartilhados, quanto de outros complementares e alternativos (CANDELA, 1998, p. 144).

O autor atribui essa diferença na construção dos significados no processo discursivo às diferentes formas de interação e histórias de vida dos estudantes, o que resultaria na elaboração de diversas versões de um mesmo conteúdo. Como reflexo dessa singularidade de cada indivíduo, o autor sugere que no campo metodológico da investigação a construção das categorias seja feita a posteriori e não a partir de um "deve ser" marcado pelos modelos pedagógicos do pesquisador.

De Longhi (2000), ao comentar a singularidade de uma sala de aula, vai mais longe ainda ao questionar até mesmo a possibilidade de se identificar estruturas comuns nas interações entre professor e aluno em sala de aula:

Pelo caráter singular, assimétrico e intencional de cada turma, questionamos a possibilidade de identificar formas, tipos ou padrões na comunicação didática e preferimos buscar indicadores que permitam a interpretação a partir de um modelo didático específico para sua análise (DE LONGHI, 2000, p.202). 
Assim, não se deve analisar um discurso, construído coletivamente por muitas vozes, de forma seqüencial, mas como um todo, já que a mensagem pode estar relacionada a vozes social, espacial e temporalmente distantes. Não se pode também tirar conclusões sobre a construção do conhecimento individual de cada aluno somente a partir da estrutura e do conteúdo de tal discurso.

\section{3 - A contextualização no ensino de ciências em uma aproximação introdutória ao movimento CTS - Ciência-Tecnologia-Sociedade - e suas variantes}

O termo 'contextualização' não existe na língua portuguesa formal, mas tem sido amplamente utilizado no meio educacional para designar a inclusão de assuntos ligados aos contextos reais nos conhecimentos escolares. A contextualização dos conhecimentos científicos, ou seja, essa inclusão de conhecimentos ligados ao contexto social, cultural, tecnológico, ambiental, econômico, político, industrial, rural etc., aparece na literatura da área de ensino de ciências com os mais diversos nomes.

Embora o objetivo principal desta investigação não seja conhecer a forma de contextualização empregada pelos professores nas aulas de química analisadas, são aqui apresentados, em linhas gerais, alguns dos princípios e características mais marcantes de algumas das tendências mais disseminadas de contextualização dos conhecimentos científicos. São elas: (a) Ensino a Partir do Cotidiano, (b) Movimento CTS (Ciência, Tecnologia e Sociedade), (c) Movimento ACT (Alfabetização Científica e Tecnológica) e (d) Movimento CTSA, que surgiu com a incorporação mais recente (década de noventa) da questão Ambiental nas discussões sobre as relações entre Ciência, Tecnologia e Sociedade. Assim, aproxima-se a idéia de contextualização aos termos Ensino a partir do cotidiano, CTS, CTSA, ACT. São apresentadas a seguir algumas considerações gerais sobre cada um desses movimentos de contextualização na visão de alguns de seus mais proeminentes representantes.

Lutfi (1992) discute a contextualização dos conhecimentos científicos na educação em química a partir da noção do cotidiano do aluno. Ele apresenta cinco diferentes formas de compreender o ensino a partir do cotidiano como proposta de contextualização do conhecimento científico. 
Em um nível de menor complexidade e reflexão tem-se a idéia de que "trabalhar com o cotidiano trata-se de motivar os alunos com curiosidades" (nível 1). Aqui o conhecimento do cotidiano tem pouca ou nenhuma relação com o conteúdo da aula. As curiosidades que aparecem nas aulas são quase sempre ligadas a fenômenos extraordinários, sensacionais vinculados pela mídia e o interesse dos estudantes é fugaz, pois estão apenas em busca de respostas simples e imediatas, sem o objetivo de refletir e compreender profundamente o assunto.

Em segundo lugar está a compreensão de que "trabalhar com o cotidiano é buscar ilustrações para o assunto que se está desenvolvendo" (nível 2). Esse é o nível mais comum de contextualização. Nele buscam-se exemplos e contraexemplos para ilustrar o conteúdo da aula. Não há, contudo, uma reflexão mais profunda sobre as relações entre os conceitos científicos estudados e os aspectos tecnológicos, sociais ou econômicos do exemplo dado; limitando-se a mera exposição de exemplos e aplicações do conhecimento.

No terceiro nível temos os "projetos que procuram dourar a pílula" (nível 3). Nesse nível de contextualização o que é considerado realmente importante são os conceitos científicos, mas para que sejam assimilados mais facilmente ou "engolido com menos esforço" pelos estudantes usa-se de introduções no início de cada capítulo onde são apresentados dados históricos (geralmente mostrando uma evolução linear da ciência e ignorando sua relação de interdependência com a tecnologia e os aspectos histórico-sociais) ou levantam-se questões sobre saúde ou agricultura, mas sem abrir mão da seqüência tradicional dos conteúdos.

Os "projetos críticos quanto a seguir uma seqüência formal de conteúdos" (nível 4) surgiram nos EUA na década de 70 e apresentam como características marcantes a ruptura com a seqüência formal de ensino, o uso moderado da linguagem e simbologia química e a discussão aprofundada e bem fundamentada de questões como produção de alimentos e problemas ambientais, por exemplo. Apesar disso, esses projetos falham ao isentar os sistemas econômicos, sociais e políticos dos problemas sócio-ambientais causados pelo uso do conhecimento científico. Em vez disso simplesmente atribui-se a culpa ao 'mau uso da tecnologia' e não reconhecem que esses problemas são causados em decorrência de opções conscientes de desenvolvimento econômico.

Finalmente, o nível 5, o de maior complexidade e interesse para a educação em ciência é assim apresentado pelo autor: 
Uma quinta proposta de trabalho com o cotidiano, ligando-o ao conhecimento químico, considera esse cotidiano não como uma relação individual com a sociedade, pois existem mecanismos de acomodação e alienação que permeiam as classes sociais, mas considera a necessidade de fazer emergir o extraordinário daquilo que é ordinário, ou seja, buscar naquilo que nos pareça mais comum, mais próximo, o que existe de extraordinário, que foge ao bom senso, e que tem uma explicação que precisa ser desvelada. Para essa última visão de cotidiano, que implica em entender como o sistema econômico em que vivemos aparece em nossa vida diária, é que temos dirigido nosso trabalho de pesquisa em educação (LUTFI, 1992, p.15).

Essa idéia de contextualização como sendo um olhar reflexivo sobre as coisas comuns aos cidadãos, usando para isso os conhecimentos da ciência, tem suas raízes na década de 60 , enquanto movimento científico-filosófico de contestação e revisão das relações entre Ciência, Tecnologia e Sociedade, e na década de 80 como movimento educacional. Nas próximas linhas são tecidas algumas considerações sobre esses movimentos e suas proposições no campo da educação no ensino das ciências.

Talanquer (2000) destaca três grandes forças que têm provocado uma autêntica revolução do pensamento educativo a partir das duas últimas décadas do século $X X$, revolução resultante do surgimento de novos paradigmas que têm orientado as reflexões e interpretações daquilo que acontece (ou deveria acontecer) nas aulas de ciências.

Ele destaca primeiramente a influência das novas teorias cognitivas de aprendizagem, que, embora sejam constituídas de um leque muito grande de formas de pensamentos distintos, ora contraditórios em alguns aspectos, ora complementares em outros, têm sido abarcados pelo rótulo do construtivismo, em suas mais diversas variantes. Contudo, essas teorias cognitivas de aprendizagem apresentam como ponto de convergência o princípio básico de que o sujeito que aprende participa ativamente na construção de seu próprio conhecimento.

A segunda força promotora da revolução do pensamento educativo seria a transformação na visão de ciência por parte, primeiramente, dos filósofos da ciência, com destaque às idéias de Popper, Kuhn, Lakatos e Feyerabend, e depois dos próprios cientistas e educadores. Noções como "O conhecimento científico é conhecimento provado", "As teorias científicas derivam sempre da experimentação" ou "A observação dos fenômenos é sempre objetiva e imparcial" foram questionadas, revistas e substituídas por visões mais críticas da natureza da ciência 
e da construção do conhecimento científico. Sobre este segundo ponto, a transformação da visão de ciência ocorrida na segunda metade do século passado, Auler (2003) destaca que duas obras da literatura científica da década de 60 tiveram um impacto especial sobre a idéia, então hegemônica, de Ciência e Tecnologia (CT) como campos do conhecimento neutros e redentores da sociedade (visão salvacionista). A primeira delas, A Estrutura das Revoluções Científicas, publicada em 1962 pelo físico, historiador e filósofo da Ciência Thomas Kuhn, gerou novas reflexões, ao nível acadêmico, sobre a História e a Filosofia da Ciência ao questionar as tradicionais concepções relativas à construção do conhecimento científico. A segunda obra, denominada Primavera Silenciosa (Silent Spring), da bióloga Rachel Carson, foi publicada também em 1962. Essa, entretanto, teve maior impacto no âmbito social, em especial junto aos movimentos pacifistas e de conservação do meio ambiente. Nessa época, houve um movimento reivindicando um redirecionamento tecnológico, que se contrapunha à idéia de que um maior desenvolvimento de CT iria, automaticamente, solucionar os problemas sociais, ambientais e econômicos vigentes. Essas discussões tinham, acima de tudo, uma forte dimensão política. Pleiteava-se, em primeira instância, uma maior participação social na tomada de decisões relativas às questões de CT e buscava-se a ruptura com a visão tradicional/linear de progresso, isto é, a concepção de que o desenvolvimento científico gera desenvolvimento tecnológico e este, por sua vez, gera desenvolvimento econômico, que conduz ao desenvolvimento social.

Finalmente, temos a influência do movimento CTS (Ciência, Tecnologia e Sociedade) como terceira força impulsionadora da transformação do pensamento educativo no ensino de ciências.

A discussão das relações CTS tem sido motivada, por um lado, pelas pesquisas no campo da educação em ciências que têm mostrado o desinteresse e atitudes negativas dos estudantes com relação à ciência, por outro, pelo questionamento sobre o que é considerado hoje como sendo conhecimento básico para a formação de futuros cidadãos e cidadãs que possam se desenvolver em uma sociedade cada vez mais impregnada pelo desenvolvimento científico e tecnológico e que sejam capazes de tomar decisões conscientes frente aos problemas do mundo (SOLBES; VILCHES, 2000).

Aikenhead (2005), baseado nas idéias de Peter Fensham, destaca o fato de que as mudanças curriculares (incluindo aquelas que resultam numa maior inserção 
e valorização dos conhecimentos tecnológicos, sociais, ambientais e cotidianos no Ensino de Química) resultam de mudanças nas realidades sociais. No que diz respeito à incorporação de conteúdos CTS nos currículos das ciências, destacamse: a Segunda Guerra Mundial, o movimento ambiental, o movimento das mulheres, as reformas curriculares das ciências posteriores ao Sputnik (e a reação crítica dos anos setenta a esse movimento), as investigações sobre ensino e aprendizagem de ciências, a diminuição do interesse dos estudantes pela física (marcada pela queda no número de matrículas nos cursos de física) e a insistência de alguns educadores em apresentar a ciência aos estudantes de uma forma mais humanística, em lugar de um ensino elitista e propedêutico.

Essas mudanças, dentre outras, criaram um cenário propício a reformas fundamentais no currículo de ciências a partir dos anos oitenta. Nesse contexto, surgiram numerosas iniciativas que consolidaram o movimento CTS no campo da educação científica, dentre os quais Aikenhead destaca a criação de (a) projetos e programas de educação superior, tais como o SISCON (Science in a Social Context), na Inglaterra, (b) projetos escolares na Inglaterra, Holanda e Canadá, (c) publicação de revistas específicas sobre CTS e (d) centros de enfoque humanístico na educação científica em algumas universidades dos Estados Unidos da América, tais como Harvard, Stanford, Berkeley, lowa e no Instituto de Ontário de Estudos em Educação. Apesar dessa diversidade de ações para a promoção de uma educação CTS, Talanquer (2000) alerta para o fato de que as propostas educativas CTS são muitas vezes tratadas de forma trivial, chegando a ponto de adquirirem status de pré-concepções ou teorias alternativas de CTS. Ele cita, como exemplo, que "para alguns o enfoque CTS implica em renunciar o objetivo de que os estudantes compreendam os conceitos básicos de ciência e concebam os novos cursos como uma série de conferências de divulgação científica" (p.383).

No início do desenvolvimento do movimento CTS na educação científica, havia certa visão "cienciocêntrica", isto é, exploravam-se as implicações da ciência e da tecnologia sobre a sociedade sem, contudo, atentar ao papel da sociedade como agente transformadora da ciência e da tecnologia. Aos poucos, essa "via de mão única" foi dando lugar a uma abordagem mais interativa das relações CTS, onde são discutidas também a epistemologia, sociologia e história da própria ciência, bem como o contexto social externo a ela. 
Aikenhead (2005) propôs um esquema que apresenta oito diferentes graus de integração entre ciência, tecnologia e seus contextos sociais. Esses diferentes níveis de integração expressam a importância relativa concedida aos conteúdos CTS em relação aos conteúdos tradicionais, chamados por ele de "ciência canônica". A importância relativa é conferida de acordo com dois critérios: (1) estrutura do conteúdo, ou seja, a proporção de conteúdo CTS em relação ao conteúdo tradicional e a forma como ambos estão integrados, e (2) ênfase dada ao conteúdo CTS em relação ao conteúdo tradicional. Nesse esquema a categoria 1 equivale a menor prioridade atribuída ao conteúdo CTS e a categoria 8 a maior prioridade.

As categorias propostas foram:

Tabela 1: Categorias de CTS na ciência escolar (Aikehead, 2005)

\begin{tabular}{|l|l|}
\hline 1 & Motivação mediante conteúdos CTS \\
\hline 2 & Inclusão casual de conteúdos CTS \\
\hline 3 & Inclusão intencional de conteúdos CTS \\
\hline 4 & Disciplina particular de conteúdos CTS \\
\hline 5 & Ciência através de conteúdos CTS \\
\hline 6 & Ciência junto com conteúdos CTS \\
\hline 7 & Inclusão de ciência em conteúdos CTS \\
\hline 8 & Conteúdos CTS \\
\hline
\end{tabular}

Entre as categorias 3 e 4 ocorre uma mudança drástica na estrutura do conteúdo. Até a categoria 3 a estrutura do conteúdo é dada em função da ciência tradicionalmente ensinada, com inserções do conteúdo CTS. A partir da categoria 4 a estrutura do conteúdo é determinada pelos assuntos sociais e tecnológicos e a ciência passa a ser vista como um campo de conhecimento que é necessário para a compreensão das temáticas sociais e tecnológicas. Em outras palavras, há uma inversão de prioridades entre as categorias 3 e 4, indo de uma concepção de educação científica onde aspectos sociais e tecnológicos auxiliam a aprendizagem da ciência (compreender os conceitos científicos é o que realmente importa) para uma concepção onde a ciência é uma ferramenta cultural que possibilita uma compreensão de alguns aspectos relativos às temáticas sociais e tecnológicas (a interação entre ciência, tecnologia e sociedade é o que realmente importa).

Assim, a educação em ciências tem experimentado nas últimas duas décadas uma forte tendência a incorporação de conteúdos relacionados às temáticas sociais, tecnológicas, ambientais e do conhecimento cotidiano. Esse movimento tem se 
mostrado muito amplo e recebido diferentes denominações dependendo basicamente de dois fatores: Nível de integração entre as temáticas cotidianas ou sociais e os conteúdos científicos e tecnológicos, e Propósitos de seu ensino.

É importante destacar que a despeito de muitos professores se posicionarem favoravelmente à prática de um ensino contextualizado, não são tantos os que incorporam os princípios desse movimento educacional à sua prática docente cotidiana e quando o fazem, em geral, é de maneira simplista e mal fundamentada. Solbes e Vilches (2000), analisando pesquisas realizadas com 120 professores de Química e Física da Espanha, observaram que 67\% dos professores investigados simplesmente atribuem a ausência de conteúdos CTS no ensino de Ciências ao desinteresse dos estudantes, mas 90\% desses professores não consideram a presença de conteúdos CTS ao analisarem livros didáticos. Em etapas posteriores da investigação, desta vez com 56 professores e professoras de Química, os resultados mostraram que $69 \%$ dos entrevistados pensam que a finalidade prioritária do ensino de Química é a formação de futuros cientistas (químicos), ou seja, a preparação dos estudantes para os futuros cursos universitários de química ou outra ciência.

Pode-se dizer que a visão de ensino contextualizado de grande parte dos professores está relacionada ao uso de exemplos de fenômenos e substâncias do cotidiano como demonstração de aplicação dos conhecimentos científicos apresentados com vistas à motivação para o estudo, o que corresponde ao nível 1 de relação CTS, usando-se as categorias propostas por Aikenhead (2005), ou nível 2, usando-se as idéias de ensino a partir do cotidiano, apresentadas por Lutfi (1992). Por mais frustrante e simplista que possa parecer essa visão de contextualização, ela reflete claramente a compreensão da maioria dos professores sobre essa temática.

Pode-se dizer que a maioria das recomendações sobre a ACT por parte dos especialistas em todo o mundo inclui, segundo Acevedo Dias et al. (2003), muitas propostas próprias do movimento CTS, dentre as quais pode-se destacar:

- A inclusão da dimensão social na educação científica;

- A presença da tecnologia como elemento que facilita a conexão com o mundo real e uma melhor compreensão da natureza da CT contemporânea;

- A relevância para a vida pessoal e social das pessoas com objetivo de resolver problemas e tomar decisões responsáveis na sociedade civil; 
- As questões referentes à democratização da CT;

- A familiarização com os procedimentos de acesso a informação, sua utilização e comunicação;

- O papel humanístico e cultural da CT;

- Seu uso para propósitos específicos sociais e ação cívica;

- A consideração da ética e valores da CT;

- O papel do pensamento crítico etc.

Para esses autores a ACT pode ser tratada ou entendida como: (1) uma expressão que resume como palavra-chave os propósitos de reforma do ensino das ciências de um amplo movimento internacional de especialistas em educação científica; (2) uma metáfora que serve para expressar de maneira geral as finalidades e objetivos da educação científica e (3) um mito cultural que, embora expresso originalmente a partir de uma perspectiva crítica, se pode reformular como utopia que assinala o ideal a perseguir.

Segundo Auler (2003), o rótulo ACT tem sido traduzido através de expressões como Popularização da Ciência, Divulgação Científica, Entendimento Público da Ciência e Democratização da Ciência. A ACT tem apresentado duas formas principais, a perspectiva reducionista e a ampliada. Na primeira o ensino das ciências recebe apenas alguns incrementos de questões ligadas ao impacto da CT na sociedade, mas de forma acrítica e desproblematizada. Na perspectiva ampliada, por outro lado, busca-se a compreensão das interações CTS, associando o ensino de conceitos à problematização de situações sociais de interesse para os estudantes e comunidade escolar. A ACT está alicerçada, então, sobre os pressupostos de dois referenciais, o movimento CTS, já discutido anteriormente, e a concepção educacional de Paulo Freire.

A proposta educativa ACT, por ser fundamentada nas idéias freireanas, defende a articulação dos conhecimentos numa abordagem temática, em oposição à proposta educativa tradicional, que prima por uma abordagem conceitual.

Delizoicov, Angotti e Pernambuco (2002) definem abordagem temática como uma

Perspectiva curricular cuja lógica de organização é estruturada com base em temas, com os quais são selecionados os conteúdos de ensino das disciplinas. Nesta abordagem, a conceituação científica é subordinada ao tema (p. 189). 
Já a abordagem conceitual, segundo os mesmos autores, é definida como uma

\begin{abstract}
Perspectiva curricular cuja lógica de organização é estruturada pelos conceitos científicos, com base nos quais se relacionam os conteúdos de ensino (p.190).
\end{abstract}

Assim uma educação para ACT pressupõe uma ruptura com o paradigma curricular tradicional, passando de uma estrutura curricular pautada nos conceitos científicos para uma estrutura baseada em temas de relevância social. Essa abordagem temática deve incluir situações significativas para os estudantes, ou seja, situações-problema que surgem como manifestações das contradições envolvidas no tema. As situações-problema devem se apresentar aos estudantes tanto como desafios para a compreensão dos problemas envolvidos no tema, quanto como um convite conscientizador para que eles atuem de forma transformadora nas situações problematizadas durante o desenvolvimento do programa de ensino.

A enorme diversidade de expressões e rótulos atribuídos às diferentes formas de contextualização provocam importantes debates no campo do currículo. Um dos pontos apresentados por Acevedo Dias et al. (2003) é a divergência de interpretações sobre a expressão 'ciência para todas as pessoas'.

\begin{abstract}
Há um problema importante em torno do significado da expressão 'ciência para todas as pessoas', pois alguns o interpretam como os mesmos conteúdos de ciência escolar para todos os estudantes e outros como que, na educação contemporânea, todas as pessoas têm que dispor da ciência escolar para conseguir a alfabetização científica e tecnológica em maior grau possível, mas os conteúdos da ciência escolar deverão ajustar-se aos interesses e necessidades pessoais e da comunidade, seja esta local, regional, nacional ou internacional (ACEVEDO DIAS et al., 2003).
\end{abstract}

Para além de uma questão de regionalidade, esse embate se refere, sobretudo, ao direito dos estudantes de adquirirem os conhecimentos necessários para o exercício pleno da cidadania pela democratização de um saber científico que Ihes seja útil para tal. A questão posta, então, e para qual de antemão afirmo não ter uma resposta definida, é: o que é uma educação democrática - seja ela derivada de um modelo CTS ou não -, aquela que oferece os mesmos conhecimentos a todos os estudantes a fim de todos terem iguais oportunidades e condições de se 
desenvolverem ou aquela que aborda os aspectos mais próximos da realidade na qual os sujeitos estão inseridos, de modo a poderem transformá-la?

Da mesma forma que o rótulo 'ciência para todas as pessoas', a ACT é sempre ligada intimamente aos aspectos sociais e culturais, e, segundo os autores, é provavelmente impossível estabelecer um modelo universal para sua execução. Mesmo que os objetivos gerais do ensino sejam idênticos em diferentes localidades, não é necessário e nem desejável que os objetivos específicos também o sejam. Uma educação em ciências dessa forma - respeitando as diferenças sócio-culturais - possibilitaria um ensino de 'ciências para todas as pessoas' e uma ACT de modo que elas possam tomar decisões conscientes e embasadas também cientificamente em diferentes âmbitos da sociedade e sobre questões com diferentes níveis de complexidade.

Essa postura moderada é também apresentada nos Parâmetros Curriculares Nacionais para Ciências da Natureza, Matemática e suas Tecnologias (BRASIL, 2002):

Parte dos contextos tem sentido e alcance praticamente universais, podendo assim ser evocados em qualquer circunstância e escola. Haveria, contudo, um interesse especial em serem trabalhados contextos mais afins com a realidade ou situação particular, envolvendo uma certa escola e sua região ou comunidade (p.32).

A incorporação das questões ambientais às discussões sobre a contextualização dos conhecimentos científicos em suas relações com a sociedade e tecnológica é um fenômeno recente, tendo tomado impulso e visibilidade no meio acadêmico a partir da década de 90 do século passado.

Além do avanço da incorporação das questões ambientais ao ensino CTS, Uri Zoller (1987; 1993; 1999; 2000) e Zoller et al. (1995; 1997) têm colaborado com a investigação em ensino das ciências ao incluir e destacar em seus trabalhos a análise da dimensão cognitiva dos processos de ensino e aprendizagem nesse tipo de abordagem. Para ele os objetivos almejados pela educação CTS só podem ser alcançados se houver uma melhora das habilidades cognitivas desenvolvidas pelos estudantes. Para tanto, o objetivo do ensino de Química (e das outras ciências também) deve ser "desenvolver o raciocínio e as habilidades de pensamento crítico no contexto dos conteúdos e processos da ciência em geral e da química em 
particular, e desenvolver as capacidades de solução de problemas e tomadas de decisão" (ZOLLER, 1993).

Segundo o autor, o Ensino de Química tem desenvolvido nos estudantes quase que exclusivamente habilidades cognitivas de ordem baixa, denominadas de LOCS (Lower Order Cognitive Skills), por enfatizar demasiadamente a simples memorização de algoritmos (fórmulas, estruturas, esquemas) e conceitos científicos, a resolução de exercícios repetitivos e ausência de relações CTSA no ensino. O ensino, por outro lado, deveria estar voltado, segundo o autor, ao desenvolvimento de habilidades cognitivas de ordem alta, denominadas de HOCS (Higher Order Cognitive Skills). As HOCS estariam relacionadas à tomada de decisão, solução de problemas e sistema de pensamento crítico. Ele define pensamento crítico como sendo um "pensamento avaliativo, racional, lógico e 'conseqüencial' em termos de o que aceitar (ou rejeitar) e em quê acreditar, seguido de uma decisão (o que fazer (ou não fazer) sobre isso), seguido de uma coerente ação responsável" (ZOLLER, 1993, p.195).

Nas palavras do próprio autor:

A aquisição de HOCS pelos nossos estudantes é o maior objetivo instrucional do ensino contemporâneo de química (e ciências) (ZOLLER, 1993, p.195).

Essa diferenciação das habilidades cognitivas em dois níveis (ordem alta e ordem baixa) será discutida mais adiante na metodologia de análise e se constitui como um importante referencial teórico neste trabalho.

A despeito da denominação empregada para as várias formas de contextualização do conhecimento científico (Ensino a Partir do Cotidiano, Ciência para Todas as Pessoas, CTS, CTSA, ACT) cabe ressaltar alguns pontos comum a esses movimentos pedagógicos ${ }^{1}$ :

1. Eles buscam estabelecer relações entre os conteúdos científicos e os contextos conhecidos pelos estudantes.

2. Eles buscam, ao menos no campo do discurso, formar cidadãos críticos e conscientes.

\footnotetext{
${ }^{1}$ Embora aqui se trate apenas dos aspectos pedagógicos destes movimentos suas influências são muito mais amplas tendo repercussão no campo científico, tecnológico e político...
} 
3. Eles pressupõem a ocorrência de uma maior motivação e participação por parte dos estudantes nas aulas de ciências.

Sobre o primeiro ponto é importante notar que o nível de integração e dependência entre os contextos abordados e os conteúdos relacionados varia de acordo com a importância que se dá a um ou outro. A contextualização dos conteúdos, ou seja, o estabelecimento das relações práticas, conceituais e de juízo de valor entre contexto e conhecimento científico, pode ir desde uma simples exemplificação da aplicação de um dado conhecimento em um contexto do dia-a-dia até a exploração de um tema de relevância social onde os conhecimentos científicos são elementos decisivos na tomada de decisões e atitudes práticas individuais e coletivas.

O segundo ponto mostra uma tendência geral - não restrita ao campo da educação científica - de primar por uma formação escolar que vá além da transmissão para as novas gerações de um legado cultural construído e acumulado historicamente, mas também que possibilite aos estudantes-cidadãos agirem sobre a realidade que lhes está posta de forma consciente, autônoma e comprometida com valores éticos e morais compartilhados socialmente.

Finalmente, o terceiro ponto se refere à concepção partilhada por grande parte dos educadores e pesquisadores de que o ensino contextualizado promove uma participação mais ativa dos estudantes em decorrência da motivação despertada pelos temas abordados. Essa motivação é atribuída em geral aos seguintes elementos:

a) O aluno se sente motivado a estudar porque o tema faz parte de sua realidade social.

b) $O$ aluno se sente motivado porque o assunto mostra a importância do conhecimento científico e tecnológico para a sociedade e/ou para si mesmo.

c) O aluno se sente motivado porque a relação estabelecida entre contextos e conceitos facilita a aprendizagem destes.

Ao propor um ensino contextualizado, alguns professores procuram em geral motivar seus alunos para que possam estudar com mais afinco os conteúdos científicos, que em última análise, é o que realmente Ihes interessa. Essa concepção de contextualização foi denominada por Lutfi (1992) como "dourar a pílula".

Esse efeito motivador do ensino contextualizado tem sido observado por diversos pesquisadores ao redor do mundo ao avaliarem o uso de propostas de 
ensino CTS. Bennett et al. (2003) conduziram uma sistemática revisão de trabalhos científicos sobre ensino contextualizado de Ciências (38), Química (15), Física (9), Química e Física (1) e Biologia (3) de diversos países do mundo, sobretudo do EUA, Inglaterra, Holanda e Canadá. Eles apresentam como importantes resultados a existência de fortes evidências que suportam a posição de que (1) as abordagens contextualizadas motivam os estudantes nas aulas de ciências, (2) promovem atitudes mais positivas dos estudantes frente às ciências em geral e (3) não atrapalham a aprendizagem de idéias científicas por parte dos mesmos.

É esperado que essa maior disposição dos estudantes, decorrente da contextualização dos conteúdos científicos, resulte em um maior número de verbalizações e de interações entre os estudantes e entre estes e o professor. Podese questionar, por outro lado, se o fato de haver um maior número de verbalizações relacionadas ao conteúdo da aula resulta em desenvolvimentos de habilidades cognitivas de ordem alta. Em outras palavras, o que se questiona aqui é se o ensino contextualizado promove também o desenvolvimento das capacidades de pensar criticamente, raciocinar proporcionalmente, resolver novos problemas, transpor 0 conhecimento aprendido para novas situações etc., ou muda-se apenas a natureza das informações que se tem que memorizar.

Busca-se neste trabalho obter mais pistas que nos levem à formulação de uma resposta, mesmo que parcial, para esses questionamentos.

\section{2 - Revisão Bibliográfica:}

A seguir são apresentadas algumas investigações que buscaram compreender as interações em sala de aula. Este capítulo divide as investigações em dois grupos; pesquisas sobre as interações entre os alunos e pesquisas que investigam as interações entre professor e aluno.

\section{1 - Pesquisas sobre interações aluno-aluno: enfoque nas atividades em grupo}

A opção de muitos professores por trabalhar com grupos nas salas de aula se deve, em grande parte, ao fato de se acreditar que essa estratégia promova uma 
melhor aprendizagem dos conteúdos abordados. Esse aumento na aprendizagem, segundo algumas investigações, (LUMPE, 1995; RICHMOND; STRILEY, 1996; BIANCHINI, 1997; TOWNS et al., 2000) seria ocasionado por um aumento no grau de interações entre os pares, quantitativa e qualitativamente. Justifica-se, portanto, revisar algumas investigações que têm sido levadas a cabo sobre as interações entre estudantes em atividades desenvolvidas em grupos.

A dificuldade - ou mesmo impossibilidade - de coletar dados através de vídeo gravações em sala de aula com resolução de áudio que possibilitem uma análise detalhada das interações entre os alunos em aulas comuns (entenda-se por "aulas comuns" aulas sem atividades em grupos) leva muitos pesquisadores a optarem pelo registro das aulas em que os estudantes estejam trabalhando em atividades em grupo. Essa dificuldade se deve ao fato de, em situações comuns de aula, a dinâmica de comunicação entre os estudantes e entre estes e o professor ser muitas vezes caótica. Como registrar a fala de 30 ou 40 estudantes simultaneamente? Outro fator que favorece o registro das interações entre alunos em atividade em grupo é o fato de o favorecimento das interações sociais (causado a princípio pela simples proximidade física) promover, geralmente, uma maior interação verbal e cognitiva. Obviamente o fato de se juntar pessoas em um grupo não garante por si só que todos ali estejam engajados com a atividade.

Sobre a questão da estrutura de funcionamento dos grupos e do engajamento com a atividade, Johnson e Johnson (1981) propuseram a existência de três diferentes estruturas grupais:

Estrutura Cooperativa: Os objetivos dos participantes estão relacionados de tal forma que um indivíduo só pode alcançar seu objetivo se, e somente se, os outros membros do grupo alcançarem seus próprios objetivos. Assim, o objetivo do grupo se torna o objetivo de cada um.

Estrutura Competitiva: As ações de cada membro do grupo são de tal forma que quanto mais um indivíduo se aproxima do seu objetivo, mais distante os outros membros do grupo ficam de seus próprios objetivos.

Estrutura Individualista: Não existe correlação entre os objetivos dos membros do grupo, nem em sentido positivo, nem em sentido negativo.

Assim, mesmo que a atividade seja realizada em grupo, as interações verbais, sociais e cognitivas entre os indivíduos podem ser de diferentes naturezas e intensidades. 
Nas primeiras investigações sobre as diferenças na aprendizagem dos estudantes, buscava-se apenas conhecer em que situação se aprenderia melhor, individualmente ou em grupo (BARREIRO; ESCORZA, 2000). Entretanto, essa fase de "comprovação" da eficácia das atividades em grupo, segundo os autores, parece dar lugar nas últimas duas décadas a uma investigação mais aprofundada onde se busca desvendar os porquês dessa melhora na aprendizagem. Desta forma, as questões de investigação passaram de "Em que tipo de situação se aprende melhor, em atividades individuais ou em grupo?" para "Quais fatores promovem uma maior aprendizagem nas atividades em grupo?". Passou-se, então, a focalizar a análise do discurso em sala de aula como estratégia de investigação. Os autores destacam ainda o fato de que há um grande número de aproximações teóricas e técnicas que podem ser englobados pelo termo "cooperação em aula", indo desde a tutoria experiente-novato até a aprendizagem cooperativa, passando pela colaboração entre iguais.

Lonning (1993) investigou as interações verbais entre estudantes da $2^{\mathrm{a}}$ série do ensino médio com problemas de aprendizagem de ciências e analisou os efeitos das estratégias de aprendizagem cooperativa ${ }^{2}$ sobre as interações verbais dos estudantes ao longo das aulas sobre estrutura da matéria. Partindo do pressuposto que a aprendizagem se dá de forma mais efetiva quando os estudantes verbalizam suas idéias em interações com os colegas e professor, ele buscou categorizar e quantificar as falas dos estudantes.

Foi observado neste estudo que a estratégia de aprendizagem cooperativa fez com que aumentasse a freqüência das interações verbais entre os estudantes do grupo experimental (767/aula) quando comparado ao grupo de controle (467/aula). Entretanto, observou o pesquisador, a distribuição percentual das categorias de interações verbais permanece a mesma quando comparados os dois grupos. Segundo Lonning, embora a estratégia de aprendizagem cooperativa não tenha modificado a distribuição das categorias de interações verbais, pode-se concluir que

\footnotetext{
${ }^{2}$ Segundo Johnson e Johnson (apud Lonning, 1993), a aprendizagem cooperativa é baseada em cinco princípios:

1. Interdependência positiva: o sucesso individual depende do sucesso do grupo.

2. Interações face-a-face: os estudantes precisam interagir fisicamente e verbalmente para maximizar os benefícios dos grupos cooperativos.

3. Responsabilidade individual: o objetivo do ensino é que todos aprendam a matéria.

4. Habilidades interpessoais de pequenos grupos.

5. Processamento do grupo: feedbacks nas funções do grupo são necessários para encorajar melhorias.
} 
o aumento na quantidade total das interações verbais promoveu uma melhor aprendizagem no grupo experimental.

Um artigo bastante citado nos trabalhos sobre interações entre iguais é o de Kumpulainen e Mutanen (1999). Nesse artigo as pesquisadoras relatam a utilização de um sistema de análise das interações entre estudantes que trabalham em pequenos grupos. Esse instrumento consiste em uma série de categorias de interações divididas em três dimensões: funções das interações verbais ou lingüísticas, processos cognitivos e processos sociais. O sistema de análise descrito pelas pesquisadoras foi desenvolvido depois de uma série de estudos conduzidos com estudantes das séries primárias na Finlândia e Inglaterra. Elas afirmam que há a necessidade de se compreender o contexto social e situacional em que as interações verbais se dão. Para elas

As visões recentes sobre aprendizagem enfatizam sua natureza social e situacional, considerando a construção do conhecimento tanto um processo interpessoal como intrapessoal. Aprendizagem é vista como o resultado de um envolvimento individual ativo e a participação em situações sociais práticas e não o resultado da transmissão de conhecimento (p.451).

Além disso, as interações entre os estudantes são tratadas como um processo dinâmico em que a linguagem e outras ferramentas de significação são usadas como instrumentos de comunicação. As interações são vistas como fenômenos sociais complexos que são compostos por elementos não-verbais, verbais e sociais.

A análise das funções verbais das interações entre os estudantes focaliza os propósitos para os quais a linguagem verbal é usada em dado contexto. Em outras palavras, essa análise das funções verbais das interações desvenda as estratégias comunicativas aplicadas individualmente por cada estudante que participa da interação. A identificação das categorias de interação verbal foi baseada nas implicações e propósitos da fala, na interpretação das pesquisadoras. Essa interpretação foi necessária à categorização das interações verbais, pois aquilo que o falador diz pode ser diferente daquilo que foi literalmente dito. As funções de linguagem (categorias de interações verbais) que foram identificadas nas interações entre os estudantes foram: Informação, Exposição, Raciocínio, Avaliação, Interrogação, Resposta, Organização, Julgamento (concordância ou discordância), 
Argumentação, Composição (criar um texto), Revisão, Ditado, Leitura (em voz alta), Repetição e Experiência (expressar experiências pessoais).

Os processos cognitivos são os caminhos pelos quais os estudantes abordam as atividades de aprendizagem em sua atividade social. Elas destacam apenas 3 processos:

- Procedimental ou de Rotina: procedimentos relacionados à tarefa que focam o manuseio de objetos, organização e execução de atividades sem análise e reflexão.

- Interpretativo ou Exploratório: atividades críticas e exploratórias que incluem planejar, testar hipóteses, avaliar e realizar experimentos.

- Atividade Fora da Tarefa: atividades não relacionadas à tarefa.

$\mathrm{Na}$ dimensão dos processos sociais as autoras declaram que a análise tem os objetivos de caracterizar os relacionamentos sociais e os tipos de participação dos estudantes. São propostos os seguintes modos de interações sociais: colaboração, tutoria, argumentação, individualismo, domínio, conflito e confusão.

Nesse artigo é relatada a aplicação do método na análise das interações ocorridas em duas duplas de estudantes de 12 anos durante a realização de atividades de geometria. As aulas foram gravadas em áudio e vídeo e transcritas. Foram somados às transcrições dados de notas de campo. A partir dessas informações foram construídos mapas analíticos para cada grupo em investigação. Esses mapas mostram as falas dos estudantes ao longo do tempo e algumas informações sobre o contexto que fossem necessárias para a interpretação da atividade social em questão.

As pesquisadoras concluem o artigo dizendo que, embora o sistema analítico proposto e utilizado por elas careça de melhorias e adaptações em função das características dos sujeitos investigados, ele fornece uma poderosa ferramenta para compreender a dinâmica das interações entre os estudantes. Salientam, também, que conhecer esses diferentes mecanismos de interação entre os estudantes e cruzar essas informações com dados sobre idade, gênero, conhecimento prévio, tipos de atividades e outras variáveis possibilitariam o estabelecimento de pequenos grupos que levassem a uma aprendizagem mais efetiva.

Pesquisas sobre interação entre alunos também têm ocorrido no ensino universitário. Cordeiro et al. (2002) investigaram as interações sociais, cognitivas e lingüísticas vivenciadas por um grupo de estudantes de física no ensino 
universitário. Foram feitas gravações de vídeo e notas de campo nas aulas da unidade de termodinâmica e entrevistas com alunos de um grupo focal.

As questões de pesquisa foram: a) Quais são as características das interações entre alunos no trabalho em grupo? b) Quais são os padrões de interações (se existem) no funcionamento dos grupos de alunos? e c) Esses padrões variam de acordo com o tipo de tarefa proposta?

As pesquisadoras construíram um sistema de análise de interações em grupos de pares com base no sistema proposto por Kumpulainen e Mutanen (1999) para analisar os episódios selecionados na investigação. Segundo os resultados da investigação as pesquisadoras concluíram que:

- As diferentes tarefas propostas apresentaram um papel regulador dos processos sociais e cognitivos nas aulas, embora a análise dessas relações precise ainda ser aprofundada em pesquisas futuras.

- Na dimensão cognitiva foram detectadas situações de conflito cognitivo com a promoção de questionamentos, relativização e mudanças nas interpretações individuais sobre os fenômenos termodinâmicos.

- Mostrou-se também, na dimensão das interações sociais, uma estrutura cooperativa de funcionamento com alternâncias entre períodos de trabalho colaborativo e períodos de domínio de um membro do grupo sobre os demais.

As pesquisas aqui relatadas e as contribuições de outros trabalhos têm mostrado que as atividades em grupos resultam melhorias na qualidade das interações entre os estudantes e numa aprendizagem mais significativa dos conteúdos abordados. Mostram também que fatores como o ambiente da sala de aula, as atividades desenvolvidas, o conteúdo estudado e os papéis assumidos pelos membros do grupo são determinantes do tipo de interações que são estabelecidas.

A partir desses resultados pode-se levantar a questão: Quais fatores influem nas interações professor-aluno, no contexto da aula "comum"?

\section{2 - Pesquisas sobre interações professor-aluno}

Segundo Morge (2005) três principais vertentes têm constituído as investigações sobre as interações professor-aluno. Na primeira, o foco é posto sobre o discurso do professor e como esse pode afetar a aprendizagem dos alunos. A 
segunda vertente encara tanto professor quanto aluno como protagonistas da interatividade ao considerar igualmente suas falas. Neste caso pouca atenção é dada à dinâmica das interações, suas estruturas ou relação entre diferentes momentos da aula. A atenção é posta, sobretudo, no que professores e alunos dizem e não no porquê dessas declarações. Em geral esses estudos são quantitativos e buscam medir e relacionar a porcentagem de determinados padrões de falas com questões de gênero ou visão de ciência, por exemplo. A terceira vertente propõe não apenas conhecer os elementos das interações como também as relações entre estes, de modo a ter uma visão geral da estrutura da aula. Essas pesquisas geralmente são qualitativas.

Garrido (1996) conduziu uma investigação sobre a "qualidade do diálogo entre professor e alunos tendo em vista a mudança conceitual" (p.185). Para isto foram consideradas as sugestões pedagógicas de Posner et al. (1982) na aplicação de atividades elaboradas numa perspectiva construtivista sobre calor e temperatura. Foram investigadas as aulas de duas classes de Física da $2^{\mathrm{a}}$ série do ensino médio. As turmas tinham professoras diferentes, mas o material adotado e as atividades desenvolvidas eram os mesmos.

Para analisar as transcrições das aulas gravadas em vídeo foram construídas 20 categorias de análise das interações verbais baseadas no Modelo de Mudança Conceitual. As categorias foram divididas em falas do professor (11 categorias) e falas dos estudantes (9 categorias). As 11 categorias referentes às falas dos professores buscavam analisar as perguntas feitas para conhecer os modelos alternativos; as formas de organização do debate e encorajamento da participação; como se tentava provocar mudança conceitual; a crítica feita ao comportamento do aluno; a apresentação do conhecimento científico e outras formas de intervenção. As 9 categorias referentes às falas dos estudantes buscavam analisar como os estudantes respondem às questões; como eles pedem explicações ou manifestam falta de compreensão; como eles mudam ou reformulam seus conceitos alternativos; como eles fazem críticas às atividades; outras formas de intervenção e períodos de silêncio ou ruído.

A função do professor questionadora e encorajadora do debate e da investigação, que remonta a Sócrates, ganha aqui nova dimensão. Cabe ao professor estimular o pensamento cooperativo, engajando os alunos na busca de explicações para os fenômenos que os cercam. Ao tentarem explicar e explicitar as idéias tomam consciência de suas próprias 
concepções. Enriquecem-se com as colocações e argumentações dos companheiros. Cabe ao professor, sobretudo, a tarefa de promover o debate com o objetivo de ressaltar o confronto das opiniões com os dados ou a contradição entre diferentes pontos de vista, de modo a tornar o aluno intelectualmente insatisfeito com suas próprias concepções e aberto a elaboração de novas explicações ou à apresentação do modelo científico. A ruptura do aluno com a concepção ingênua do mundo requer que a classe seja um espaço em que os estudantes pensem e não simplesmente um espaço em que o professor informa sobre a visão de mundo dos cientistas.

A análise dos resultados da investigação mostrou que a professora $A$ usou $16 \%$ de suas intervenções na primeira aula propondo questões abertas (categoria $1)^{3}$ o que teria gerado $23,5 \%$ de falas dos alunos onde eles davam suas opiniões, propunham explicações ou justificativas (categoria 12) ${ }^{4}$. Quando ela usou menos questões abertas na $2^{\mathrm{a}}$ aula, apenas $6,7 \%$, ocorreu uma queda na participação dos estudantes na categoria 12 , com apenas $4,3 \%$ de suas falas.

A professora B usou de outra estratégia para motivar a participação dos alunos; ela investiu boa parte do tempo de aula valorizando as falas deles (categoria $3)^{5}$. Quando essa valorização diminui durante a $2^{\mathrm{a}}$ aula a participação dos estudantes também diminui. Esses resultados podem ser visualizados na tabela a seguir:

Tabela 2: Estratégia de duas professoras para aumentar a participação dos alunos nas aulas.

Valores dados em porcentagem de intervenções na aula. Adaptado de Garrido, 1996.

\begin{tabular}{|c|c|c|c|c|}
\hline \multirow{2}{*}{} & \multicolumn{2}{|c|}{ Professora A } & \multicolumn{2}{c|}{ Professora B } \\
\cline { 2 - 5 } & $\begin{array}{c}\text { A professora propõe } \\
\text { questões abertas } \\
\text { (categoria 1) }\end{array}$ & $\begin{array}{c}\text { Os alunos dão } \\
\text { opiniões e } \\
\text { explicações } \\
\text { (categoria 12) }\end{array}$ & $\begin{array}{c}\text { A professora valoriza } \\
\text { as respostas dos } \\
\text { alunos (categoria 3) }\end{array}$ & $\begin{array}{c}\text { Os alunos dão } \\
\text { opiniões e explicações } \\
\text { (categoria 12) }\end{array}$ \\
\hline $1^{\text {a } \text { Aula }}$ & 16 & 23,5 & 25 & 13 \\
\hline $2^{\text {a } \text { Aula }}$ & 6,7 & 4,3 & 10 & 6,5 \\
\hline
\end{tabular}

A partir desses dados pode-se inferir que ao menos dois fatores apresentam uma correlação positiva com a participação dos estudantes quanto à emissão de opiniões pessoais, explicações e justificativas: o uso de questões abertas e a valorização da fala dos alunos.

\footnotetext{
${ }^{3} \mathrm{Na}$ categoria 1 a professora questiona os modelos alternativos dos alunos por meio de questões abertas do tipo "O que você acha?"; "Como a chama aquece a chaleira?"; "Você tem outra explicação?".

4 Na categoria 12 os alunos respondem questões dando suas opiniões, tentando explicá-las ou justificá-las.

${ }^{5} \mathrm{Na}$ categoria 3 a professora encoraja a participação da turma ao usar, esclarecer e relacionar as idéias dos alunos ou apreciar suas colocações.
} 
Apesar do bom índice de verbalizações dos alunos apresentado durante as duas aulas analisadas - entre 14 e $38 \%$ das falas totais -, parece não ter havido uma mudança conceitual (categorias 16 e 17$)^{6}$ considerável nos estudantes. Esse insucesso quanto ao ganho cognitivo, segundo a pesquisadora, parece ter relação com a ausência ou o pouco uso de questões metacognitivas (categoria 4$)^{7}$ e de desequilíbrio cognitivo (categoria 5$)^{8}$ por parte das professoras.

Uma fala de um aluno reproduzida no texto da autora chama a atenção para uma questão importante e que muitas vezes é ignorada por alguns educadores que optam por abordagens diferenciadas como o ensino para mudança conceitual ou mesmo o ensino contextualizado, aspecto que não é discutido no texto, mas que pode ser considerado aqui sem grandes riscos.

A2: Nós já estamos discutindo faz quatro aulas um negócio que a gente não entende absolutamente nada. Então, finalmente, a gente vê um filme. Acontece que a gente continua como estava no começo. Não há mais nada a dizer. Precisamos de informação para poder continuar [trecho extraído da transcrição da fala de um aluno (GARRIDO, 1996, p.197)].

As colocações do aluno A2 ilustram de forma excepcional uma concepção deturpada de ensino construtivista partilhada por muitos professores: a idéia de que o conhecimento é construído pelo aluno simplesmente pela reflexão sobre seus próprios conhecimentos. Partindo desse falso pressuposto, têm-se observado aulas em que os professores realizam debates ou propõe outras atividades para explorar as concepções iniciais dos estudantes e esperam que, através disto, eles cheguem à formulação de conceitos científicos, sem que sejam fornecidos outros elementos que subsidiem essa construção. Não se atenta para o fato que as idéias iniciais dos estudantes tanto podem constituir matéria-prima para a formulação de novos conhecimentos - ponto considerado fundamental no MMC e no ensino contextualizado - quanto podem se tornar obstáculos a ela. É preciso superar essa concepção ingênua de construtivismo que tem prejudicado professores e alunos na

\footnotetext{
${ }^{6}$ Na categoria 16 os alunos evidenciam suas mudanças conceituais ao dar explicações mais inteligíveis, plausíveis, consistentes tentando superar as críticas. Na categoria 17 eles usam ou aplicam adequadamente o conhecimento científico.

${ }_{7}^{7}$ Nesta categoria o professor tenta provocar mudança conceitual ao levantar questões metacognitivas para que os estudantes reexaminem seus argumentos, procurando torná-los mais inteligíveis, mais convincentes ou mais frutíferos.

8 Nesta categoria o professor tenta provocar mudança conceitual ao propor questões conflitivas que ressaltam o confronto entre as opiniões dos alunos e os fatos, ou a contradições entre diferentes pontos de vista.
} 
execução de propostas educativas voltadas para mudança conceitual ou contextualização. O professor precisa, sim, explorar as idéias iniciais dos estudantes, mas também fornecer informações que Ihes possibilite avançar em direção a compreensão do mundo que os rodeia. É preciso encontrar o meio termo entre o "falar tudo" do modelo de educação por transmissão cultural e "falar nada" dessa perspectiva ingênua de construtivismo.

De Longhi (2000) investigou as interações entre professor e alunos em aulas de ciências. A pesquisadora tinha como objetivo propor um esquema de análise que permitisse descrever, interpretar e explicar as seqüências de diálogos que eram gerados nas aulas de ciências e destinados ao ensino de determinados temas. A elaboração das categorias de análise "se realizaram através de um processo de teorização que culminou com o desenvolvimento de uma tipologia ou classificação" (p.206). Dentre as conclusões obtidas pela pesquisadora, a partir das análises dos dados, pode-se ressaltar:

- Quanto à questão da autoridade: A relação entre os processos de ensino e aprendizagem é assimétrica quanto às funções do professor e do aluno "porque é o professor que desencadeia e orienta a participação do aluno", sendo a posição do professor substancialmente e preponderantemente predominante. "Na elaboração conjunta do conhecimento, o docente regula o ritmo e o tempo de construção, que nem sempre contempla as possibilidades do aluno, fazendo valer sua autoridade tanto acadêmica quanto funcional" (p.204).

- Quanto ao conteúdo: "O caráter do conteúdo é outro dos elementos que influem no processo de comunicação, não só pela forma que se faz explícito na aula, mas também pela implicação disciplinar, lógica particular, seleção e organização curricular, grau de formalização, distanciamento do conhecimento cotidiano e conhecimentos prévios relacionados. Assim, um conteúdo mais próximo da experiência dos alunos favorece a dinâmica de interação na aula e possibilita a participação dos estudantes" (p.205).

Santos et al. (2001) destacam a importância da construção de contextos argumentativos nas aulas de ciências. Ao investigar a capacidade de argumentação dos estudantes nas aulas de ciências onde eram realizados debates sobre aspectos sócio-científicos, os pesquisadores concluíram que as dificuldades apresentadas pelos estudantes estão relacionas tanto à complexidade do conteúdo abordado quando à capacidade do professor em conduzir o diálogo. 
Todavia, deve-se considerar que não só a complexidade do assunto foi um fator limitante, mas também a própria dificuldade do professor em conduzir os debates no sentido de discutir a natureza dos argumentos (p. 149).

Para os pesquisadores é necessário que os professores comecem a questionar seus alunos durante as aulas fazendo intervenções para que expliquem o que sabem com maior riqueza de detalhes para que esse processo de interação dialogada vá além da motivação e do reconhecimento da importância da argumentação.

\section{3 - Metodologia}

Apresento a seguir algumas reflexões sobre as questões metodológicas da pesquisa. Aqui fundamento a opção por uma abordagem qualitativa interpretativa, defino os sujeitos da pesquisa, explico como se deu a coleta de dados e finalmente abordo a questão mais complexa da metodologia desta investigação, a análise dos dados.

\section{1 - Metodologia de pesquisa}

Quanto à metodologia de pesquisa este trabalho de investigação se enquadra em um estudo de casos numa abordagem qualitativa interpretativa (ANDRÉ, 2000).

O objeto de estudo desta investigação, as interações em sala de aula, prescinde de uma abordagem que possibilite uma compreensão ampla e ao mesmo tempo detalhada da realidade vivenciada por professores e alunos nos processos interativos de ensino e aprendizagem. Assim, o uso exclusivo de técnicas de coleta de dados fora do contexto de sala de aula, tais como entrevistas com professores e alunos, questionários ou análise de documentos, não seria adequado. Era preciso captar na íntegra a realidade da sala de aula com toda sua complexidade e riqueza de informações. Por esse motivo optei por gravar em áudio e vídeo as aulas investigadas. A questão da coleta de dados é discutida com maiores detalhes mais adiante, no tópico 3.2.1. 
A impossibilidade de se reproduzir o estudo tal qual ele foi realizado por estar baseado em situações e contextos reais - provavelmente únicos - dificulta a discussão da fidedignidade externa dos resultados. Entretanto é possível analisar a fidedignidade interna, ou seja, a medida da concordância de múltiplos pesquisadores sobre os dados recolhidos e resultados obtidos (ANDRÉ, 2000). Isto se fez nesta pesquisa mediante a colaboração de pesquisadores experientes (1 professor doutor e 2 mestres da área de ensino de ciências) e de alguns pares (6 mestrandos em ensino de ciências) que analisaram os dados obtidos, aplicaram as categorias de análise aos dados, discutiram os pontos divergentes e sugeriram alterações no instrumento de análise ao longo de 6 horas de discussões em grupo divididas em três encontros nos meses de abril e maio de 2006.

$\mathrm{Na}$ avaliação da validade dos resultados obtidos, ou seja, na medida em que esses resultados se aproximam da realidade da sala de aula, deve-se considerar o fato de que, como foi dito anteriormente, a sala de aula é algo complexo e mutável de modo que qualquer instrumento de análise que se proponha aplicar aos dados dessa realidade complexa e mutável só possibilitará um panorama parcial dela. A despeito do empenho e dedicação postos na construção do instrumento de análise, o qual será detalhado a partir do tópico 3.2, alguns aspectos que poderiam ser considerados importantes por outros pesquisadores ou em outras investigações foram inevitavelmente deixados de lado. É isso o que aconteceu, por exemplo, com a questão do gênero, do aspecto social e afetivo das interações ou dos materiais didáticos envolvidos nas aulas analisadas. Assim, pode-se dizer que a aplicação do instrumento de análise aos dados obtidos através das gravações das aulas forneceu resultados válidos, sim, mas que representam apenas alguns aspectos da realidade que se propôs investigar, quais sejam, as interações verbais e cognitivas estabelecidas entre os professores e alunos em aulas onde o conhecimento químico é contextualizado.

\subsection{1 - Sujeitos da Pesquisa}

Como a investigação se propunha a olhar para as interações entre professores/objetos de conhecimento/alunos nas aulas de química em que houvesse contextualização dos conhecimentos científicos - não importando que visões de contextualização tenham os professores - a escolha dos sujeitos da pesquisa não 
poderia ser aleatória. Era preciso que na aula a ser analisada houvesse um mínimo de interação entre os alunos e o professor e que o conteúdo da aula versasse, ao menos em alguns momentos, sobre assuntos ligados à vivência cotidiana ou ao conhecimento da sociedade que se imagina ter estes alunos.

Cabe aqui esclarecer que a designação "sujeitos da pesquisa" atribuída aos professores é um tanto quanto imperfeita. Essa imperfeição deve-se ao fato de o objeto de pesquisa desta investigação não ser "a ação docente de ensinar" em si mesma, mas o processo interativo de ensino-aprendizagem estabelecido diálogo entre os alunos e o professor em sala de aula. Em outras palavras atribuir ao professor o título de sujeito da pesquisa é meramente o cumprimento de uma convenção, se assim pode-se dizer, não representando em nada uma pretensa superioridade dos papéis desempenhados pelos professores em detrimento da contribuição dos estudantes. O papel dos estudantes não é menos importante de forma alguma nesse processo interativo de ensino aprendizagem. Esse foco sobre a fala do professor e a desvalorização das contribuições dos estudantes já tem sido alvo de críticas de alguns pesquisadores e tem sido superado nos últimos anos.

Assim, os professores teriam de ser escolhidos de forma intencional de modo a propiciarem em suas aulas certo grau de interação com os alunos na mediação entre estes e o conhecimento científico. Assim, a escolha dos sujeitos da pesquisa foi baseada nos seguintes critérios:

- Os professores deveriam ser Licenciados em Química e lecionar a disciplina Química;

- Os professores deveriam declarar em uma avaliação informal de triagem que utilizam em suas aulas a contextualização dos conhecimentos científicos;

- Os professores deveriam permitir a vídeo-gravação de algumas de suas aulas, sendo estas em turmas em que, segundo o próprio professor, não houvesse problemas de indisciplina que prejudicassem o andamento da aula.

Satisfeitos esses critérios, foi combinado e agendado com os professores a gravação das aulas. Foram gravadas em vídeo 3 aulas, sendo duas delas de uma professora de uma escola estadual da cidade de Mauá, aqui denominada de professora A, e 1 aula de outra professora da cidade de Carapicuíba, denominada professora B. Ambas as escolas estão situadas na periferia dessas cidades que fazem parte da Grande São Paulo. 


\subsection{2 - Registro dos dados e transcrições}

Como foi mencionado anteriormente, a contextualização dos conteúdos científicos tem sido uma opção freqüente de alguns educadores por considerarem que ela resulta em uma maior participação dos estudantes nas aulas, maior motivação para os estudos e maior número de verbalizações ao longo da aula. Para conhecer de forma mais aprofundada as interações entre professores, alunos e os objetos de conhecimentos é necessário o uso de uma técnica de coleta de dados que capte o maior número de informações possíveis sobre o clima social e afetivo da turma, as expressões corporais e faciais de quem fala, a dinâmica das interações e, sobretudo, a exata expressão oral usada pelos sujeitos nas interações. Assim, a coleta de dados foi realizada a partir de gravações em vídeo das aulas das professoras pelo próprio pesquisador. A câmera foi posicionada sobre uma carteira escolar - sem tripé - no fundo da sala no centro ou no canto para se obter uma imagem ampla de toda a sala e ao mesmo tempo não intimidar os alunos (a câmera posta de frente para os alunos poderia intimidá-los e inibir sua participação na aula). As aulas foram gravadas na íntegra, incluindo períodos de silêncio, tumulto e organização da sala e das atividades. Tanto os professores quanto os alunos se mostraram bastante à vontade com a câmera e com a presença do pesquisador na sala, fazendo poucas referências a isso no decorrer das aulas e parecendo agir naturalmente - o que inclui manifestações positivas tais como se concentrar na atividade e interagir com a professora e manifestações negativas como falar palavrões e fazer brincadeiras inoportunas.

Uma dificuldade corrente enfrentada por quem investiga a sala de aula é saber como coletar dados dos quais se possam abstrair informações pertinentes para a resolução das questões de pesquisa propostas. Mesmo que se opte por fazer gravações em vídeo, a quantidade de informações pertinentes que podem ser perdidas pode ser muito grande. É praticamente impossível ter uma captação de áudio perfeita devido às inúmeras interferências causadas pelas vozes dos estudantes mesmo em aulas onde não haja problemas de indisciplina. Às vezes, a própria participação dos estudantes nas discussões atrapalha a coleta de dados; preferir uma aula onde impere o silêncio dos alunos, sobressaindo apenas a voz do professor, não nos serve; e esperar que os alunos participem ativamente das discussões de forma ordeira, sem interromper as falas uns dos outros, sem falar uns 
sobre os outros, cada um esperando pacientemente com o dedinho erguido sua vez de falar é simplesmente utopia. A imagem captada pela câmera de vídeo também é limitada. Muitas informações importantes sobre a aula são perdidas por escaparem às lentes da câmera.

Assim, ao mesmo tempo em que as aulas eram gravadas, foram feitas também notas de campo para registrar informações que servissem ao entendimento da complexa realidade da aula, quais sejam: impressões sobre o clima social da turma, falas inaudíveis dos professores e alunos, ocorrência de atividades desligadas da aula, engajamento dos estudantes nas tarefas etc. Essas notas de campo serviram como fontes de dados para ampliar a compreensão das interações entre os professores e os alunos. Elas foram consultadas durante a transcrição das aulas e na composição do mapa analítico.

As gravações foram transcritas pelo próprio pesquisador para garantir maior fidedignidade das transcrições em relação aos registros obtidos. Apesar dos cuidados tomados quanto à qualidade das gravações e seleção dos professores e turmas, algumas perdas foram inevitáveis. A maioria das falas dos estudantes dirigida aos professores e vice-versa pôde ser transcrita facilmente, todavia, as falas entre os estudantes não eram audíveis em sua maioria.

\section{2 - Metodologia de análise dos dados}

Os dados obtidos a partir das observações, registrados nas notas de campo, e as gravações foram analisados considerando que estes, por si só, não possuem valor se não forem interpretados à luz das informações do contexto social sobre o qual eles foram criados. Esse contexto social é criado nas interações entre os professores e alunos, sendo sujeito a uma infinidade de variáveis sobre as quais se tem pouco controle. Isto torna a realidade da sala de aula algo mutável e, por isso, de difícil interpretação. Como afirma Moreira (1990):

A sala de aula, por exemplo, é vista como um ambiente organizado social e culturalmente, no qual ações mudam constantemente, significados são adquiridos, trocados, compartilhados. Naturalmente, o contexto assume então um papel de destaque, pois os significados e as ações são contextuais. A pesquisa 
interpretativa procura analisar criticamente cada significado em cada contexto (p.33).

Assim, em termos práticos, o significado de cada interação deve ser abstraído considerando as informações do contexto em que ela está inserida. Uma mesma fala pode apresentar significados diferentes - e até mesmo opostos - dependendo do contexto em que foi gerada.

Cada fala foi enquadrada em uma das categorias de análise da dimensão verbal e em outra da dimensão cognitiva de acordo com o que foi proposto no instrumento de análise dos dados, sempre se levando em conta as informações de seu contexto de origem.

\subsection{1 - Interações cognitivas de Alta e de Baixa Ordem}

As interações cognitivas podem ter diferentes níveis de complexidade, exigindo um grau maior ou menor de abstração ou de estabelecimento de relações conceituais ou lógico-matemáticas com uma quantidade também variável de elementos. Em outras palavras, pode-se dizer que as atividades mentais realizadas pelos estudantes na busca pela compreensão de um conceito, na resolução de um problema ou na tomada de uma decisão podem envolver diferentes níveis de complexidade. O mesmo pode ser pensado para o professor em seu ato de ensinar. O discurso construído pelo professor ao explicar determinado conceito pode exigir dele e de seus alunos um pensamento com maior ou menor grau de elaboração.

Esses níveis de elaboração mental podem envolver a mobilização de funções mentais de complexidade variável, mas é importante destacar, aqui, que todos esses processos, por mais simples e elementares que possam parecer, são necessários. A memorização de uma definição por parte de um estudante em estágio de aprendizagem de um conceito ou a evocação dessa memória, quando solicitada por uma questão dada pelo professor, constituem, pois, exemplos de atividades mentais de baixo nível de elaboração. Entretanto, pode-se considerar essa etapa de memorização como um estágio ainda embrionário da compreensão daquele conceito. O estudante, mediante processos de reflexão e de estabelecimento de relações conceituais com seu conhecimento já acumulado pode vir a assimilar o conceito, integrando-o em sua estrutura conceitual já estabelecida. 
Assim, processos mentais simples, tais como memorizar, evocar a memória, propor questões fechadas, repetir, concordar/discordar sem justificar ou a aplicação direta de uma fórmula matemática (algoritmo) também têm seu papel no ensino. $\mathrm{O}$ problema ocorre quando o ensino é voltado preponderantemente para o exercício desses processos mentais.

Zoller (1993) tem contribuído para a educação em Química (e nas demais ciências também) ao propor como referência que se prime pelo desenvolvimento de Habilidades Cognitivas de Alta Ordem (Higher Order Cognitive Skills - HOCS) em detrimento do desenvolvimento apenas das Habilidades Cognitivas de Baixa Ordem (Lower Order Cognitive Skills - LOCS). As habilidades cognitivas de alta ordem (HOCS), pela definição do autor, incluem as capacidades de formular questões, solucionar problemas (não exercícios) e tomar decisões, além do desenvolvimento de um sistema de pensamento crítico. O pensamento crítico é visto como um pensamento avaliativo racional, lógico, reflexivo e 'conseqüencial' (que considera as conseqüências futuras), seguido de uma decisão e uma ação responsável coerente. Por outro lado, as LOCS estariam relacionadas, sobretudo, à aquisição de informações e uso de algoritmos (ZOLLER, 1993).

O autor admite também que o conjunto de habilidades consideradas de alta ordem cognitiva pode variar de acordo com o educador (ou com o pesquisador, pode-se inferir).

Sobre essa subjetividade no delineamento das habilidades cognitivas, Stamovlasis et al. (2005) fazem algumas observações com relação às questões apresentadas aos estudantes em exames, mas que podem ser estendidas para outras situações:

a. Vários autores têm usado métodos diversos para categorizar questões como sendo de algoritmos ou como conceituais.

b. Questões conceituais têm sido relacionadas com HOCS e questões de algoritmo com LOCS.

c. O grau em que uma questão é categorizada como conceitual, até certo ponto, é dependente dos conhecimentos prévios do estudante e do tipo de ensino a que ele está sendo exposto nas aulas.

Assim, uma questão que requer HOCS para um estudante pode precisar apenas de LOCS para outro estudante ou em outra situação. 
Essas mesmas considerações podem ser aplicadas para outras situações que não as questões de uma prova, como por exemplo, o diálogo entre professor e aluno em sala de aula. É plausível, então, considerar que:

$\checkmark$ as interações em sala de aula podem exigir dos estudantes diferentes níveis de demanda cognitiva dependendo, basicamente, de dois fatores:

- o nível de elaboração da fala do professor e

- os conhecimentos prévios dos estudantes.

$\checkmark$ a classificação dessas interações como sendo de alta ou baixa ordem cognitiva, embora possa ter elementos mais consensuais no meio acadêmico, depende, em última instância, do pesquisador e daquilo que ele considera como sendo um pensamento muito ou pouco elaborado para a situação em estudo.

As categorias de interações que se descrevem a seguir para a dimensão cognitiva foram classificadas como sendo de alta ou baixa ordem. As interações cognitivas de alta ordem envolvem uma maior demanda intelectual, 0 estabelecimento de relações conceituais e/ou numéricas entre diversos elementos, a concatenação de várias idéias simples na composição de um pensamento mais complexo e a possibilidade de respostas múltiplas. As interações cognitivas de baixa ordem, por outro lado, envolvem uma pequena demanda intelectual, o fornecimento de informações pontuais e o não estabelecimento de relações entre essas informações.

Embora essa classificação seja discutível ela é necessária. Seria uma incoerência maior ainda colocar em um mesmo patamar de elaboração intelectual interações que demandem 'esforços mentais' tão diferentes quanto se lembrar de um nome e propor uma analogia. O engajamento intelectual é tão diferente nesses dois exemplos que seria impossível considerá-los como tendo o mesmo grau de importância.

\subsection{2 - Dimensões e Categorias de análise}

A realidade complexa da sala de aula por um lado dificulta a compreensão das interações entre professor e aluno, sendo parte dessa dificuldade atribuída ao caráter mutável da sala de aula. Nenhuma aula é igual à outra. Mesmo que se 
investigue a mesma sala de aula durante semanas, cada aula será diferente uma da outra, pois os elementos que constituem a aula se modificam constantemente. $\mathrm{O}$ conteúdo muda, as estratégias de ensino mudam, a disposição do professor para ensinar e dos alunos para aprender muda e até mesmo um aluno que vem ou que falta à aula pode interferir drasticamente no clima da sala.

Por outro lado, essa realidade complexa também possibilita uma diversidade de olhares sobre a aula. É praticamente infindável a quantidade de questõesproblema que podem ser investigadas nas aulas. Esta investigação se propôs a conhecer as interações entre professores e alunos em aulas de Química onde o conteúdo é contextualizado, sendo essas interações analisadas em duas diferentes dimensões: verbal e cognitiva.

A dimensão social não foi contemplada de forma explícita neste trabalho por dois motivos: ela se constitui como pano de fundo para a interpretação das interações dos sujeitos e ela já vem sendo largamente explorada na literatura, quase sempre com enfoque nas questões afetivas ou referentes às interações entre alunos em atividades com grupos colaborativos.

A dimensão verbal diz respeito àquilo que é expresso oralmente nas interações entre professores e alunos. Busca conhecer os tipos de questões formuladas e os tipos de respostas dadas a essas questões; busca também conhecer as outras manifestações orais possíveis dentro do contexto de uma aula, tais como leitura, ditado, feedback, transmissão de informação, convite à participação, repetição, afirmação e orientação para organizar a disposição física da sala ou de uma atividade.

Na dimensão verbal o olhar é posto mais sobre a forma do que é falado do que sobre as intenções, conteúdo ou significado do que é falado. De certa maneira, pode-se compreender a dimensão verbal como uma pré-analise daquilo que é falado, como um primeiro olhar, uma análise ainda preliminar e superficial da fala dos sujeitos.

Ao mesmo tempo em que esse olhar superficial pode ser criticado pela falta de detalhamento sobre o que é falado, ele também possibilita a abstração de importantes informações sobre a aula como um todo. Isso porque um olhar profundo também implica, quase sempre, em um olhar restrito. Saber, por exemplo, quem questiona mais durante as aulas, o professor ou o aluno, ou se são freqüentes os feedbacks depois das respostas dos estudantes possibilitaria também adquirir 
informações importantes sobre a dialogicidade da aula ou sobre a importância dada pelo professor às contribuições dos alunos.

Já a dimensão cognitiva diz respeito aos processos mentais que estão por trás das falas dos sujeitos; detém-se nos propósitos, conteúdos e significados daquilo que é expresso oralmente.

A análise das interações na dimensão cognitiva complementa e aprofunda a reflexão sobre as falas dos sujeitos.

Falas que, quanto à forma, são iguais - questões, por exemplo - podem ser extremamente diferentes quanto aos processos mentais que desencadeiam no questionado quando ele mobiliza seus conhecimentos e habilidades cognitivas na busca de uma resposta. Uma questão fechada que busque como resposta apenas a citação de um nome ou fórmula como, por exemplo, "Qual a fórmula da água?" produz uma demanda cognitiva diferente de uma questão como "Por que a fórmula da água é $\mathrm{H}_{2} \mathrm{O}$ e não $\mathrm{HO}_{2}$ ?". Talvez você, leitor, tenha respondido de pronto a primeira questão enunciada acima - " $\mathrm{H}_{2} \mathrm{O}$, é claro!" -, mas certamente teve que refletir mais para responder a segunda questão, ou ainda esteja pensando na resposta, ou pior ainda, não tem condições de respondê-la neste momento por mais que se esforce.

O exemplo dado para a fórmula química da água ilustra o que acontece com as demais formas de interações: elas podem requerer diferentes demandas cognitivas por parte de quem fala - na sua elaboração - e de quem ouve - na busca de compreensão do que foi ouvido e na construção de uma nova fala. Para distinguir esses níveis de demanda cognitiva, as categorias de interações dessa dimensão foram divididas em dois conjuntos, como mencionado no tópico anterior: interações cognitivas de baixa ordem e interações cognitivas de alta ordem.

As categorias de análise tanto da dimensão cognitiva quanto da verbal foram construídas considerando-se quatro elementos fundamentais.

1 - Referenciais Teóricos. Como foi mencionado na seção 1.3, a análise das interações em sala de aula deve considerar que as falas dos alunos numa discussão têm um caráter de coletividade, na medida em que diferentes vozes são consideradas pelo professor na elaboração de seu discurso - muitas vezes como sendo de um mesmo interlocutor -, mas também de individualidade, de forma que não se pode afirmar que um conhecimento construído por "n" vozes tenha sido também compreendido pelos mesmos " $\mathrm{n}$ " indivíduos. Questiona-se aqui a noção - 
tão amplamente disseminada - de "construção coletiva de conhecimento", que, a meu ver, carece de maior reflexão. Outro ponto também importante que foi considerado na metodologia desta pesquisa foi a opção por construir as categorias de análise a posteriori, e não a partir de um "deve ser" marcado pelos modelos pedagógicos do pesquisador (CANDELA, 1998).

2 - Pesquisas Anteriores. São muitos os trabalhos de investigação publicados em revistas científicas de educação em ciências que tratam da questão das interações em sala de aula. Essas investigações apresentam uma grande diversidade de enfoques, tais como o uso de questões, a argumentação científica, atividades em grupos e o discurso do professor, tendo provido uma compreensão ampla do tema. Grande parte dessas pesquisas apresentava um grupo de categorias de análise para as interações investigadas. Essas categorias contribuíram para a constituição das categorias de análise apresentadas neste trabalho. Algumas delas foram incorporadas aqui praticamente sem modificações, ao passo que outras foram reformuladas, unidas ou desconsideradas na medida em que se tentou sintetizar o conhecimento adquirido durante a revisão bibliográfica. Aquelas pesquisas que não apresentavam categorias de análise bem estruturadas mostraram, por outro lado, uma análise qualitativa interpretativa que também foi interessante e útil. Não foi encontrado nenhum trabalho de pesquisa, durante a revisão bibliográfica, que investigasse as interações cognitivas e verbais entre professores e estudantes em aulas onde o conhecimento científico era contextualizado.

3 - Análise Preliminar dos Dados. Considerando-se as categorias de interações verbais e cognitivas encontradas na literatura e uma primeira leitura do registro transcrito de uma aula da professora $A$, foi feita uma versão provisória do instrumento de análise, as categorias de análise. Esse instrumento foi aplicado ao registro, desta vez de forma mais estruturada, construindo um mapa analítico da aula. Nesse mapa analítico as falas dos alunos e da professora A foram categorizados quase sempre nas duas dimensões. Pouquíssimas falas não puderam ser categorizadas na aplicação do instrumento de análise, sendo deixados em branco os espaços referentes à sua categorização. Isso equivale à existência de uma categoria "outros", que englobaria todas as outras manifestações verbais e cognitivas não contempladas pelo instrumento de análise. 
4 - Discussões com os Colaboradores. Após a aplicação do instrumento de análise e de uma primeira reformulação deste, os registros transcritos da aula e as categorias de análise já reformuladas foram oferecidos a alguns colegas mestres e mestrandos do Programa de Pós-Graduação em Ensino de Ciências - Modalidade Química da Universidade de São Paulo que generosamente aceitaram o convite para colaborar com esta investigação. Esses colegas aplicaram o instrumento de análise nos registros transcritos da mesma aula da professora $A$, sendo que isso se deu ao longo de três encontros semanais de duas horas cada. No primeiro encontro foi realizada uma apresentação inicial da pesquisa, dos dados obtidos e do instrumento de análise mais ou menos em meia hora de conversa. Após essa apresentação inicial cada colaborador recebeu o material (registros transcritos da aula e instrumento de análise). Nesse encontro foi realizada uma discussão conjunta sobre o material e também uma primeira aplicação das categorias de análise aos registros com o objetivo de que os colaboradores se familiarizassem com o material e sanassem as dúvidas referentes aos significados de cada categoria de análise. Nesse encontro foram categorizadas as interações dos quatro primeiros episódios da aula, que está dividida em um total de oito. Sugestões foram feitas pelos colaboradores e, no mesmo encontro, pequenas alterações foram realizadas no instrumento. Solicitou-se aos colaboradores que cada um individualmente e em sua casa aplicasse o instrumento aos outros quatro episódios restantes para posterior discussão. Os outros dois encontros foram dedicados à discussão da aplicação do instrumento de análise aos registros de aula e à proposição de modificações nas categorias de análise através de reformulações, subtração de algumas categorias e introdução de outras. Vale ressaltar que os colaboradores estavam familiarizados, ao menos em parte, com alguns dos referenciais teóricos aqui adotados e com algumas pesquisas sobre interações em sala de aula devido a discussões de artigos científicos que vinham ocorrendo a alguns meses dentro do mesmo grupo.

As categorias de análise propostas dentro de cada dimensão estão na tabela 3 e 4, a seguir. Nessa tabela são mostrados os códigos de cada categoria de análise usados para classificar as falas das professoras e dos alunos. 
Tabela 3: Categorias de análise da dimensão cognitiva das interações em sala de aula.

\begin{tabular}{|c|c|c|c|}
\hline \multicolumn{2}{|r|}{ Categoria } & Código & Descrição \\
\hline \multirow{9}{*}{ 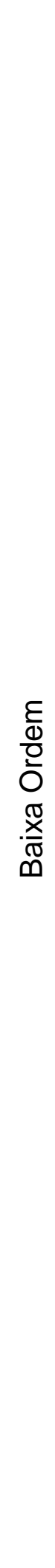 } & Questão retórica & QR & $\begin{array}{l}\text { Questão feita para organizar o próprio } \\
\text { pensamento, sem que haja a intenção } \\
\text { de que alguém a responda. }\end{array}$ \\
\hline & $\begin{array}{l}\text { Questão de } \\
\text { confirmação }\end{array}$ & QC & $\begin{array}{l}\text { Questão para avaliar se a última } \\
\text { informação dada foi assimilada pelo } \\
\text { ouvinte. Geralmente usa-se de questões } \\
\text { curtas, do tipo "Você entendeu?" ou } \\
\text { "Alguma dúvida?" }\end{array}$ \\
\hline & Questão fechada & QF & $\begin{array}{l}\text { Questão que apresenta apenas uma ou } \\
\text { poucas respostas corretas. São } \\
\text { questões que buscam como resposta } \\
\text { informações e não uma opinião pessoal } \\
\text { ou uma explicação. }\end{array}$ \\
\hline & Resposta descritiva & RD & $\begin{array}{l}\text { Descreve um fenômeno ou objeto; } \\
\text { apresenta as características observadas } \\
\text { sem a explicação do fato. }\end{array}$ \\
\hline & $\begin{array}{l}\text { Resposta } \\
\text { informativa }\end{array}$ & RI & $\begin{array}{l}\text { Uma informação específica como, por } \\
\text { exemplo, o nome de uma substância, a } \\
\text { classificação de um ácido ou a definição } \\
\text { de um conceito. }\end{array}$ \\
\hline & Complete & $\mathrm{CP}$ & $\begin{array}{l}\text { Inicia-se uma frase para que alguém a } \\
\text { complete. Tem função e valor cognitivo } \\
\text { semelhantes à questão fechada. }\end{array}$ \\
\hline & Discordância & DIS & $\begin{array}{l}\text { Apresenta uma divergência de idéias. } \\
\text { Geralmente são frases curtas e sem } \\
\text { justificativa. }\end{array}$ \\
\hline & Concordância & CON & $\begin{array}{l}\text { Apresenta uma convergência de idéias. } \\
\text { Geralmente são frases curtas e sem } \\
\text { justificativa. }\end{array}$ \\
\hline & Revisão & REV & Relembra idéias vistas anteriormente. \\
\hline
\end{tabular}




\begin{tabular}{|c|c|c|c|}
\hline & Exemplificação & EX & $\begin{array}{l}\text { Seleção de um exemplo como resposta } \\
\text { de uma questão, como ilustração de } \\
\text { uma idéia ou demonstração da } \\
\text { aplicação de um conceito. }\end{array}$ \\
\hline & Paráfrase & PAR & $\begin{array}{l}\text { Tradução de uma idéia com outras } \\
\text { palavras para demonstrar entendimento. }\end{array}$ \\
\hline & Informação & INF & $\begin{array}{l}\text { Exposição de teorias, dados ou regras } \\
\text { sem prévio requerimento. }\end{array}$ \\
\hline & Reformulação & REF & $\begin{array}{l}\text { Refazer uma idéia, conciliar ou negociar } \\
\text { significados em busca de uma idéia } \\
\text { mais correta. }\end{array}$ \\
\hline \multirow{5}{*}{$\begin{array}{l}\frac{\varepsilon}{d} \\
\frac{0}{0} \\
\frac{\pi}{0} \\
\frac{\pi}{4}\end{array}$} & Questão aberta & QA & $\begin{array}{l}\text { Questão que possibilita diversas } \\
\text { respostas ou diferentes formas de se } \\
\text { respondê-la. Geralmente referem-se a } \\
\text { explicações de fenômenos. }\end{array}$ \\
\hline & $\begin{array}{l}\text { Questão de } \\
\text { desequilíbrio }\end{array}$ & QD & $\begin{array}{l}\text { Questão feita para que o questionado } \\
\text { reflita, amplie ou reformule uma } \\
\text { resposta dada a outra questão ou idéia } \\
\text { apresentada por ele. Pode ser uma } \\
\text { questão do tipo aberta como "Por quê?" } \\
\text { ou um pedido de esclarecimento como } \\
\text { "Justifique sua resposta!" }\end{array}$ \\
\hline & Questão subjetiva & QS & $\begin{array}{l}\text { Questão que busca saber a opinião } \\
\text { pessoal do questionado. Não há } \\
\text { resposta certa ou errada. }\end{array}$ \\
\hline & $\begin{array}{l}\text { Resposta } \\
\text { explicativa }\end{array}$ & $\mathrm{RE}$ & $\begin{array}{l}\text { Composição de idéias para elaborar } \\
\text { uma explicação de um fenômeno. }\end{array}$ \\
\hline & $\begin{array}{l}\text { Síntese, resumo ou } \\
\text { generalização }\end{array}$ & SIN & $\begin{array}{l}\text { Junção de diferentes informações para } \\
\text { a composição de uma idéia mais } \\
\text { complexa ou abrangente. Resumo das } \\
\text { idéias anteriormente discutidas. }\end{array}$ \\
\hline
\end{tabular}




\begin{tabular}{|l|l|l|l|}
\hline Análise & ANLS & $\begin{array}{l}\text { Decomposição de uma idéia complexa } \\
\text { ou abrangente em fragmentos mais } \\
\text { simples. }\end{array}$ \\
\hline Hipótese & HIP & $\begin{array}{l}\text { Levantamento de uma teoria provável, } \\
\text { uma suposição admissível. }\end{array}$ \\
\hline Analogia & ANLG & $\begin{array}{l}\text { Explicação de uma idéia complexa } \\
\text { através de uma comparação com outras } \\
\text { coisas de fácil compreensão. }\end{array}$ \\
\hline Juízo de valores & JV & $\begin{array}{l}\text { Avaliação e tomada de posção } \\
\text { embasada nos conhecimentos } \\
\text { adquiridos, na moral e na ética. }\end{array}$ \\
\hline
\end{tabular}

Tabela 4: Categorias de análise da dimensão verbal das interações em sala de aula.

\begin{tabular}{|l|l|l|}
\hline \multicolumn{1}{|c|}{ Categoria } & Código & \multicolumn{1}{|c|}{ Descrição } \\
\hline Questionamento & Q & Proposição de uma questão. \\
\hline Resposta & R & $\begin{array}{l}\text { Informação dada em decorrência de } \\
\text { uma questão. }\end{array}$ \\
\hline Feedback & FB & $\begin{array}{l}\text { Avaliação de uma resposta. Pode ser } \\
\text { tanto positivo, confirmando uma } \\
\text { resposta correta, quanto negativo. }\end{array}$ \\
\hline Ditado & D & $\begin{array}{l}\text { Pronúncia de algo com objetivo de que o } \\
\text { ouvinte escreva o que foi dito. }\end{array}$ \\
\hline Repetição & REP & $\begin{array}{l}\text { Repetição da fala de outro. Não } \\
\text { apresenta função cognitiva de grande } \\
\text { valor. Usa-se geralmente para } \\
\text { demonstrar atenção e valorização da } \\
\text { fala do outro (função afetiva). }\end{array}$ \\
\hline Leitura & L & $\begin{array}{l}\text { Leitura de texto ou outra linguagem } \\
\text { simbólica tal como gráfico ou tabela } \\
\text { (sem interpretação). }\end{array}$ \\
\hline Afirmação & AF & $\begin{array}{l}\text { Fazer uma declaração ou dar uma } \\
\text { informação. }\end{array}$ \\
\hline
\end{tabular}




\begin{tabular}{|l|l|l|} 
Organização & O & $\begin{array}{l}\text { Informação para organizar/ordenar uma } \\
\text { atividade ou o grupo. }\end{array}$ \\
\hline Convite & C & $\begin{array}{l}\text { Chamada para a participação na aula } \\
\text { através de uma opinião, comentário ou } \\
\text { resposta. }\end{array}$ \\
\hline
\end{tabular}

\subsection{3 - Mapas analíticos}

Os mapas analíticos são tabelas onde são organizadas as informações sobre as interações entre o professor e os alunos. Neles constam as seguintes informações: de quem é a fala, descrição detalhada da fala, informações gerais (ambiente da sala, gestos e entonação de voz), categoria da interação na dimensão verbal, categoria de interação de baixa e alta ordem na dimensão cognitiva. Esses mapas foram elaborados com três principais propósitos: fornecer elementos mais detalhados sobre as interações de modo a subsidiar a análise interpretativa; possibilitar a quantificação das interações e identificar padrões de interações.

Os mapas também estão divididos em episódios de interações. Cada aula foi dividida em episódios para facilitar sua análise. O critério adotado para a divisão dos episódios foi o conteúdo abordado pela professora. Embora a divisão da aula em episódios pareça um tanto quanto "artificial", pois a aula é um todo em que cada momento está intimamente relacionado com os anteriores, essa fragmentação é um mal necessário. Poder-se-ia optar por outros critérios tais como as atividades desenvolvidas pelos alunos ou as estratégias de ensino do professor. Mas foi preferível dividir a aula em função do conteúdo abordado pelo professor, já que o objetivo era analisar as interações cognitivas estabelecidas entre os sujeitos ao se engajarem na tentativa de ensinar e aprender conteúdos científicos tratados dentro de contextos de estudo socialmente significativos. Em outras palavras, pode-se dizer que as falas do professor e dos alunos são arquitetadas com uma intencionalidade quase sempre bem definida e que gira em torno do ensino e da aprendizagem do conteúdo. Trata-se, portanto, de inferir sobre o que está por trás da fala. Quando se percebe na fala dos sujeitos, sobretudo do professor, que há a intenção de mudar o conteúdo que está sendo abordado, muda-se também de episódio. 
As categorias de análise foram aplicadas às interações frase por frase. Muitas vezes a fala do sujeito é composta por uma seqüência de frases que pode variar muito quanto à quantidade de frases e ao tipo de interação que se busca estabelecer. Em uma única fala podem existir, por exemplo, questões retóricas, uma analogia e uma afirmação. As possibilidades de combinações são simplesmente infinitas.

Algumas vezes percebe-se que uma dada interação de alta ordem cognitiva que exige uma elaboração mental maior se prolonga ou repercute numa seqüência de interações. Por exemplo, o professor para contextualizar um conteúdo ou construir uma analogia com o objetivo de ensiná-lo precisaria usar de uma diversidade de outras formas de interações mais simples de baixa ou alta ordem cognitiva. Analisando uma dessas falas isolada de seu contexto não se percebe a contextualização ou a construção da analogia, mas quando a seqüência é observada como um todo, fica evidenciado que a intenção de quem fala vai além daquilo que a frase diz em si mesma. Ela faz parte de um construto mais amplo e ambicioso. Assim, essa interação mais complexa teria uma repercussão ao longo de uma seqüência de falas e interações mais simples.

\subsection{4 - Análise qualitativa interpretativa}

Os mapas analíticos foram analisados de maneira qualitativa interpretativa. Isto significa que durante a análise dos mapas são consideradas as falas dos sujeitos de forma a abstrair delas seu conteúdo, propósitos (explícitos e implícitos) e significados, e a freqüência das categorias de interações verbais e cognitivas encontradas.

A freqüência em que cada categoria de análise aparece é reportada em termos de números de ocorrências, o que não vai contra a proposta metodológica de um estudo qualitativo interpretativo. Como afirma André (2000, p. 24), "o número ajuda a explicar a dimensão qualitativa" em nada descaracterizando a abordagem qualitativa da investigação. Segundo a autora, há um mal entendido sobre as diferenças entre pesquisa qualitativa e quantitativa por parte de alguns investigadores. É comum que considerem que a pesquisa qualitativa é simplesmente "uma pesquisa que não envolve números", o que seria uma visão ingênua ou deturpada da pesquisa qualitativa. 
A partir das leituras realizadas durante a revisão bibliográfica e da reflexão inicial sobre as aulas gravadas, foram selecionados alguns pontos para serem analisados a cada episódio das interações entre os professores e alunos por considerá-los de maior relevância para a compreensão da aula. Trata-se apenas de um guia semi-estruturado da análise interpretativa, que servirá para orientar a análise das interações e não para limitá-la. Os pontos selecionados foram:

- Quem verbaliza mais;

- Quem propõe as questões;

- Quais tipos de questões e respostas são mais freqüentes;

- Como se distribui o uso de Interações Cognitiva de Alta e Baixa Ordem;

- Como é feita a relação entre o conhecimento científico e o conhecimento tecnológico, social, ambiental ou cotidiano.

A partir da análise dos mapas analíticos buscar-se-á: (a) construir um panorama geral das interações verbais e cognitivas entre as professoras e os alunos, (b) compreender como essas interações favorecem a construção do conhecimento e (c) propor relações entre a contextualização do conhecimento e as interações estabelecidas nas aulas.

\section{4 - Análise das aulas}

As transcrições das aulas das professoras A e B foram analisadas aplicandose as categorias elaboradas no instrumento de análise (tabelas 3 e 4). De forma geral, cada frase foi enquadrada em uma categoria da dimensão verbal e uma da dimensão cognitiva. As aulas são divididas em episódios, como foi explicado anteriormente. Cada episódio constitui uma unidade de análise que é analisada de forma qualitativa interpretativa considerando-se tanto a freqüência de ocorrência das categorias quanto os pontos de interesse apresentados no item 3.2.4.

Deve-se frisar que foram gravadas um total de 10 aulas sendo elas de 4 professores, mas 7 dessas aulas não serviram para a pesquisa por não se enquadrar no perfil de aula desejado. Buscou-se registrar aulas em que o professor estabelecesse relações entre os conhecimentos científicos e a sociedade, tecnologia, vida cotidiana, problemas ambientais etc., ou seja, uma aula contextualizada, dentro das diversas perspectivas possíveis. Essas aulas 
descartadas não apresentavam qualquer forma de contextualização, mesmo através de exemplos, que é o nível de contextualização mais elementar. Essas aulas foram gravadas porque na etapa de triagem os professores atendiam aos requisitos abordados no item 3.1.1 da metodologia de pesquisa, mas, infelizmente, as aulas registradas não eram contextualizadas. Assim, as três aulas aqui analisadas foram ministradas por duas professoras, denominadas A e B e apresentam algum nível de contextualização.

\section{1 - Aulas da Professora A}

Foram gravadas duas aulas da professora A. Na primeira delas a discussão gira em torno do assunto poluição atmosférica e na segunda aula fala-se sobre nomenclatura de óxidos. Essas aulas foram gravadas numa turma do $2^{\circ}$ ano do Ensino Médio, no período diurno. A escola está localizada em um bairro da periferia da cidade de Mauá. O prédio da escola apresentava excelente estado de conservação e limpeza. A turma era formada por alunos com idades entre 15 e 16 anos e muitos deles usavam o uniforme da escola. A sala de aula era arrumada e limpa e as carteiras estavam dispostas em fileiras duplas, indicando que, na maioria do tempo, os estudantes trabalhavam em duplas.

\section{Episódio 1 da aula 1 da professora A (E1A1PA)}

\begin{tabular}{|c|c|c|c|c|c|c|}
\hline \multicolumn{7}{|c|}{ E1A1PA: Conceituação de "Poluição e poluente atmosférico" } \\
\hline \multirow[t]{2}{*}{ Turno } & \multirow{2}{*}{$\begin{array}{l}\text { Quem } \\
\text { fala? }\end{array}$} & \multirow[t]{2}{*}{ Descrição detalhada das falas } & \multirow{2}{*}{$\begin{array}{c}\text { Observações } \\
\text { contexto }\end{array}$} & \multirow{2}{*}{$\begin{array}{c}\text { Interação } \\
\text { verbal }\end{array}$} & \multicolumn{2}{|c|}{$\begin{array}{l}\text { Interação } \\
\text { cognitiva }\end{array}$} \\
\hline & & & & & B.O. & A.O. \\
\hline 1 & $\mathrm{P}$ & $\begin{array}{l}\text { Nós vamos estar fazendo uma } \\
\text { discussão das questões sobre } \\
\text { poluição atmosférica, que é o } \\
\text { tema desse bimestre. E nós } \\
\text { vamos estar verificando aquilo } \\
\text { que vocês já sabem. Sim? }\end{array}$ & $\begin{array}{l}\text { enfatiza a } \\
\text { expressão } \\
\text { "já sabem" }\end{array}$ & $\begin{array}{l}\mathrm{O} \\
\mathrm{Q}\end{array}$ & QC & \\
\hline 2 & $P$ & $\begin{array}{l}\text { Então, vamos lá. Primeiro: O que } \\
\text { vocês entendem por poluente } \\
\text { atmosférico? }\end{array}$ & $\begin{array}{l}\text { lê a questão } \\
1 \text { que havia } \\
\text { sido escrita } \\
\text { na lousa }\end{array}$ & Q & & QA \\
\hline
\end{tabular}




\begin{tabular}{|c|c|c|c|c|c|c|c|}
\hline 3 & $\mathrm{P}$ & Alesson. & & $\begin{array}{l}\text { convida um } \\
\text { aluno a } \\
\text { responder }\end{array}$ & C & & \\
\hline 4 & A & Fumaça (...) & a & & $\mathrm{R}$ & EX & \\
\hline 5 & $\mathrm{P}$ & $\begin{array}{l}\text { O que você entende por poluição } \\
\text { atmosférica? }\end{array}$ & $\square$ & & $\mathrm{Q}$ & & QA \\
\hline 6 & A & $(\ldots)$ & $\square$ & & & & \\
\hline 7 & $\mathrm{P}$ & $\begin{array}{l}\text { Não é isso, Alesson. O que você } \\
\text { entende? }\end{array}$ & $\square$ & $\begin{array}{l}\text { enfatiza } \\
\text { "você } \\
\text { entende" }\end{array}$ & $\begin{array}{l}\mathrm{FB} \\
\mathrm{Q}\end{array}$ & DIS & QS \\
\hline 8 & A & Corta! & a & risos & & & \\
\hline 9 & $A^{\prime}$ & $(\ldots)$ & $\square$ & & & & \\
\hline 10 & $A^{\prime \prime}$ & $\begin{array}{l}\text { É a poluição através de produtos } \\
\text { tóxicos, das substâncias tóxicas } \\
\text { das fábricas (...) }\end{array}$ & $\square$ & & $\mathrm{R}$ & $\mathrm{RI}$ & \\
\hline 11 & $P$ & O que mais? & $\square$ & & REP & & \\
\hline 12 & $A^{\prime \prime \prime}$ & $\begin{array}{l}\text { É a fumaça de ônibus, dos } \\
\text { carros... }\end{array}$ & $\square$ & & $\mathrm{R}$ & EX & \\
\hline 13 & $P$ & Boa! & $\square$ & & FB & CON & \\
\hline 14 & A & Poluentes químicos. & a & & $\mathrm{R}$ & $\mathrm{RI}$ & \\
\hline 15 & $P$ & Poluentes químicos. & & $\begin{array}{l}\text { repete a fala } \\
\text { de um aluno }\end{array}$ & REP & & \\
\hline 16 & $P$ & O que mais? & $\square$ & & REP & & \\
\hline 17 & A & Os gases do enxofre. & a & & $\mathrm{R}$ & EX & \\
\hline 18 & $A^{\prime}$ & Substâncias tóxicas. & a & & $\mathrm{R}$ & $\mathrm{RI}$ & \\
\hline 19 & $\mathrm{P}$ & Substâncias tóxicas. & & $\begin{array}{l}\text { repete a fala } \\
\text { de um aluno }\end{array}$ & REP & & \\
\hline 20 & $\mathrm{P}$ & O que mais? & a & & REP & & \\
\hline 21 & A & $(\ldots)$ & a & & & & \\
\hline 22 & $P$ & Que gases? & a & & $\mathrm{Q}$ & QF & \\
\hline 23 & A & Quais são os gases? & a & & REP & & \\
\hline 24 & $A^{\prime}$ & $(\ldots)$ & a & & & & \\
\hline 25 & $P$ & $\begin{array}{l}\text { E quais são os poluentes que } \\
\text { vocês conhecem? }\end{array}$ & $\square$ & $\begin{array}{l}\text { lê a } \\
\text { segunda } \\
\text { questão da } \\
\text { lousa }\end{array}$ & Q & QF & \\
\hline 26 & $A$ & Gases de enxofre. & a & & $\mathrm{R}$ & $\mathrm{RI}$ & \\
\hline 27 & $A^{\prime \prime}$ & Óxidos de nitrogênio. & a & & $\mathrm{R}$ & $\mathrm{RI}$ & \\
\hline 28 & A"' & Gás carbônico. & $\square$ & & $\mathrm{R}$ & $\mathrm{RI}$ & \\
\hline
\end{tabular}




\begin{tabular}{|c|c|c|c|c|c|c|c|}
\hline 29 & $P$ & $\begin{array}{l}\text { Gases de enxofre, óxidos de } \\
\text { nitrogênio, gás carbônico }\end{array}$ & & $\begin{array}{l}\text { repete as } \\
\text { falas dos } \\
\text { alunos }\end{array}$ & REP & & \\
\hline 30 & A & Nitrogênio, nitrogênio. & a & risos & $\mathrm{R}$ & $\mathrm{RI}$ & \\
\hline 31 & $\mathrm{~A}^{\prime}$ & $\begin{array}{l}\text { Dióxido de enxofre; óxidos de } \\
\text { nitrogênio }\end{array}$ & $\square$ & $\begin{array}{l}\text { tumulto, } \\
\text { muitos } \\
\text { respondem } \\
\text { ao mesmo } \\
\text { tempo }\end{array}$ & $\mathrm{R}$ & $\mathrm{RI}$ & \\
\hline 32 & $P$ & $\begin{array}{l}\text { Dióxido de enxofre, óxidos de } \\
\text { nitrogênio. }\end{array}$ & $\square$ & $\begin{array}{l}\text { repete as } \\
\text { falas dos } \\
\text { alunos }\end{array}$ & REP & & \\
\hline 33 & $A$ & O que sai do carro. & a & & $\mathrm{R}$ & $\mathrm{RI}$ & \\
\hline 34 & $\mathrm{P}$ & O que sai do carro. & & $\begin{array}{l}\text { repete a fala } \\
\text { de um aluno }\end{array}$ & REP & & \\
\hline 35 & A & $(\ldots)$ & a & & & & \\
\hline 36 & $\mathrm{P}$ & $\begin{array}{l}\text { Todos esses são poluentes } \\
\text { atmosféricos. Pessoal, lembra } \\
\text { quando a gente falou o que é } \\
\text { poluição? O que é? }\end{array}$ & a & & $\begin{array}{l}\mathrm{AF} \\
\mathrm{Q} \\
\mathrm{Q}\end{array}$ & $\begin{array}{l}\text { QF } \\
\text { QF }\end{array}$ & SIN \\
\hline 37 & A & $(\ldots)$ & a & & & & \\
\hline 38 & $P$ & $\begin{array}{l}\text { Não. Quando você fala em } \\
\text { poluição... quando é considerado } \\
\text { poluição? }\end{array}$ & u & & $\begin{array}{l}\mathrm{FB} \\
\mathrm{Q}\end{array}$ & DIS & QA \\
\hline 39 & A & $(\ldots)$ & a & & $\mathrm{R}$ & $\mathrm{RI}$ & \\
\hline 40 & $P$ & Quando polui. & & $\begin{array}{l}\text { repete a fala } \\
\text { de um aluno }\end{array}$ & REP & & \\
\hline 41 & $P$ & $\begin{array}{l}\text { Lembra daquela história da árvore } \\
\text { e suas folhas? }\end{array}$ & a & & $\mathrm{Q}$ & $\begin{array}{c}\text { REV } \\
\text { QF }\end{array}$ & \\
\hline 42 & A & Não... & a & & $\mathrm{R}$ & $\mathrm{RI}$ & \\
\hline 43 & $\mathrm{P}$ & $\begin{array}{l}\text { Pessoal, quando eu falei da } \\
\text { história da árvore quando caem } \\
\text { as folhas no bosque. É uma } \\
\text { poluição? }\end{array}$ & $\square$ & & $\begin{array}{l}\mathrm{AF} \\
\mathrm{Q}\end{array}$ & $\begin{array}{l}\text { INF } \\
\text { QF }\end{array}$ & \\
\hline 44 & A & Não. & $\square$ & & $\mathrm{R}$ & $\mathrm{RI}$ & \\
\hline 45 & $P$ & Por que? & a & & Q & & QD \\
\hline 46 & $P$ & $\begin{array}{l}\text { Não tá no ambiente natural, não } \\
\text { tá? Se eu jogo aquelas folhas no } \\
\text { quintal de vocês? }\end{array}$ & $\square$ & & $\begin{array}{l}\mathrm{AF} \\
\mathrm{Q} \\
\mathrm{Q}\end{array}$ & $\begin{array}{l}\text { INF } \\
\text { QR } \\
\text { QF }\end{array}$ & \\
\hline
\end{tabular}




\begin{tabular}{|c|c|c|c|c|c|c|c|}
\hline 47 & A & | Eu vou brigar com a senhora! & ם & risos & & & \\
\hline 48 & $\mathrm{P}$ & É considerado poluição? & a & & Q & QF & \\
\hline 49 & A & Não. & a & & $\mathrm{R}$ & $\mathrm{RI}$ & \\
\hline 50 & $A^{\prime}$ & É. & a & & $\mathrm{R}$ & $\mathrm{RI}$ & \\
\hline 51 & $\mathrm{P}$ & No seu quintal?! & & $\begin{array}{l}\text { aponta para } \\
\text { o aluno que } \\
\text { disse "não" }\end{array}$ & Q & & QD \\
\hline 52 & $A^{\prime}$ & É. & a & & $\mathrm{R}$ & $\mathrm{RI}$ & \\
\hline 53 & $\mathrm{P}$ & $\begin{array}{l}\text { Por que? Porque não está em seu } \\
\text { ambiente natural. Então quando } \\
\text { você tem uma substância que não } \\
\text { está no seu ambiente natural ou } \\
\text { não está na quantidade natural, } \\
\text { está em excesso, é considerado } \\
\text { poluente. }\end{array}$ & & $\begin{array}{l}\text { faz pergunta } \\
\text { retórica }\end{array}$ & $\begin{array}{l}\mathrm{Q} \\
\mathrm{AF}\end{array}$ & QR & SIN \\
\hline 54 & $\mathrm{P}$ & $\begin{array}{l}\text { Será que no ar não existe gás } \\
\text { carbônico? }\end{array}$ & $\square$ & & Q & QF & \\
\hline 55 & A & Existe, existe, sim. & a & & $\mathrm{R}$ & $\mathrm{RI}$ & \\
\hline 56 & $P$ & $\begin{array}{l}\text { E as fábricas e os automóveis } \\
\text { lançam gás carbônico, e ele é } \\
\text { considerado poluente? }\end{array}$ & a & & $\begin{array}{c}\mathrm{AF} \\
\mathrm{Q}\end{array}$ & $\begin{array}{l}\text { INF } \\
\text { QF }\end{array}$ & \\
\hline 57 & A & Sim. & a & & $\mathrm{R}$ & $\mathrm{RI}$ & \\
\hline 58 & $\mathrm{P}$ & Por que? & a & & Q & QF & \\
\hline 59 & A & Porque está em maior quantidade. & a & & $\mathrm{R}$ & & $\mathrm{RE}$ \\
\hline 60 & $A^{\prime}$ & Em excesso. & a & & $\mathrm{R}$ & & $\mathrm{RE}$ \\
\hline 61 & $\mathrm{P}$ & $\begin{array}{l}\text { Em excesso, uma grande } \\
\text { quantidade. Quando você tem um } \\
\text { excesso, aí eu tenho ele como um } \\
\text { poluente, porque está em } \\
\text { excesso. }\end{array}$ & D & $\begin{array}{l}\text { repete as } \\
\text { falas dos } \\
\text { alunos }\end{array}$ & $\begin{array}{l}\text { REP } \\
\text { AF }\end{array}$ & & SIN \\
\hline
\end{tabular}

Obs.: (...) Representa trechos da gravação inaudíveis. Alguns foram caracterizados por inferência devido às observações de contexto e, principalmente, a repetição das falas feita pela professora.

Nesse episódio a professora A parece ter como objetivos discutir com os estudantes o que eles sabem sobre os termos 'poluição' e 'poluente atmosférico' e conduzí-los à formalização desses termos. Para tanto, a professora faz uma série de questões aos estudantes buscando obter informações primeiramente sobre o que eles saberiam sobre o tema poluição. Nesse início, não parece haver o objetivo de 
formação de conceito e sim de levantamento das idéias prévias dos estudantes ou dos conhecimentos já adquiridos em aulas anteriores. São usadas tanto questões abertas (3) quanto questões fechadas (11). As respostas dadas pelos estudantes foram respostas curtas e pouco elaboradas e quase sempre informativas, ou seja, informam o nome de um poluente ou dizem apenas 'sim' ou 'não', sem justificá-las. Dentre as 22 respostas fornecidas pelos estudantes 17 foram informativas e as outras foram exemplos (3) ou respostas explicativas (2).

Entre as fala 36 e 40 a professora A questiona os estudantes sobre as condições necessárias para caracterizar a ocorrência de poluição em um ambiente qualquer. Como não recebeu respostas adequadas para as questões, ela recorre, primeiro, a uma rápida contextualização do problema proposto (Saber em que condições um material é considerado como poluente), entre as falas 41-53, e, depois, à aplicação dessas condições em um exemplo real, a presença de gás carbônico na atmosfera, entre as falas 54-61. Entre as falas 41-53 a professora aborda um exemplo que fora mencionado em aulas anteriores, onde se contrapunha a presença de folhas de árvores em um bosque (um ambiente comum a elas) e no quintal dos estudantes. O quintal dos estudantes é considerado, naquele momento, como um ambiente estranho ou inadequado para a presença das folhas de árvores. Parece que a professora tinha a intenção de que a contraposição dessas duas situações levasse seus alunos à compreensão da presença de determinados materiais em ambientes que não lhes são naturais ocasiona o que se chama de poluição. Ela buscou conduzir o diálogo através de uma seqüência de questões de modo que os estudantes chegassem à conceituação correta do termo poluente. No final do diálogo ela acaba fazendo uma síntese das idéias abordadas e aplica a conceituação ao problema real do excesso de gás carbônico na atmosfera.

Ambos os exemplos podem ser considerados como tentativas de estabelecer uma contextualização do conteúdo estudado por irem além da mera citação das situações como exemplos ou aplicações do conteúdo estudado, como poderia ter ocorrido. O fato de a professora A ter explorado por alguns instantes esses dois exemplos fazendo com que os estudantes refletissem sobre eles e expusessem suas idéias aumentou consideravelmente o valor formativo dessas situações. Nesses trechos a professora propôs questões abertas, elaborou sínteses e os alunos deram respostas explicativas - além de muitas outras respostas informativas 
- o que mostra um bom engajamento intelectual por parte da professora e dos estudantes na discussão especificamente nesse trecho do episódio.

Tabela 5: Distribuição das interações Verbais e Cognitivas em E1A1PA

\begin{tabular}{|c|c|c|c|c|c|}
\hline \multirow{2}{*}{\multicolumn{2}{|c|}{ Interações verbais }} & \multicolumn{4}{|c|}{ Interações Cognitivas } \\
\hline & & \multicolumn{2}{|c|}{ Ordem Baixa } & \multicolumn{2}{|c|}{ Ordem Alta } \\
\hline Categorias & $\mathrm{N}^{\circ}$ de ocorrências & CAT. & $\mathrm{N}^{\circ}$ DE OC. & CAT. & $\mathrm{N}^{\circ}$ DE OC. \\
\hline $\mathrm{Q}$ & 20 & $\mathrm{RI}$ & 17 & QA & 3 \\
\hline $\mathrm{R}$ & 22 & QF & 11 & SIN & 3 \\
\hline REP & 11 & INF & 3 & $\mathrm{RE}$ & 2 \\
\hline AF & 6 & EX & 3 & QD & 2 \\
\hline FB & 3 & QR & 2 & QS & 1 \\
\hline $\mathrm{O}$ & 1 & DIS & 2 & & \\
\hline C & 1 & QC & 1 & & \\
\hline & & CON & 1 & & \\
\hline & & REV & 1 & & \\
\hline Total & 64 & total & 41 & total & 11 \\
\hline
\end{tabular}

Pelos dados apresentados na Tabela 5 pode-se perceber que as interações verbais nesse episódio ocorreram, sobretudo, através de muitas questões (20) e respostas (22). Percebe-se também o uso principalmente de questões fechadas (11) e, em menor escala, de questões abertas (3), sendo as respostas em sua maioria informativas (17).

As questões feitas nesse episódio foram sempre propostas pela professora e a participação dos estudantes ficou limitada a respondê-las. Apesar da boa participação dos estudantes em termos de quantidade de falas (31), elas foram curtas e pouco elaboradas. Provavelmente isso tenha ocorrido devido ao pequeno uso, por parte da professora, se comparado às outras formas de interação empregadas, de questões abertas de desequilíbrio e subjetivas.

Assim, como observado por Garrido (1996), a professora buscou valorizar as falas dos alunos possivelmente para motivar a participação da turma na aula. Ela repete as respostas dos estudantes como sinal de que está atenta às respostas deles e que as valoriza. Ela não julga as respostas de imediato, apenas as aceita, provavelmente para que os outros alunos que ainda não deram sua opinião se sintam à vontade em fazê-lo. Provavelmente essa estratégia foi em parte responsável pela boa participação dos estudantes nesse episódio. 
Houve, contudo, poucas interações cognitivas de alta ordem (11) em relação às interações cognitivas de baixa ordem (41). As interações cognitivas de alta ordem quase sempre partiram da professora.

\section{Episódio 2 da aula 1 da professora A (E2A1PA)}

\begin{tabular}{|c|c|c|c|c|c|c|}
\hline \multicolumn{7}{|c|}{ E2A1PA: Conseqüências da Poluição atmosférica } \\
\hline \multirow[t]{2}{*}{ Turno } & \multirow{2}{*}{$\begin{array}{l}\text { Quem } \\
\text { fala? }\end{array}$} & \multirow[t]{2}{*}{ Descrição detalhada das falas } & \multirow{2}{*}{$\begin{array}{c}\text { Observações } \\
\text { contexto }\end{array}$} & \multirow{2}{*}{$\begin{array}{c}\text { Interação } \\
\text { verbal }\end{array}$} & \multicolumn{2}{|c|}{$\begin{array}{l}\text { Interação } \\
\text { cognitiva }\end{array}$} \\
\hline & & & & & O.B. & O.A. \\
\hline 1 & $P$ & $\begin{array}{l}\text { E aqui? Quais são as } \\
\text { conseqüências da poluição } \\
\text { atmosférica para o ser humano... } \\
\text { O que causa? }\end{array}$ & $\begin{array}{l}\text { lê a questão } \\
3 \text { na lousa }\end{array}$ & $\begin{array}{l}\mathrm{Q} \\
\mathrm{Q}\end{array}$ & QR & QA \\
\hline 2 & A & Doenças de pele. (...) & $\begin{array}{l}\text { muitos } \\
\text { respondem } \\
\text { ao mesmo } \\
\text { tempo }\end{array}$ & $\mathrm{R}$ & $\mathrm{RI}$ & \\
\hline 3 & $\mathrm{P}$ & Doenças respiratórias. & $\begin{array}{l}\text { repete a fala } \\
\text { de um aluno }\end{array}$ & REP & & \\
\hline 4 & $A^{\prime}$ & Pulmonares. & 口 & $\mathrm{R}$ & $\mathrm{RI}$ & \\
\hline 5 & A & De pele, câncer de pele. & $\begin{array}{l}\text { o aluno } \\
\text { insiste }\end{array}$ & $\mathrm{R}$ & $\mathrm{RI}$ & \\
\hline 6 & $\mathrm{P}$ & De pele. Alergias. & $\begin{array}{l}\text { repete a fala } \\
\text { de um aluno }\end{array}$ & REP & & \\
\hline 7 & A" & Laringite. & a & $\mathrm{R}$ & RI & \\
\hline 8 & A & De pele $(\ldots)$ & u insiste & REP & & \\
\hline 9 & $P$ & Os olhos. Irritação nos olhos. & $\begin{array}{l}\text { repete a fala } \\
\text { de um aluno }\end{array}$ & REP & & \\
\hline 10 & $P$ & O que mais? & $\square$ & REP & & \\
\hline 11 & A & $(\ldots)$ & a & & & \\
\hline 12 & $P$ & $\begin{array}{l}\text { Tudo isso são problemas para a } \\
\text { saúde do ser humano. Sim? O } \\
\text { que que causa problemas para o } \\
\text { meio ambiente? }\end{array}$ & $\square$ & $\begin{array}{c}\mathrm{AF} \\
\mathrm{Q} \\
\mathrm{Q}\end{array}$ & QC & $\begin{array}{l}\text { SIN } \\
\text { QA }\end{array}$ \\
\hline 13 & A & Causa, sim. & $\square$ & $\mathrm{R}$ & RI & \\
\hline 14 & $A^{\prime}$ & As queimadas. (...) & $\square$ & $\mathrm{R}$ & $\mathrm{RI}$ & \\
\hline 15 & $\mathrm{P}$ & Plantas. & $\begin{array}{l}\text { repete a fala } \\
\text { de um aluno }\end{array}$ & REP & & \\
\hline
\end{tabular}




\begin{tabular}{|l|l|l|l|l|l|l|}
16 & A & A chuva ácida. (...) & $\square$ & $\mathrm{R}$ & $\mathrm{RI}$ & \\
\hline 17 & $\mathrm{P}$ & Animais. & $\begin{array}{r}\square \\
\text { repete a fala } \\
\text { de um aluno }\end{array}$ & REP & & \\
\hline
\end{tabular}

Tabela 6: Distribuição das interações Verbais e Cognitivas em E2A1PA

\begin{tabular}{|c|c|c|c|c|c|}
\hline \multirow{2}{*}{ Interações Verbais } & \multicolumn{4}{c|}{ Interações cognitivas } \\
\cline { 2 - 6 } & \multicolumn{2}{|c|}{ Ordem Baixa } & \multicolumn{2}{c|}{ Ordem Alta } \\
\hline Categoria & $\mathbf{N}^{\circ}$ de ocorrências & CAT. & $\mathbf{N}^{\circ}$ DE OC. & CAT. & $\mathbf{N}^{\circ}$ DE OC. \\
\hline R & 7 & RI & 7 & QA & 2 \\
\hline REP & 7 & QR & 1 & SIN & 1 \\
\hline Q & 4 & QC & 1 & & \\
\hline AF & 1 & & & & Total \\
\hline Total & 19 & Total & $\mathbf{9}$ & $\mathbf{3}$ \\
\hline Distribuição das 17 falas: A=9, $\mathrm{P}=8$
\end{tabular}

Novamente os estudantes têm uma boa participação na aula contribuindo com 9 das 17 falas desse episódio. O uso de questões abertas e de repetições parece apresentar uma correlação positiva com a participação dos estudantes. Entretanto, as questões partem sempre da professora para os alunos.

Mesmo a professora usando questões que possibilitavam muitas respostas, os alunos deram respostas meramente informativas, sendo algumas delas inadequadas para as questões feitas. Isso mostra novamente um baixo envolvimento cognitivo dos estudantes. Essa afirmação pode ser justificada também pela quantidade de interações de baixa ordem que outra vez foi superior às interações de alta ordem. Todas essas interações de alta ordem foram geradas pela professora, enquanto as falas dos alunos forma marcadas apenas por respostas informativas.

Não houve dessa vez o estabelecimento de relações entre os conhecimentos científicos e o cotidiano dos estudantes, quer seja esse cotidiano direto (no ambiente próximo a ele e sua comunidade) ou indireto (no âmbito social, de sua região ou do país).

\section{Episódio 3 da aula 1 da professora A (E3A1PA)}

\begin{tabular}{|l|c|c|c|c|c|c|}
\hline \multicolumn{9}{|c|}{ E3A1PA: A formação da Chuva Ácida } \\
\hline \multirow{2}{*}{ Turno } & $\begin{array}{c}\text { Quem } \\
\text { fala? }\end{array}$ & Descrição detalhada das falas & $\begin{array}{c}\text { Observações } \\
\text { contexto }\end{array}$ & $\begin{array}{c}\text { Interação } \\
\text { verbal }\end{array}$ & \multicolumn{2}{|c|}{$\begin{array}{c}\text { Interação } \\
\text { cognitiva }\end{array}$} \\
\cline { 5 - 8 } & & O.B. & O.A. \\
\hline 1 & P & Aqui. Sabemos que a poluição & AF & INF & QA \\
\hline
\end{tabular}




\begin{tabular}{|c|c|c|c|c|c|c|c|}
\hline & & $\begin{array}{l}\text { atmosférica causa a chuva ácida. A } \\
\text { chuva ácida foi tema do bimestre } \\
\text { passado. Como acontece a chuva } \\
\text { ácida? E aí? }\end{array}$ & & & $\begin{array}{l}\mathrm{Q} \\
\mathrm{C}\end{array}$ & & \\
\hline 2 & A & $\begin{array}{l}\text { As chaminés das fábricas soltam } \\
\text { fumaça. Aí você tem enxofre... } \\
\text { substâncias de enxofre, carbono... } \\
\text { dióxido de enxofre. São as mesmas } \\
\text { que saem pelo carro (...) forma a } \\
\text { chuva ácida (...). }\end{array}$ & $\square$ & & $\mathrm{R}$ & & $\mathrm{RE}$ \\
\hline 3 & $\mathrm{~A}^{\prime}$ & Abaixa o pH. & $\square$ & & $\mathrm{R}$ & RI & \\
\hline 4 & $A^{\prime \prime}$ & $(\ldots)$ & $\square$ & & & & \\
\hline 5 & $P$ & $\begin{array}{l}\text { Ta faltando explicar o que acontece } \\
\text { quando esses gases entram em } \\
\text { contato com a água da chuva. }\end{array}$ & $\square$ & & AF & INF & \\
\hline 6 & A & $(\ldots)$ & & $\begin{array}{l}\text { inaudível } \\
\text { pois muitos } \\
\text { respondem } \\
\text { ao mesmo } \\
\text { tempo }\end{array}$ & & & \\
\hline 7 & $P$ & $\begin{array}{l}\text { Bom, a formação da chuva ácida o } \\
\text { gás primeiro junta com a água e } \\
\text { forma o que? }\end{array}$ & $\square$ & & $\begin{array}{c}\mathrm{AF} \\
\mathrm{Q}\end{array}$ & $\begin{array}{l}\text { INF } \\
\text { QF }\end{array}$ & \\
\hline 8 & A & A chuva ácida. & $\square$ & & $\mathrm{R}$ & $\mathrm{RI}$ & \\
\hline 9 & $P$ & E formam o que? Ácidos, sim? & & $\begin{array}{l}\text { pergunta } \\
\text { retórica }\end{array}$ & $\begin{array}{l}\mathrm{Q} \\
\mathrm{Q}\end{array}$ & $\begin{array}{l}\text { QR } \\
\mathrm{QC}\end{array}$ & \\
\hline 10 & A & $\begin{array}{l}\text { Ah! Formam os ácidos pra depois } \\
\text { cair a chuva ácida, né? }\end{array}$ & $\square$ & & $\begin{array}{c}\mathrm{AF} \\
\mathrm{Q}\end{array}$ & QC & SIN \\
\hline 11 & $P$ & $\begin{array}{l}\text { E esses ácidos são ácidos fortes ou } \\
\text { ácidos fracos? }\end{array}$ & $\square$ & & Q & QF & \\
\hline 12 & A & Fortes, fortes. & ם & & $\mathrm{R}$ & $\mathrm{RI}$ & \\
\hline 13 & $P$ & Sim. Alguma dúvida aqui? & $\square$ & & $\begin{array}{c}\mathrm{FB} \\
\mathrm{Q}\end{array}$ & $\begin{array}{l}\mathrm{CON} \\
\mathrm{QC}\end{array}$ & \\
\hline 14 & $A$ & Não & ם & & $\mathrm{R}$ & $\mathrm{RI}$ & \\
\hline
\end{tabular}


Tabela 7: Distribuição das interações Verbais e Cognitivas em E3A1PA

\begin{tabular}{|c|c|c|c|c|c|}
\hline \multirow{2}{*}{\multicolumn{2}{|c|}{ Interações Verbais }} & \multicolumn{4}{|c|}{ Interações Cognitivas } \\
\hline & & \multicolumn{2}{|c|}{ Ordem Baixa } & \multicolumn{2}{|c|}{ Ordem Alta } \\
\hline Categoria & $\mathrm{N}^{\circ}$ de ocorrências & CAT. & $\mathrm{N}^{\circ}$ DE OC. & CAT. & $\mathrm{N}^{\circ} \mathrm{DE}$ OC \\
\hline $\mathrm{Q}$ & 7 & $\mathrm{RI}$ & 4 & $\mathrm{QA}$ & 1 \\
\hline $\mathrm{R}$ & 5 & $\mathrm{QC}$ & 3 & $\mathrm{RE}$ & 1 \\
\hline $\mathrm{AF}$ & 4 & INF & 3 & SIN & 1 \\
\hline FB & 1 & QR & 1 & & \\
\hline \multirow[t]{2}{*}{$\mathrm{C}$} & 1 & QF & 2 & & \\
\hline & & COM & 1 & & \\
\hline Total & 18 & total & 14 & total & 3 \\
\hline
\end{tabular}

Esse curto episódio mostra a importância das questões abertas no envolvimento dos estudantes na aula. Embora as 7 questões feitas nesse episódio novamente tenham partido da professora, ela iniciou a discussão com uma questão aberta na fala 1 ("Como acontece a chuva ácida?") e, como resultado, obteve uma resposta explicativa de um aluno na fala 2 e que serviu de ponto de partida para a construção do diálogo com a sala. Como o assunto já havia sido estudado antes, a resposta do aluno foi considera correta, mas incompleta. Nas falas 5, 7 e 11 a professora A buscou ampliar a resposta dada na fala 2 fazendo questões e pedindo aos alunos que complementassem a resposta com mais detalhes sobre o processo de formação da chuva ácida e a característica do ácido formado.

Outro fato que pode ser observado não apenas nesse episódio, mas também nos dois episódios anteriores é que o uso de questões abertas em geral leva a um maior número de respostas por parte dos estudantes. Questões do tipo "O que você sabe sobre isso?" ou "Como acontece aquilo?", ou seja, questões que deixam claro que o professor está interessado principalmente no que os alunos conhecem sobre o assunto e não na resposta correta apenas, parecem deixá-los mais dispostos a participar da aula. Enquanto as questões abertas conseguem duas ou até três respostas cada uma, as questões fechadas, que em geral buscam como resposta uma informação memorizada e não a opinião sobre algum assunto ou explicação ou descrição de algum fenômeno, dificilmente obtém mais de uma resposta,

Apesar da pequena ocorrência de interações cognitivas de alta ordem em relação às interações de baixa ordem o nível cognitivo do episódio pode ser considerado bom, pois houve o aprofundamento de uma idéia (explicação do processo de formação da chuva ácida) de forma interativa e progressiva. A 
qualidade da interação poderia ter sido melhor caso houvesse um maior número de interações cognitivas de ordem alta.

\section{Episódio 4 da aula 1 da professora A (E4A1PA)}

\begin{tabular}{|c|c|c|c|c|c|c|}
\hline \multicolumn{7}{|c|}{ E4A1PA: A relação do dióxido de carbono com a acidez natural da chuva } \\
\hline \multirow[t]{2}{*}{ Turno } & \multirow{2}{*}{$\begin{array}{l}\text { Quem } \\
\text { fala? }\end{array}$} & \multirow[t]{2}{*}{ Descrição detalhada das falas } & \multirow{2}{*}{$\begin{array}{l}\text { Observações } \\
\text { contexto }\end{array}$} & \multirow{2}{*}{$\begin{array}{c}\text { Interação } \\
\text { verbal }\end{array}$} & \multicolumn{2}{|c|}{$\begin{array}{l}\text { Interação } \\
\text { cognitiva }\end{array}$} \\
\hline & & & & & O.B. & O.A. \\
\hline 1 & $\mathrm{P}$ & $\begin{array}{l}\text { Agora a gente vai estar fazendo } \\
\text { uma pequena leitura do texto } \\
\text { "Óxidos e a poluição atmosférica". } \\
\text { Vocês já receberam o texto; todos } \\
\text { já têm. }\end{array}$ & $\begin{array}{l}\text { a } \\
\text { professora } \\
\text { dá tempo } \\
\text { para que } \\
\text { todos os } \\
\text { alunos se } \\
\text { preparem }\end{array}$ & $\mathrm{O}$ & & \\
\hline 2 & $\mathrm{P}$ & $\begin{array}{l}\text { Pronto? Então acompanhem a } \\
\text { leitura. }\end{array}$ & 口 & $\mathrm{O}$ & & \\
\hline 3 & $\mathrm{P}$ & $\begin{array}{l}\text { "Podemos chamar de poluentes } \\
\text { atmosféricos toda substância } \\
\text { nociva presente no ar em } \\
\text { concentração suficiente para } \\
\text { ameaçar a saúde do ser humano, } \\
\text { contaminar animais e vegetais ou } \\
\text { ainda causar danos materiais. } \\
\text { Dentro do estudo de poluição tem } \\
\text { um grupo de materiais que ocupa } \\
\text { papel de destaque, são os óxidos". }\end{array}$ & ב & $\mathrm{L}$ & INF & \\
\hline 4 & $\mathrm{P}$ & Nós vamos estar estudando agora. & $\square$ & $\mathrm{O}$ & & \\
\hline 5 & $P$ & $\begin{array}{l}\text { "Plantas e animais, ao respirarem, } \\
\text { eliminam gás carbônico na } \\
\text { atmosfera. Podemos dizer que a } \\
\text { presença deste gás na atmosfera é } \\
\text { natural. Quando chove ocorre uma } \\
\text { reação entre ele e a água da chuva } \\
\text { produzindo o gás carbônico, que } \\
\text { deixa a água da chuva } \\
\text { ligeiramente ácida já que se trata } \\
\text { de um ácido fraco". }\end{array}$ & $\begin{array}{l}\text { parece ter } \\
\text { havido um } \\
\text { erro de } \\
\text { leitura, pois } \\
\text { deveria ser } \\
\text { "produzindo } \\
\text { o ácido } \\
\text { carbônico" } \\
\text { em lugar de } \\
\text { "produzindo } \\
\text { o gás }\end{array}$ & L & INF & \\
\hline
\end{tabular}




\begin{tabular}{|c|c|c|c|c|c|c|c|}
\hline & & & & carbônico" & & & \\
\hline 6 & $P$ & $\begin{array}{l}\text { Vocês têm aí a equação, tá? } \\
\text { Então, gás carbônico se junta com } \\
\text { a água e forma o ácido carbônico. } \\
\text { Assim como você tinha no texto da } \\
\text { chuva ácida a equação do ácido } \\
\text { sulfúrico e do ácido nítrico, então, } \\
\text { esses dois ácidos aí que formam a } \\
\text { chuva ácida. Só que será que é a } \\
\text { mesma coisa. O ácido carbônico e } \\
\text { o ácido sulfúrico têm o mesmo } \\
\text { efeito na natureza? }\end{array}$ & $\square$ & & $\begin{array}{c}\mathrm{O} \\
\mathrm{AF} \\
\mathrm{Q}\end{array}$ & $\begin{array}{l}\text { INF } \\
\text { QF }\end{array}$ & \\
\hline 7 & $A$ & Não, não. & $\square$ & & $\mathrm{R}$ & RI & \\
\hline 8 & $P$ & Não, por que? & 口 & & $\mathrm{Q}$ & & QD \\
\hline 9 & A & $(\ldots)$ & 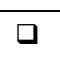 & & & & \\
\hline 10 & $P$ & $\begin{array}{l}\text { Será então que esse ácido } \\
\text { carbônico deve ser um ácido forte } \\
\text { ou fraco? }\end{array}$ & $\square$ & & $\mathrm{Q}$ & QF & \\
\hline 11 & $A$ & Fraco. & 口 & & $\mathrm{R}$ & RI & \\
\hline 12 & $P$ & Fraco. & $\square$ & $\begin{array}{l}\text { repete a } \\
\text { fala de um } \\
\text { aluno }\end{array}$ & REP & & \\
\hline 13 & $P$ & $\begin{array}{l}\text { Então, aí, ó... "Essa acidez natural } \\
\text { da chuva é tão baixa que não faz } \\
\text { mal aos seres vivos". }\end{array}$ & $\square$ & & L & INF & \\
\hline 14 & $P$ & $\begin{array}{l}\text { Aí vocês perceberam no começo } \\
\text { que falou o seguinte, a poluição } \\
\text { depende do que para ser } \\
\text { considerada poluição? Da } \\
\text { concentração. Então, que nem o } \\
\text { gás carbônico, já tá no nosso ar. } \\
\text { Nós inspiramos o que? }\end{array}$ & $\begin{array}{l} \\
\square \\
0\end{array}$ & $\begin{array}{l}\text { pergunta } \\
\text { retórica } \\
\text { enfatiza o } \\
\text { termo } \\
\text { "concentraç } \\
\text { ão" }\end{array}$ & $\begin{array}{l}\mathrm{Q} \\
\mathrm{AF} \\
\mathrm{Q}\end{array}$ & $\begin{array}{l}\text { QR } \\
\text { INF } \\
\text { QF }\end{array}$ & \\
\hline 15 & A & Oxigênio. & प & & $\mathrm{R}$ & RI & \\
\hline 16 & $P$ & E nós expiramos... & 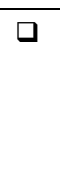 & $\begin{array}{l}\text { solicita que } \\
\text { completem } \\
\text { a frase }\end{array}$ & $\mathrm{Q}$ & $\mathrm{CP}$ & \\
\hline 17 & $A$ & Gás carbônico. & a & & $\mathrm{R}$ & RI & \\
\hline 18 & $P$ & $\begin{array}{l}\text { Então já existe gás carbônico no } \\
\text { ar. Todo ser vivo quando respira }\end{array}$ & व & & $\begin{array}{c}\mathrm{AF} \\
\mathrm{Q}\end{array}$ & $\begin{array}{l}\text { INF } \\
\mathrm{QC}\end{array}$ & \\
\hline
\end{tabular}




\begin{tabular}{|l|l|l|l|l|l|} 
& & $\begin{array}{l}\text { elimina gás carbônico no ar. Muito. } \\
\text { Tá? }\end{array}$ & & & \\
\hline 19 & $\mathrm{P}$ & $\begin{array}{l}\text { Aí, com o aumento da queima dos } \\
\text { combustíveis fósseis vai aumentar } \\
\text { a concentração e aí ele se torna } \\
\text { um poluente. }\end{array}$ & AF & INF & \\
\hline
\end{tabular}

Obs.: Na fala 16, a professora A solicita que os estudantes completem a frase "E nós expiramos..." o que foi interpretado como tendo o significado e o valor de uma questão como "E nós expiramos 0 quê?".

Percebe-se nesse episódio uma mudança na dialogicidade da aula. A professora A passa a ter maior tempo de fala em relação aos alunos. Dentre as 19 falas do episódio, apenas 5 foram produzidas pelos alunos e mesmo assim 1 delas foi inaudível e as outras 4 foram respostas informativas curtas: "Não, não" (fala 7); "Fraco" (fala 11); "Oxigênio" (fala 15) e "Gás carbônico" (fala 17).

Outro ponto interessante é a grande disparidade entre as interações cognitivas de baixa ordem (17) e ordem alta (apenas 1), como mostra a tabela 7.

A questão apresentada na fala 8 foi de grande importância dentro do diálogo por confrontar a resposta injustificada apresentada pelo estudante na fala 7 e levar a turma a refletir mais profundamente na questão final da fala 6. Essa solicitação de justificativa ("Não, por quê?") eleva a complexidade da questão inicial ("O ácido carbônico e o ácido sulfúrico têm o mesmo efeito na natureza?") e o nível cognitivo da interação. Essa estratégia - propor uma questão fechada e depois pedir uma justificativa para levar a reflexão mais aprofundada - parece ser uma forma interessante de aumentar o nível cognitivo das discussões. Primeiro, a questão fechada é geralmente mais simples e pode promover uma participação inicial do estudante sem que corra grandes riscos de fracassar em sua tentativa de resposta e, depois, o pedido de justificativa tanto valoriza a resposta dada, como se fosse dito "Ouvi sua resposta e gostaria de saber mais sobre o que você pensa", quanto convida o respondente a dar continuidade ao seu raciocínio, levando-o à reflexão mais aprofundada sobre a problemática posta. Infelizmente, nesse episódio não foi dada seqüência à questão posta na fala 8 e o problema foi dividido em questões fechadas e as interações voltaram a ter um baixo nível cognitivo.

A pouca participação dos alunos e o baixo nível cognitivo das interações com a ausência principalmente de questões abertas parecem estar intimamente relacionados nesse episódio. 
Tabela 8: Distribuição das interações Verbais e Cognitivas em E4A1PA

\begin{tabular}{|c|c|c|c|c|c|}
\hline \multicolumn{2}{|c|}{ Interações Verbais } & \multicolumn{4}{c|}{ Interações Cognitivas } \\
\cline { 2 - 6 } \multicolumn{2}{|c|}{} & \multicolumn{2}{|c|}{ Ordem Baixa } & \multicolumn{2}{c|}{ Ordem Alta } \\
\hline Categoria & $\mathbf{N}^{\circ}$ de Ocorrências & CAT. & $\mathbf{N}^{\circ}$ DE OC. & CAT. & $\mathbf{N}^{\circ}$ DE OC. \\
\hline Q & 7 & INF & 7 & QD & 1 \\
\hline O & 4 & RI & 4 & & \\
\hline AF & 4 & QF & 3 & & \\
\hline R & 4 & QR & 1 & & \\
\hline L & 3 & QC & 1 & & \\
\hline REP & 1 & CP & 1 & & 1 \\
\hline Total & $\mathbf{2 3}$ & total & $\mathbf{1 7}$ & Total & $\mathbf{1}$ \\
\hline Distribuição das 19 falas: A=5, P=14
\end{tabular}

\section{Episódio 5 da aula 1 da professora A (E5A1PA)}

\begin{tabular}{|c|c|c|c|c|c|c|}
\hline \multicolumn{7}{|c|}{ E5A1PA: Os produtos da combustão } \\
\hline \multirow[t]{2}{*}{ Turno } & \multirow{2}{*}{$\begin{array}{l}\text { Quem } \\
\text { fala? }\end{array}$} & \multirow[t]{2}{*}{ Descrição detalhada das falas } & \multirow{2}{*}{$\begin{array}{l}\text { Observações } \\
\text { Contexto }\end{array}$} & \multirow{2}{*}{$\begin{array}{l}\text { Interação } \\
\text { verbal }\end{array}$} & \multicolumn{2}{|c|}{$\begin{array}{l}\text { Interação } \\
\text { cognitiva }\end{array}$} \\
\hline & & & & & O.B. & O.A. \\
\hline 1 & $\mathrm{P}$ & $\begin{array}{l}\text { "A combustão do álcool e da } \\
\text { gasolina dentro dos motores dos } \\
\text { automóveis produz uma mistura } \\
\text { de dióxido de carbono, } \\
\text { monóxido de carbono, carvão } \\
\text { pulverizado ou fuligem e água". }\end{array}$ & $\square$ & L & INF & \\
\hline 2 & A & $\begin{array}{l}\text { A fuligem não é o nome da... ah, } \\
\text { tudo bem. }\end{array}$ & $\square$ & & & \\
\hline 3 & $\mathrm{P}$ & $\begin{array}{l}\text { Então, nós temos aí... Ah, } \\
\text { quando você queima um } \\
\text { combustível, por que elimina } \\
\text { tudo isso: gás carbônico, } \\
\text { monóxido de carbono, carvão, } \\
\text { fuligem e água? Quem sabe? }\end{array}$ & $\square$ & $\begin{array}{l}\mathrm{Q} \\
\mathrm{C}\end{array}$ & & QA \\
\hline 4 & A & Boa pergunta! & $\square$ & & & \\
\hline 5 & A & Como que é? & $\square$ & Q & QF & \\
\hline 6 & $\mathrm{P}$ & $\begin{array}{l}\text { Quando você queima, } \\
\text { normalmente você fala que só } \\
\text { tem o gás carbônico e a água e } \\
\text { aqui você tá falando que tem o } \\
\text { monóxido de carbono e a } \\
\text { fuligem. Por que? }\end{array}$ & $\square$ & $\begin{array}{l}\mathrm{AF} \\
\mathrm{Q}\end{array}$ & $\begin{array}{l}\text { INF } \\
\text { REF }\end{array}$ & \\
\hline
\end{tabular}




\begin{tabular}{|c|c|c|c|c|c|c|}
\hline 7 & $A$ & $\begin{array}{l}\text { Como que é a pergunta, } \\
\text { professora? }\end{array}$ & 口 & Q & QF & \\
\hline 8 & $P$ & $\begin{array}{l}\text { Por que na combustão você não } \\
\text { libera só o gás carbônico e } \\
\text { água, libera também monóxido } \\
\text { de carbono e fuligem? Quem } \\
\text { sabe dizer? }\end{array}$ & $\begin{array}{l}\text { ela dá } \\
\text { tempo para } \\
\text { eles } \\
\text { pensarem e } \\
\text { respondere } \\
\text { m }\end{array}$ & $\begin{array}{l}\mathrm{Q} \\
\mathrm{C}\end{array}$ & REF & \\
\hline 9 & $P$ & $\begin{array}{l}\text { Vocês lembram quando eu falei } \\
\text { da estória lá da garagem... } \\
\text { quando você esquenta o carro } \\
\text { na garagem? }\end{array}$ & $\square$ & Q & $\begin{array}{l}\text { REV } \\
\text { QF }\end{array}$ & \\
\hline 10 & A & $\begin{array}{l}\text { Ah, quando você esquenta o } \\
\text { carro. }\end{array}$ & a & $\mathrm{R}$ & RI & \\
\hline 11 & $P$ & $\begin{array}{l}\text { Isso. O que acontecia? O que } \\
\text { faltava ali? }\end{array}$ & $\square$ & $\begin{array}{c}\text { FB } \\
\mathrm{Q} \\
\mathrm{Q}\end{array}$ & $\begin{array}{l}\text { CON } \\
\text { QF }\end{array}$ & QA \\
\hline 12 & $A$ & Oxigênio. & $\square$ & $\mathrm{R}$ & RI & \\
\hline 13 & $P$ & $\begin{array}{l}\text { Quando você não tem oxigênio } \\
\text { suficiente você começa a } \\
\text { produzir monóxido de carbono e } \\
\text { fuligem. Certo? Então, } \\
\text { dependendo da quantidade de } \\
\text { oxigênio você vai produzir } \\
\text { fuligem. }\end{array}$ & ם & $\begin{array}{c}\mathrm{AF} \\
\mathrm{Q} \\
\mathrm{AF}\end{array}$ & $\begin{array}{l}\text { INF } \\
\text { QC }\end{array}$ & SIN \\
\hline
\end{tabular}

Nesse episódio há um equilíbrio relativo nas quantidades de verbalizações. Os alunos se expressam 6 vezes e a professora A 7 vezes. Entretanto as falas dos alunos promovem interações cognitivas de baixa ordem e 3 das questões abertas apresentadas pela professora foram na verdade reformulações de uma única questão que não havia sido compreendida pelos alunos. A outra questão aberta proposta pela professora foi seguida e 'suprimida' imediatamente por uma questão fechada e mais simples (fala 11). A professora cometeu dois erros naquele instante: não deu tempos aos alunos de responderem a questão "O que acontecia [quando esquenta o carro na garagem]?" e propôs mais de uma questão ao mesmo tempo, fazendo com que os alunos respondessem a mais fácil e ignorassem a outra. Por fim, a professora acaba ela mesma respondendo as duas questões importantes 
desse episódio (falas 3 e 11) e que poderiam ter levado os alunos a interações cognitivas de alta ordem.

As duas reformulações feitas pela professora (falas 6 e 8) para a questão aberta da fala 3 mostram, por um lado, o interesse de parte dos alunos em compreender uma questão aparentemente desafiadora para eles e, por outro, a necessidade de elaborar questões que sejam, ao mesmo tempo, cognitivamente desafiadoras como também compreensíveis. Embora não tenha havido qualquer problema com a questão inicialmente apresentada pela professora A, é interessante assinalarmos aqui a necessidade de se equilibrar o desafio cognitivo e a inteligibilidade na composição de uma questão.

Tabela 9: Distribuição das interações Verbais e Cognitivas em E5A1PA

\begin{tabular}{|c|c|c|c|c|c|}
\hline \multirow{2}{*}{\multicolumn{2}{|c|}{ Interações Verbais }} & \multicolumn{4}{|c|}{ Interações Cognitivas } \\
\hline & & \multicolumn{2}{|c|}{ Ordem Baixa } & \multicolumn{2}{|c|}{ Ordem Alta } \\
\hline Categoria & $\mathrm{N}^{\circ}$ de Ocorrências & CAT. & $\mathrm{N}^{\circ}$ DE OC. & CAT. & $\mathrm{N}^{\circ}$ DE OC. \\
\hline $\mathrm{Q}$ & 9 & QF & 4 & QA & 2 \\
\hline $\mathrm{AF}$ & 3 & INF & 3 & SIN & 1 \\
\hline $\mathrm{C}$ & 2 & $\mathrm{RI}$ & 2 & & \\
\hline $\mathrm{R}$ & 2 & REF & 2 & & \\
\hline $\mathrm{L}$ & 1 & $\mathrm{QC}$ & 1 & & \\
\hline \multirow[t]{2}{*}{ FB } & 1 & CON & 1 & & \\
\hline & & REV & 1 & & \\
\hline Total & 18 & Total & 14 & Total & 3 \\
\hline
\end{tabular}

\section{Episódio 6 da aula 1 da professora A (E6A1PA)}

\begin{tabular}{|c|c|c|c|c|c|c|}
\hline \multicolumn{7}{|c|}{ E6A1PA: Problemas causados pelos produtos da combustão } \\
\hline \multirow[t]{2}{*}{ Turno } & \multirow{2}{*}{$\begin{array}{l}\text { Quem } \\
\text { fala? }\end{array}$} & \multirow[t]{2}{*}{ Descrição detalhada das falas } & \multirow{2}{*}{$\begin{array}{c}\text { Observações } \\
\text { Contexto }\end{array}$} & \multirow{2}{*}{$\begin{array}{c}\text { Interação } \\
\text { verbal }\end{array}$} & \multicolumn{2}{|c|}{$\begin{array}{l}\text { Interação } \\
\text { cognitiva }\end{array}$} \\
\hline & & & & & O.B. & O.A. \\
\hline 1 & $\mathrm{P}$ & $\begin{array}{l}\text { Outra coisa: "A produção de gás } \\
\text { carbônico faz aumentar a } \\
\text { concentração desse gás na } \\
\text { atmosfera. Como conseqüência } \\
\text { desse aumento na concentração } \\
\text { de gás carbônico as pessoas têm } \\
\text { chamado de efeito estufa, que } \\
\text { tende a aumentar a temperatura } \\
\text { média do planeta". }\end{array}$ & a & $\mathrm{L}$ & INF & \\
\hline 2 & $\mathrm{P}$ & Isso a gente já sabe. Outro gás & व & AF & INF & \\
\hline
\end{tabular}




\begin{tabular}{|c|c|c|c|c|c|c|c|}
\hline & & $\begin{array}{l}\text { que se forma, o monóxido de } \\
\text { carbono, ele é extremamente } \\
\text { tóxico. Qual o problema do } \\
\text { monóxido? O que que tá grifado? }\end{array}$ & & & Q & QF & \\
\hline 3 & $A$ & Ele não tem cheiro. & $\square$ & & $\mathrm{R}$ & $\mathrm{RI}$ & \\
\hline 4 & $P$ & $\begin{array}{l}\text { Ele não tem cheiro e não tem cor. } \\
\text { A gente percebe, então, ele? }\end{array}$ & $\square$ & & $\begin{array}{l}\mathrm{AF} \\
\mathrm{Q}\end{array}$ & $\begin{array}{l}\text { INF } \\
\text { QF }\end{array}$ & \\
\hline 5 & A & Não. & a & & $\mathrm{R}$ & $\mathrm{RI}$ & \\
\hline 6 & $\mathrm{P}$ & $\begin{array}{l}\text { Se ele é tóxico, o que ele pode } \\
\text { causar? }\end{array}$ & $\square$ & & Q & & QA \\
\hline 7 & $A$ & $(\ldots)$ & $\square$ & & & & \\
\hline 8 & $\mathrm{P}$ & Sim, e o que mais? & $\square$ & & $\begin{array}{l}\text { FB } \\
\text { REP }\end{array}$ & CON & \\
\hline 9 & A & $\begin{array}{l}\text { Na respiração, né? Doença de } \\
\text { respiração. }\end{array}$ & $\square$ & & $\begin{array}{l}\mathrm{R} \\
\mathrm{Q}\end{array}$ & $\begin{array}{l}\mathrm{RI} \\
\mathrm{QC}\end{array}$ & \\
\hline 10 & $\mathrm{P}$ & $\begin{array}{l}\text { O que vai acontecer na garagem } \\
\text { fechada?(...) Dependendo da } \\
\text { quantidade a pessoa pode morrer. }\end{array}$ & a & & $\begin{array}{c}\mathrm{Q} \\
\mathrm{AF}\end{array}$ & $\begin{array}{l}\text { QR } \\
\text { INF }\end{array}$ & \\
\hline 11 & $P$ & $\begin{array}{l}\text { "Um das principais impurezas que } \\
\text { existem nos derivados de } \\
\text { petróleo", que a gente já estudou, } \\
\text { qual é? O que isso faz? impureza } \\
\text { aí... }\end{array}$ & $\square$ & & $\begin{array}{l}\mathrm{Q} \\
\mathrm{Q}\end{array}$ & QF & QA \\
\hline 12 & A & Gasolina, óleo. & $\square$ & & $\mathrm{R}$ & RI & \\
\hline 13 & $\mathrm{P}$ & $\begin{array}{l}\text { Não, não, não. A impureza } \\
\text { presente nos combustíveis como } \\
\text { gasolina, petróleo... que nós } \\
\text { fizemos no laboratório. }\end{array}$ & $\square$ & & $\begin{array}{l}\mathrm{FB} \\
\mathrm{AF}\end{array}$ & $\begin{array}{l}\text { DIS } \\
\text { INF }\end{array}$ & \\
\hline 14 & A & Enxofre, enxofre. & प & & $\mathrm{R}$ & $\mathrm{RI}$ & \\
\hline 15 & $\mathrm{P}$ & $\begin{array}{l}\text { O enxofre causa problema na } \\
\text { natureza ou no ar? O enxofre. }\end{array}$ & a & & $\mathrm{Q}$ & QF & \\
\hline 16 & A & Não! & प & & $\mathrm{R}$ & RI & \\
\hline 17 & $\mathrm{P}$ & Quando que ele vai causar? & $\square$ & & $\mathrm{Q}$ & QF & \\
\hline 18 & A & Quando vira dióxido. & $\square$ & & $\mathrm{R}$ & $\mathrm{RI}$ & \\
\hline 19 & $P$ & $\begin{array}{l}\text { Quando que vira dióxido de } \\
\text { carbono. }\end{array}$ & & $\begin{array}{l}\text { houve um } \\
\text { erro aqui, } \\
\text { pois onde se } \\
\text { disse } \\
\text { "dióxido de } \\
\text { carbono" }\end{array}$ & Q & QF & \\
\hline
\end{tabular}




\begin{tabular}{|c|c|c|c|c|c|c|}
\hline & & & $\begin{array}{l}\text { deveria ser } \\
\text { dito "dióxido } \\
\text { de enxofre" }\end{array}$ & & & \\
\hline 20 & A & Quando queima. & a & $\mathrm{R}$ & RI & \\
\hline 21 & $\mathrm{P}$ & Quando ele é queimado. & $\begin{array}{l}\text { repete a fala } \\
\text { de um aluno }\end{array}$ & REP & & \\
\hline 22 & A & $\begin{array}{l}\text { Ele normal não vai fazer nada, } \\
\text { né? }\end{array}$ & 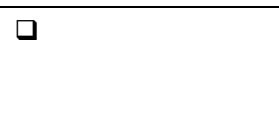 & $\begin{array}{l}\mathrm{AF} \\
\mathrm{Q}\end{array}$ & $\begin{array}{l}\text { INF } \\
\mathrm{QC}\end{array}$ & \\
\hline 23 & $A^{\prime}$ & $\begin{array}{l}\text { Não, ele não faz nada quando é } \\
\text { normal. }\end{array}$ & $\square$ & $\mathrm{R}$ & $\mathrm{RI}$ & \\
\hline 24 & $P$ & $\begin{array}{l}\text { O que acontece? A gente testou } \\
\text { na água, no papelzinho... } \\
\text { Lembra? }\end{array}$ & $\square$ & $\begin{array}{l}\mathrm{Q} \\
\mathrm{AF} \\
\mathrm{Q}\end{array}$ & $\begin{array}{l}\text { REV } \\
\text { QC }\end{array}$ & QA \\
\hline 25 & A & Na pétala. & $\square$ & AF & INF & \\
\hline 26 & $\mathrm{P}$ & Na pétala & $\begin{array}{l}\text { repete a fala } \\
\text { o aluno }\end{array}$ & REP & & \\
\hline 27 & A & No tornassol azul. & $\square$ & AF & INF & \\
\hline 28 & $P$ & E na pétala dentro do frasquinho? & a & Q & & $\mathrm{QA}$ \\
\hline 29 & A & Queimou. & ב & $\mathrm{R}$ & $\mathrm{RD}$ & \\
\hline 30 & $\mathrm{P}$ & $\begin{array}{l}\text { Então o efeito do enxofre não é o } \\
\text { mesmo do dióxido de enxofre. } \\
\text { Sim? Então, uma das principais } \\
\text { impurezas aí é o enxofre e } \\
\text { quando ocorre a queima produz o } \\
\text { dióxido de enxofre, "que é um } \\
\text { óxido ácido de cheiro bastante } \\
\text { irritante. Na atmosfera o dióxido } \\
\text { de enxofre reage lentamente com } \\
\text { o oxigênio e se transforma em } \\
\text { trióxido de enxofre". Aí explica, } \\
\text { né? É uma reação difícil, mas } \\
\text { com a poeira do ar atmosférico, a } \\
\text { gente já tinha visto isso no texto } \\
\text { da chuva ácida, ele se transforma } \\
\text { no ácido sulfúrico, que é um ácido } \\
\text { forte. E aí tem o tema da chuva } \\
\text { ácida que é responsável por } \\
\text { vários problemas, como a gente já } \\
\text { viu e eu coloquei aí pra retomar. } \\
\text { Como a gente tá vendo poluição }\end{array}$ & $\begin{array}{l}\text { convida os } \\
\text { alunos a } \\
\text { completarem } \\
\text { a frase }\end{array}$ & $\begin{array}{c}\mathrm{AF} \\
\mathrm{Q} \\
\mathrm{AF} \\
\mathrm{L} \\
\mathrm{Q} \\
\mathrm{AF} \\
\mathrm{L} \\
\mathrm{AF} \\
\mathrm{Q}\end{array}$ & $\begin{array}{c}\text { QC } \\
\text { INF } \\
\text { INF } \\
\text { QC } \\
\text { INF } \\
\text { INF } \\
\text { INF } \\
\text { CP }\end{array}$ & SIN \\
\hline
\end{tabular}




\begin{tabular}{|c|c|c|c|c|c|c|}
\hline & & $\begin{array}{l}\text { atmosférica a gente vai retomar a } \\
\text { matéria do bimestre passado, } \\
\text { falando de chuva ácida. "Quais } \\
\text { são as conseqüências da chuva } \\
\text { ácida? Prejuízos para a } \\
\text { agricultura, pois o solo se torna } \\
\text { ácido e ao mesmo tempo o } \\
\text { dióxido de enxofre, aquele gás } \\
\text { produzido na queima do enxofre, } \\
\text { destrói as folhas dos vegetais". } \\
\text { Outra conseqüência: a água dos } \\
\text { rios e lagos se torna ácida e } \\
\text { conseqüentemente... }\end{array}$ & & & & \\
\hline 31 & A & $\begin{array}{l}\text { Imprópria para a vida dos peixes, } \\
\text { né? }\end{array}$ & a & $\begin{array}{c}\mathrm{AF} \\
\mathrm{Q}\end{array}$ & $\begin{array}{l}\text { INF } \\
\mathrm{QC}\end{array}$ & \\
\hline 32 & $P$ & Por quê? & a & $\mathrm{Q}$ & & QD \\
\hline 33 & A & Porque os peixes morrem. & a Risos & $\mathrm{R}$ & $\mathrm{RI}$ & \\
\hline 34 & $\mathrm{P}$ & $\begin{array}{l}\text { E a corrosão do mármore? O que } \\
\text { que acontece com o mármore? }\end{array}$ & $\square$ & $\mathrm{Q}$ & QF & \\
\hline 35 & A & $\begin{array}{l}\text { Pô, a corrosão corrói? Eu não } \\
\text { sabia não! }\end{array}$ & $\square$ & $\begin{array}{c}\mathrm{R} \\
\mathrm{AF}\end{array}$ & $\begin{array}{c}\mathrm{RI} \\
\mathrm{INF}\end{array}$ & \\
\hline 36 & $P$ & $\begin{array}{l}\text { A chuva ácida faz o que com o } \\
\text { mármore? Quem lembra? }\end{array}$ & 口 & $\begin{array}{l}\mathrm{Q} \\
\mathrm{C}\end{array}$ & REF & \\
\hline 37 & A & Corrói, corrói. Ele vira gesso. & $\square$ & $\mathrm{R}$ & $\mathrm{RI}$ & \\
\hline 38 & $\mathrm{P}$ & Se transforma em gesso. & $\begin{array}{l}\text { repete a fala } \\
\text { de um aluno }\end{array}$ & REP & & \\
\hline 39 & A & Viu? Eu não disse? & 口 & & & \\
\hline 40 & $A^{\prime}$ & O que que eu disse? & $\square$ & & & \\
\hline 41 & $\mathrm{P}$ & $\begin{array}{l}\text { "No motor dos automóveis ocorre } \\
\text { a entrada de ar, cujo oxigênio é } \\
\text { necessário para a combustão". }\end{array}$ & $\square$ & L & INF & \\
\hline 42 & $P$ & $\begin{array}{l}\text { Então, junto com o oxigênio... } \\
\text { será que entra só oxigênio no } \\
\text { motor? }\end{array}$ & a & Q & QF & \\
\hline 43 & A & Não. & $\square$ & $\mathrm{R}$ & $\mathrm{RI}$ & \\
\hline 44 & $P$ & $\begin{array}{l}\text { Não, entra também outros gases, } \\
\text { inclusive o nitrogênio. E aí, o que } \\
\text { que acontece com o nitrogênio } \\
\text { dentro dos motores? }\end{array}$ & $\square$ & $\begin{array}{c}\text { REP } \\
\text { AF } \\
Q\end{array}$ & INF & QA \\
\hline 45 & A & Faz a queima e aí funciona o & $\square$ & $\mathrm{R}$ & & $\mathrm{RE}$ \\
\hline
\end{tabular}




\begin{tabular}{|c|c|c|c|c|c|}
\hline & & motor. & & & \\
\hline 46 & $P$ & Aí forma o quê? & a & Q & QF \\
\hline 47 & A & Uma reação (...) & a & $\mathrm{R}$ & $\mathrm{RI}$ \\
\hline 48 & $P$ & $\begin{array}{l}\text { Aí ele vai reagir formando que } \\
\text { gases? }\end{array}$ & $\square$ & $\mathrm{Q}$ & REF \\
\hline 49 & A & $(\ldots)$ & a & & \\
\hline 50 & $P$ & $\begin{array}{l}\text { Entrou nitrogênio... óxidos de } \\
\text { nitrogênio. Sim? O que que os } \\
\text { óxido de nitrogênio causam algum } \\
\text { problema pra atmosfera? }\end{array}$ & a & $\begin{array}{c}\mathrm{AF} \\
\mathrm{Q} \\
\mathrm{Q}\end{array}$ & $\begin{array}{l}\text { INF } \\
\text { QC } \\
\text { QF }\end{array}$ \\
\hline 51 & $A$ & Sim, é óbvio que sim. & a & $\mathrm{R}$ & $\mathrm{RI}$ \\
\hline 52 & $\mathrm{P}$ & Vocês já viram, né? & ב & $\begin{array}{c}\mathrm{AF} \\
\mathrm{Q}\end{array}$ & $\begin{array}{l}\text { INF } \\
\mathrm{QC}\end{array}$ \\
\hline 53 & $A$ & É verdade & a & $\mathrm{R}$ & $\mathrm{RI}$ \\
\hline
\end{tabular}

Obs.: No final da fala 30 a professora solicita que os alunos completem uma frase, o que foi considerado como equivalendo a fazer uma questão. O mesmo ocorreu na fala 16 de E4PA.

Tabela 10: Distribuição das Interações Verbais e Cognitivas em E6A1PA

\begin{tabular}{|c|c|c|c|c|c|}
\hline \multirow{2}{*}{ Interações Verbais } & \multicolumn{4}{c|}{ Interações Cognitivas } \\
\cline { 2 - 6 } & & \multicolumn{2}{c|}{ Ordem Baixa } & \multicolumn{2}{c|}{ Ordem Alta } \\
\hline Categoria & $\mathbf{N}^{\circ}$ de Ocorrências & CAT. & $\mathbf{N}^{\circ}$ DE OC. & CAT. & $\mathbf{N}^{\circ}$ DE OC. \\
\hline Q & 28 & INF & 19 & QA & 5 \\
\hline R & 18 & RI & 17 & RE & 1 \\
\hline AF & 17 & QF & 10 & QD & 1 \\
\hline L & 4 & QC & 8 & SIN & 1 \\
\hline REP & 5 & REF & 2 & & \\
\hline FB & 2 & QR & 1 & & \\
\hline C & 1 & DIS & 1 & & \\
\hline & & RD & 1 & & \\
\hline & CP & 1 & & \\
\hline & & CON & 1 & & \\
\hline & & REV & 1 & & \\
\hline Distribuição das 53 falas: A= 26, P=27 & total & $\mathbf{6 2}$ & total & $\mathbf{8}$ \\
\hline
\end{tabular}

Nesse episódio houve um equilíbrio entre a quantidade de falas da professora (27) e dos alunos (26). Embora as falas da professora tenham continuado muito mais longas do que as falas dos estudantes, como ocorreu em toda a aula, o grande número de verbalizações dos alunos mostra que essa parte da aula foi bastante interativa. Essa interatividade pode ser atribuída ao grande número de questões propostas nesse episódio. Em 53 falas foram feitas 28 questões, sendo 10 fechadas, 8 de confirmação - que raramente são respondidas - e 5 abertas. 
Contudo essa interatividade não se refletiu num maior nível de interações cognitivas de alta ordem. A tabela 10 mostra que houve muito mais interações cognitivas de baixa ordem (62) do que de alta ordem (apenas 8).

A contextualização dos conhecimentos químicos nesse episódio e nos dois anteriores ficou a cargo principalmente das informações advindas do texto. As relações entre o conhecimento científico e o cotidiano ou as relações CTSA foram exploradas apenas no nível necessário para a compreensão das questões apresentadas na leitura do texto. Não foram apresentadas questões externas ao conteúdo abordado no texto nem pela professora nem pelos alunos.

\section{Episódio 7 da aula 1 da professora A (E7A1PA)}

\begin{tabular}{|c|c|c|c|c|c|c|}
\hline \multicolumn{7}{|c|}{ E7A1PA: A ocorrência natural do dióxido de nitrogênio } \\
\hline \multirow[t]{2}{*}{ Turno } & \multirow{2}{*}{$\begin{array}{l}\text { Quem } \\
\text { fala? }\end{array}$} & \multirow[t]{2}{*}{ Descrição detalhada das falas } & \multirow{2}{*}{$\begin{array}{l}\text { Observações } \\
\text { Contexto }\end{array}$} & \multirow{2}{*}{$\begin{array}{c}\text { Interação } \\
\text { verbal }\end{array}$} & \multicolumn{2}{|c|}{$\begin{array}{l}\text { Interação } \\
\text { cognitiva }\end{array}$} \\
\hline & & & & & O.B. & O.A. \\
\hline 1 & $\mathrm{P}$ & $\begin{array}{l}\text { Bom... ahhh... "O ácido nítrico é } \\
\text { um ácido forte juntamente com o } \\
\text { ácido sulfúrico é responsável pela } \\
\text { chuva ácida". A gente já viu isso. } \\
\text { Outra coisa que vocês têm aí no } \\
\text { texto e que não tinha no texto da } \\
\text { chuva ácida. "Curiosamente o } \\
\text { óxido nítrico não surge na chuva } \\
\text { devido apenas à poluição. Nos } \\
\text { raios que se formam durante as } \\
\text { tempestades também se forma } \\
\text { monóxido de nitrogênio e dióxido } \\
\text { de nitrogênio, que conduzem ao } \\
\text { aparecimento deste ácido na } \\
\text { chuva". Isso também quer dizer o } \\
\text { quê? }\end{array}$ & $\square$ & $\begin{array}{c}\mathrm{L} \\
\mathrm{AF} \\
\mathrm{L} \\
\mathrm{Q}\end{array}$ & $\begin{array}{l}\text { INF } \\
\text { INF } \\
\text { INF }\end{array}$ & QA \\
\hline 2 & A & $\begin{array}{l}\text { Que os raios também tem os } \\
\text { gases lá. }\end{array}$ & $\square$ & $\mathrm{R}$ & $\mathrm{RI}$ & \\
\hline 3 & $\mathrm{P}$ & Tem os gases? & $\begin{array}{l}\text { repete para } \\
\text { causar } \\
\text { dúvida ou } \\
\text { reflexão }\end{array}$ & Q & & QD \\
\hline
\end{tabular}




\begin{tabular}{|c|c|c|c|c|c|c|c|}
\hline 4 & A & Eles formam. & ם & & $\mathrm{R}$ & & $\mathrm{RE}$ \\
\hline 5 & $\mathrm{P}$ & Eles formam! & & $\begin{array}{l}\text { repete para } \\
\text { confirmar } \\
\text { uma } \\
\text { resposta } \\
\text { corretas }\end{array}$ & REP & & \\
\hline 6 & $A^{\prime}$ & É, pode crer. & a & & FB & CON & \\
\hline 7 & $\mathrm{P}$ & $\begin{array}{l}\text { O dióxido de nitrogênio. Sim? } \\
\text { Quer dizer que numa região onde } \\
\text { não tem poluição pode ter a } \\
\text { presença desse ácido nítrico aí? }\end{array}$ & a & & $\begin{array}{c}\mathrm{AF} \\
\mathrm{Q} \\
\mathrm{Q}\end{array}$ & $\begin{array}{l}\text { INF } \\
\text { QC } \\
\text { QF }\end{array}$ & \\
\hline 8 & A & Pode! & a & & $\mathrm{R}$ & $\mathrm{RI}$ & \\
\hline 9 & $P$ & Desde que... & & $\begin{array}{l}\text { completem } \\
\text { a frase }\end{array}$ & Q & $\mathrm{CP}$ & \\
\hline 10 & A & Tenha raios. & a & & $\mathrm{R}$ & $\mathrm{RI}$ & \\
\hline 11 & $P$ & $\begin{array}{l}\text { Que a chuva seja acompanhada } \\
\text { de raio. OK? Aí vocês têm aí a } \\
\text { equação, que tem outra } \\
\text { informação aí. }\end{array}$ & a & & $\begin{array}{c}\text { PAR } \\
\mathrm{Q} \\
\mathrm{AF}\end{array}$ & $\begin{array}{l}\mathrm{RI} \\
\mathrm{QC} \\
\text { INF }\end{array}$ & \\
\hline
\end{tabular}

Obs.: Na fala 9 a professora A convida os alunos a completarem sua frase. Essa solicitação foi interpretada como equivalendo a uma questão.

A professora A, após a leitura de alguns extratos do texto, faz uma questão aberta aos alunos: Isso também quer dizer o quê? (turno 1). O uso de questões abertas, embora favoreça o estabelecimento de interações cognitivas de alta ordem, deve ser feito com cautela. Algumas vezes a questão é "tão aberta" que o questionado não sabe que tipo de informação o interlocutor quer como resposta. Foi o que ocorreu com essa questão. Como resultado dessa questão mal elaborada os alunos emitiram respostas insatisfatórias e a professora foi obrigada a mudar sua estratégia e propor uma questão fechada em substituição a essa questão aberta: Quer dizer que numa região onde não tem poluição pode ter a presença desse ácido nítrico aí? (turno 7). Trata-se, neste caso, não de uma elaboração de raciocínio em que o diálogo teria sido conduzido de forma a levar os alunos a concluírem que a chuva ácida pode ocorrer mesmo em locais não poluídos, mas sim uma mudança de estratégia já que a resposta desejada não pôde ser obtida na primeira questão. Além disso, a proposição dessa nova questão, agora uma questão fechada, apresenta um valor formativo inferior pelo fato de não incentivar os alunos a estabelecer a relação entre a forma pela qual os óxidos são produzidos e o local onde isso pode ocorrer. 
Sendo assim, os alunos passaram a ter uma posição mais passiva de receptores da nova informação.

A tabela 10, a seguir, mostra a freqüência com que ocorre cada uma das categorias nas duas dimensões, verbal e cognitiva. Nota-se, novamente, uma maior quantidade de interações cognitiva de baixa ordem em relação às interações cognitiva de alta ordem; a prevalência de questões e respostas de baixa ordem cognitiva e poucos feedbacks para as respostas dadas.

Tabela 11: Distribuição das interações Verbais e Cognitivas em E7A1PA

\begin{tabular}{|c|c|c|c|c|c|}
\hline \multirow{2}{*}{ Interações verbais } & \multicolumn{4}{c|}{ Interações Cognitivas } \\
\cline { 2 - 6 } & & \multicolumn{2}{|c|}{ Ordem Baixa } & \multicolumn{2}{c|}{ Ordem Alta } \\
\hline Categorias & $\mathbf{N}^{\mathbf{0}}$ de ocorrências & CAT. & $\mathbf{N}^{\circ}$ DE OC. & CAT. & $\mathbf{N}^{\circ}$ DE OC. \\
\hline Q & 6 & INF & 5 & RE & 1 \\
\hline R & 4 & RI & 4 & QD & 1 \\
\hline AF & 3 & QC & 2 & QA & 1 \\
\hline L & 2 & CP & 1 & & \\
\hline REP & 1 & CON & 1 & & \\
\hline PAR & 1 & QF & 1 & & \\
\hline FB & 1 & & & & total \\
\hline Total & $\mathbf{1 8}$ & Total & $\mathbf{1 4}$ & \\
\hline Distribuição das 11 falas: A=5, P=6
\end{tabular}

\section{Episódio 8 da aula 1 da professora A (E8A1PA)}

\begin{tabular}{|c|c|c|c|c|c|c|}
\hline \multicolumn{7}{|c|}{ E8A1PA: Ozônio como poluente } \\
\hline \multirow[t]{2}{*}{ Turno } & \multirow{2}{*}{$\begin{array}{l}\text { Quem } \\
\text { fala? }\end{array}$} & \multirow[t]{2}{*}{ Descrição detalhada das falas } & \multirow{2}{*}{$\begin{array}{c}\text { Observações } \\
\text { contexto }\end{array}$} & \multirow{2}{*}{$\begin{array}{c}\text { Interação } \\
\text { verbal }\end{array}$} & \multicolumn{2}{|c|}{$\begin{array}{l}\text { Interação } \\
\text { cognitiva }\end{array}$} \\
\hline & & & & & O.B. & O.A. \\
\hline 1 & $\mathrm{P}$ & $\begin{array}{l}\text { "Dióxido de nitrogênio também } \\
\text { contribui para a formação de } \\
\text { ozônio na atmosfera". Vocês têm } \\
\text { a equação. E tem o seguinte, o } \\
\text { ozônio, vocês sabem que tem a } \\
\text { camada de ozônio na estratosfera. } \\
\text { Sim? }\end{array}$ & $\square$ & $\begin{array}{c}\mathrm{L} \\
\mathrm{AF} \\
\mathrm{Q}\end{array}$ & $\begin{array}{l}\text { INF } \\
\text { INF } \\
\text { QC }\end{array}$ & \\
\hline 2 & A & Sim. & ם & $\mathrm{R}$ & RI & \\
\hline 3 & $P$ & Ela é benéfica ao homem? & ם & $\mathrm{Q}$ & QF & \\
\hline 4 & A & Sim. & ם & $\mathrm{R}$ & RI & \\
\hline 5 & $\mathrm{P}$ & Por quê? & ם & $\mathrm{Q}$ & & QD \\
\hline 6 & A & (...) os raios ultravioletas. & ם & $\mathrm{R}$ & & $\mathrm{RE}$ \\
\hline 7 & $P$ & Ela controla? & $\begin{array}{l}\text { repete para } \\
\text { causar }\end{array}$ & $\mathrm{Q}$ & & QD \\
\hline
\end{tabular}




\begin{tabular}{|c|c|c|c|c|c|c|c|}
\hline & & & & $\begin{array}{l}\text { dúvida ou } \\
\text { reflexão }\end{array}$ & & & \\
\hline 8 & A & Controla. & a & & $\mathrm{R}$ & $\mathrm{RI}$ & \\
\hline 9 & $A^{\prime}$ & Filtra. & a & & $\mathrm{R}$ & RI & \\
\hline 10 & $\mathrm{P}$ & Filtra os raios ultravioletas. & $\square$ & $\begin{array}{l}\text { repete para } \\
\text { confirmar } \\
\text { uma } \\
\text { resposta } \\
\text { correta }\end{array}$ & REP & & \\
\hline 11 & A & $\begin{array}{l}\text { Não pode ser controla? Pode, não } \\
\text { pode? }\end{array}$ & a & & Q & QF & \\
\hline 12 & $\mathrm{P}$ & $\begin{array}{l}\text { Sim de certa maneira, mas ela } \\
\text { filtra, então, essa filtração é um } \\
\text { controle. }\end{array}$ & $\square$ & & $\mathrm{R}$ & & $\mathrm{RE}$ \\
\hline 13 & A & Na verdade não é controla. & 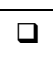 & & $\mathrm{AF}$ & INF & \\
\hline 14 & $P$ & $\begin{array}{l}\text { Sim, ela controla porque não deixa } \\
\text { passar uma grande quantidade de } \\
\text { raios ultravioleta. Sim? }\end{array}$ & $\square$ & & $\mathrm{R}$ & REF & \\
\hline 15 & $\mathrm{P}$ & $\begin{array}{l}\text { E aí, será que o ozônio na nossa } \\
\text { atmosfera é benéfico? }\end{array}$ & $\square$ & & Q & QF & \\
\hline 16 & A & É. & a & & $\mathrm{R}$ & $\mathrm{RI}$ & \\
\hline 17 & $\mathrm{P}$ & Na nossa atmosfera? & $\square$ & $\begin{array}{l}\text { repete para } \\
\text { causar } \\
\text { dúvida ou } \\
\text { reflexão }\end{array}$ & $\mathrm{Q}$ & & QD \\
\hline 18 & A & $(\ldots)$ & 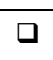 & & & & \\
\hline 19 & $P$ & $\begin{array}{l}\text { Na estratosfera a gente sabe que } \\
\text { sim. }\end{array}$ & 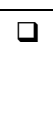 & & AF & INF & \\
\hline 20 & A & Ah, também. & $\square$ & & $\mathrm{R}$ & $\mathrm{RI}$ & \\
\hline 21 & $P$ & Também é benéfico? & a & $\begin{array}{l}\text { repete para } \\
\text { causar } \\
\text { dúvida ou } \\
\text { reflexão }\end{array}$ & Q & & QD \\
\hline 22 & A & Acho que não. & $\square$ & & $\mathrm{R}$ & $\mathrm{RI}$ & \\
\hline 23 & $P$ & Por quê? & a & & Q & & QD \\
\hline 24 & $A^{\prime}$ & Ele é considerado um poluente. & a & & $\mathrm{R}$ & $\mathrm{RI}$ & \\
\hline 25 & $A^{\prime \prime}$ & Boa pergunta! & D & & & & \\
\hline 26 & $P$ & $\begin{array}{l}\text { Será que ele tá no ambiente } \\
\text { natural dele? }\end{array}$ & $\square$ & & $\mathrm{Q}$ & QF & \\
\hline
\end{tabular}




\begin{tabular}{|c|c|c|c|c|c|}
\hline 27 & A & Não! & ם & $\mathrm{R}$ & RI \\
\hline 28 & $\mathrm{~A}^{\prime}$ & Não ta no ambiente natural dele. & a & $\mathrm{R}$ & $\mathrm{RI}$ \\
\hline 29 & $\mathrm{P}$ & $\begin{array}{l}\text { O ozônio na nossa atmosfera ele } \\
\text { é considerado um poluente. Tá? } \\
\text { Por isso que deu aí no texto a } \\
\text { seguinte informação. "Ele causa } \\
\text { irritação nos olhos e na garganta e } \\
\text { ataca folhas e vegetais". Então, na } \\
\text { nossa atmosfera ele é poluente, } \\
\text { sim ou não? }\end{array}$ & ם & $\begin{array}{c}\mathrm{AF} \\
\mathrm{Q} \\
\mathrm{L} \\
\mathrm{Q}\end{array}$ & $\begin{array}{l}\text { INF } \\
\text { QC } \\
\text { INF } \\
\text { QC }\end{array}$ \\
\hline 30 & A & Sim & Todos & $\mathrm{R}$ & $\mathrm{RI}$ \\
\hline 31 & $\mathrm{P}$ & $\begin{array}{l}\text { Então nós temos aí questões do } \\
\text { texto e eu vou estar passando } \\
\text { para vocês agora, já a } \\
\text { nomenclatura dos óxidos. Tá? A } \\
\text { gente já viu das bases, a gente já } \\
\text { viu dos ácidos e a gente vai ver } \\
\text { dos óxidos. Aí vocês já fazem os } \\
\text { exercícios do texto e de } \\
\text { nomenclatura. Certo? }\end{array}$ & ם & $\begin{array}{l}\mathrm{Q} \\
\mathrm{O} \\
\mathrm{Q}\end{array}$ & $\begin{array}{l}\mathrm{QC} \\
\mathrm{QC}\end{array}$ \\
\hline
\end{tabular}

As falas 3, 4 e 5 apresentam uma estrutura interessante (QF, RI, QD) e que já foi discutida no E4A1PA. A professora faz uma questão fechada e simples para os alunos que prontamente a respondem e, em seguida, confronta sua resposta com um pedido de explicação mais detalhada através de uma questão de desequilíbrio. Entretanto, essa estrutura, diferente do caso anterior, desencadeia uma seqüência de falas de maior valor cognitivo. Nesse caso, a QD (turno 5) dá início ao trecho desse episódio em que ocorre a maioria das interações cognitivas de alta ordem (turnos 6 a 14). Nesse trecho ocorre a negociação de significado entre a professora e um aluno que gira em torno do termo mais apropriado para designar a ação do ozônio nas altas camadas da atmosfera.

O mesmo padrão de interações (QF, RI, QD) aparece nas falas 15, 16 e 17; 15, 20 e 21 e 15, 22 e 23. Na primeira seqüência a professora não consegue uma resposta satisfatória a sua questão inicial e a questão de desequilíbrio passa ter a função de levar o aluno a repensar sua resposta e não de fazê-lo dar maiores detalhes sobre ela. Como não consegue uma resposta satisfatória novamente fornece novas informações (19) para auxiliar os estudantes a responder a questão 
inicial (15). Novamente uma resposta insatisfatória e outra questão de desequilíbrio até obter uma resposta correta (22). A questão de desequilíbrio subseqüente apresenta dessa vez a função de solicitação de aprofundamento da resposta dada.

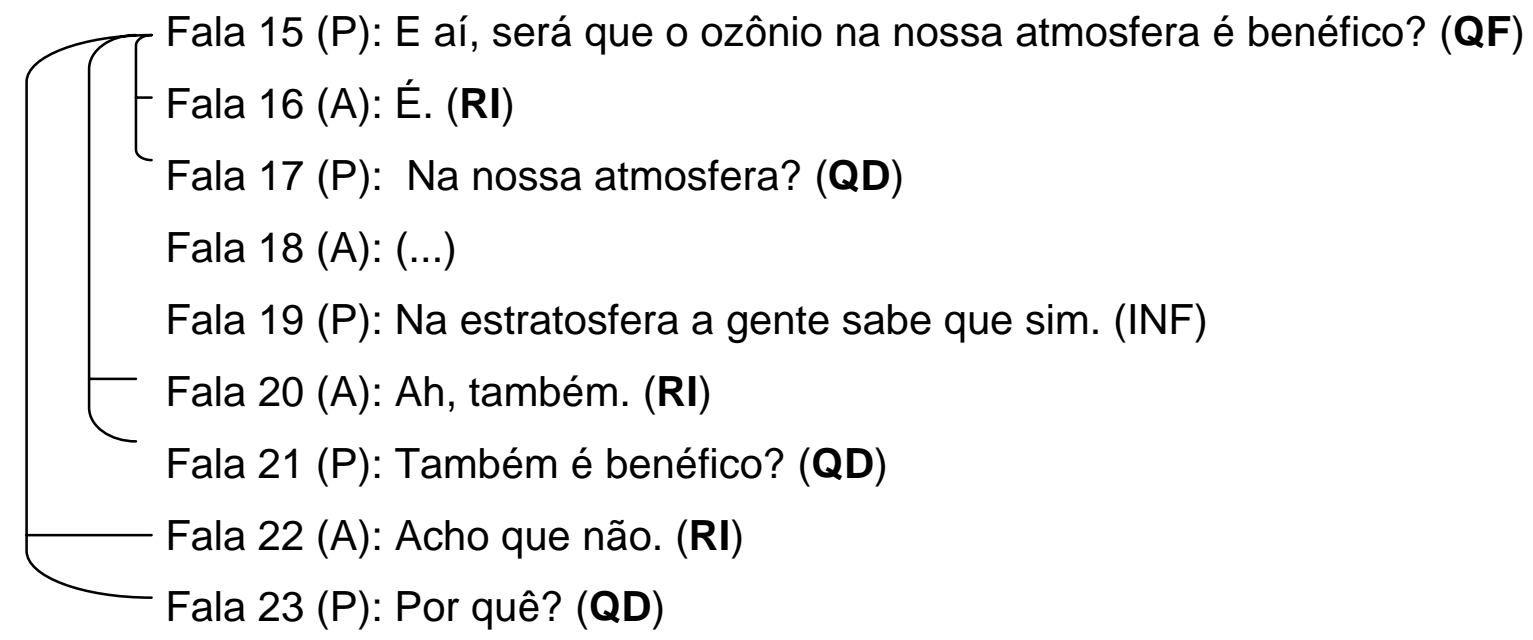

Fala $24\left(A^{\prime}\right)$ : Ele é considerado um poluente. (RI)

Parece haver os seguintes padrões de interação: QF, RI (errada), QD, RI (errada), QD, RI (errada), QD.... , ou seja, a professora continua questionando os alunos sobre suas respostas até obter uma resposta correta e, neste caso, o padrão passaria a QF, RI (certa), QD, RI ou RE (certa).

Embora esses padrões de interação possam apresentar configurações complexas como no trecho iniciado na fala 3 com a posterior negociação de significado e no trecho iniciado na fala 15 com a posterior busca da resposta correta, a estrutura inicial deles parece ser uma constante: QF, RI, QD. Essa estrutura de interação reforça a idéia discutida anteriormente de que essa tríade se trata de uma estratégia comunicativa que busca (a) promover uma maior participação dos estudantes pela simplicidade da questão fechada (quando comparado com uma questão aberta); (b) valorizar a fala do aluno dando a oportunidade de expor seu raciocínio; (c) levar o aluno a refletir sobre a resposta dada de modo a reformulá-la (se estiver incorreta) ou aprofundá-la e (d) aumentar o nível cognitivo das interações. 
Tabela 12: Distribuição das interações Verbais e Cognitivas em E8A1PA

\begin{tabular}{|c|c|c|c|c|c|}
\hline \multirow{2}{*}{\multicolumn{2}{|c|}{ Interações verbais }} & \multicolumn{4}{|c|}{ Interações Cognitivas } \\
\hline & & \multicolumn{2}{|c|}{ Ordem Baixa } & \multicolumn{2}{|c|}{ Ordem Alta } \\
\hline Categorias & $\mathrm{N}^{\circ}$ de ocorrências & CAT. & $N^{\circ}$ DE OC. & CAT. & $\mathrm{N}^{\circ} \mathrm{DE} \mathrm{OC}$ \\
\hline $\mathrm{R}$ & 14 & $\mathrm{RI}$ & 11 & QD & 5 \\
\hline Q & 14 & INF & 6 & RE & 2 \\
\hline $\mathrm{AF}$ & 4 & $\mathrm{QC}$ & 5 & & \\
\hline $\mathrm{L}$ & 2 & QF & 4 & & \\
\hline $\mathrm{O}$ & 2 & REF & 1 & & \\
\hline REP & 1 & & & & \\
\hline Total & 37 & total & 27 & total & 7 \\
\hline
\end{tabular}

\section{Análise da Aula 1 da Professora A}

A análise aqui apresentada busca dar um panorama geral do que ocorreu na aula 1 da professora A. Após a análise detalhada de cada episódio dessa aula, busca-se agora compreender, de forma mais ampla, como se deram as interações verbais e cognitivas entre a professora e os alunos.

A caracterização das interações verbais em aula pode ser feita em termos das questões e respostas que surgem nos diálogos entre professor e alunos. Essas interações verbais são aqui avaliadas considerando (a) a razão entre a quantidade de falas dos alunos e o total das falas (alunos mais professora) e (b) a razão entre a quantidade de questões e respostas e a quantidade total de interações verbais produzidas. Essa análise foi feita para cada episódio e obtiveram-se os seguintes resultados:

Tabela 13: Avaliação da Interatividade na aula 1 da professora A (A1PA) em termos das distribuições das falas de alunos e professora e das interações verbais.

\begin{tabular}{|c|c|c|c|c|c|c|c|}
\hline 1 & 2 & 3 & 4 & 5 & 6 & 7 & 8 \\
\hline $\begin{array}{l}\frac{0}{0} \\
0 \\
\frac{0}{0} \\
\frac{1}{4}\end{array}$ & 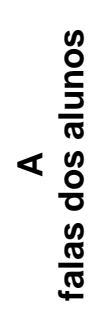 & $\begin{array}{r}\frac{1}{0} \\
\text { 0 } \\
0 \\
\frac{0}{0} \\
\frac{\pi}{\pi} \\
\frac{\pi}{\pi}\end{array}$ & 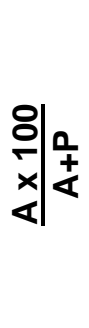 & $\begin{array}{l}\frac{r}{+} \\
\stackrel{+}{\sigma}\end{array}$ & 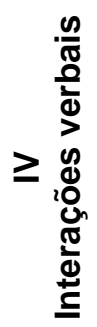 & $\begin{array}{l}\text { 임 } \\
x \\
x \\
\text { q } \\
\text { 의 }\end{array}$ & 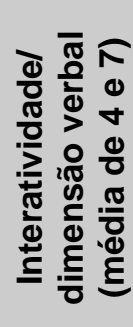 \\
\hline E1A1PA & 31 & 30 & 51 & 45 & 65 & 69 & 60 \\
\hline E2A1PA & 9 & 8 & 53 & 12 & 20 & 60 & 56 \\
\hline E3A1PA & 8 & 6 & 57 & 11 & 18 & 61 & 59 \\
\hline E4A1PA & 5 & 14 & 26 & 11 & 23 & 48 & 37 \\
\hline
\end{tabular}




\begin{tabular}{|c|c|c|c|c|c|c|c|} 
E5A1PA & 6 & 7 & 46 & 11 & 18 & 61 & 54 \\
\hline E6A1PA & 26 & 27 & 49 & 46 & 75 & 63 & 56 \\
\hline E7A1PA & 5 & 6 & 45 & 10 & 18 & 56 & 51 \\
\hline E8A1PA & 16 & 15 & 52 & 28 & 37 & 76 & 64 \\
\hline
\end{tabular}

A avaliação do nível cognitivo das aulas, ou seja, a avaliação da qualidade do discurso produzido pela professora e alunos, pode ser realizada considerando-se (a) a razão entre as interações cognitivas de alta ordem e o total de interações cognitivas geradas (somatório das interações cognitivas de alta e baixa ordem) ou (b) apenas a razão entre as questões e respostas de alta ordem cognitiva e as questões e respostas totais. Esses resultados são mostrados a seguir:

Tabela 14: Avaliação do Nível Cognitivo em A1PA em função de todas as interações cognitivas e das questões e respostas de alta e baixa ordem cognitiva.

\begin{tabular}{|c|c|c|c|c|c|c|}
\hline 1 & 2 & 3 & 4 & 5 & 6 & 7 \\
\hline $\begin{array}{l}\frac{0}{\overline{0}} \\
\frac{0}{0} \\
\text { 문 }\end{array}$ & 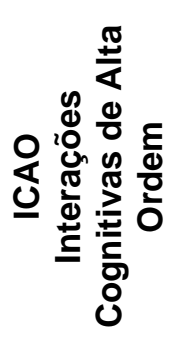 & 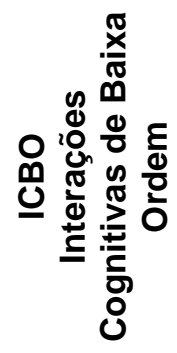 & 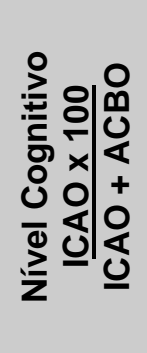 & 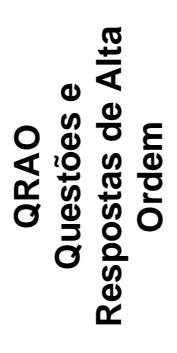 & 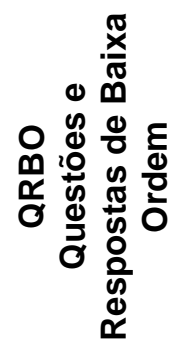 & 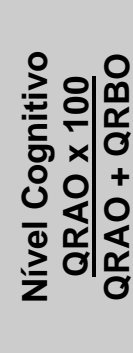 \\
\hline E1A1PA & 13 & 42 & 25 & 8 & 32 & 20 \\
\hline E2A1PA & 3 & 9 & 25 & 2 & 9 & 18 \\
\hline E3A1PA & 3 & 14 & 18 & 2 & 9 & 18 \\
\hline E4A1PA & 1 & 17 & 6 & 1 & 10 & 9 \\
\hline E5A1PA & 3 & 14 & 24 & 2 & 7 & 22 \\
\hline E6A1PA & 8 & 62 & 14 & 8 & 38 & 17 \\
\hline E7A1PA & 3 & 14 & 18 & 3 & 8 & 27 \\
\hline E8A1PA & 7 & 27 & 21 & 7 & 20 & 26 \\
\hline
\end{tabular}

Parece haver certo grau de concordância entre os resultados de Nível Cognitivo estimado a partir de todas Interações Cognitivas (coluna 4) e os resultados obtidos a partir das Questões e Respostas (coluna 7) com uma variação média de 4\% entre esses valores a cada episódio. Assim, analisando de forma qualitativa, essas diferenças parecem ser insignificantes na determinação das características gerais dessa aula. Isso pode ser observado nos gráficos a seguir, onde são apresentados esses resultados em função da interatividade. 
Gráfico 1: Caracterização da aula 1 da professora A: Aula Interativa de Baixa Ordem Cognitiva

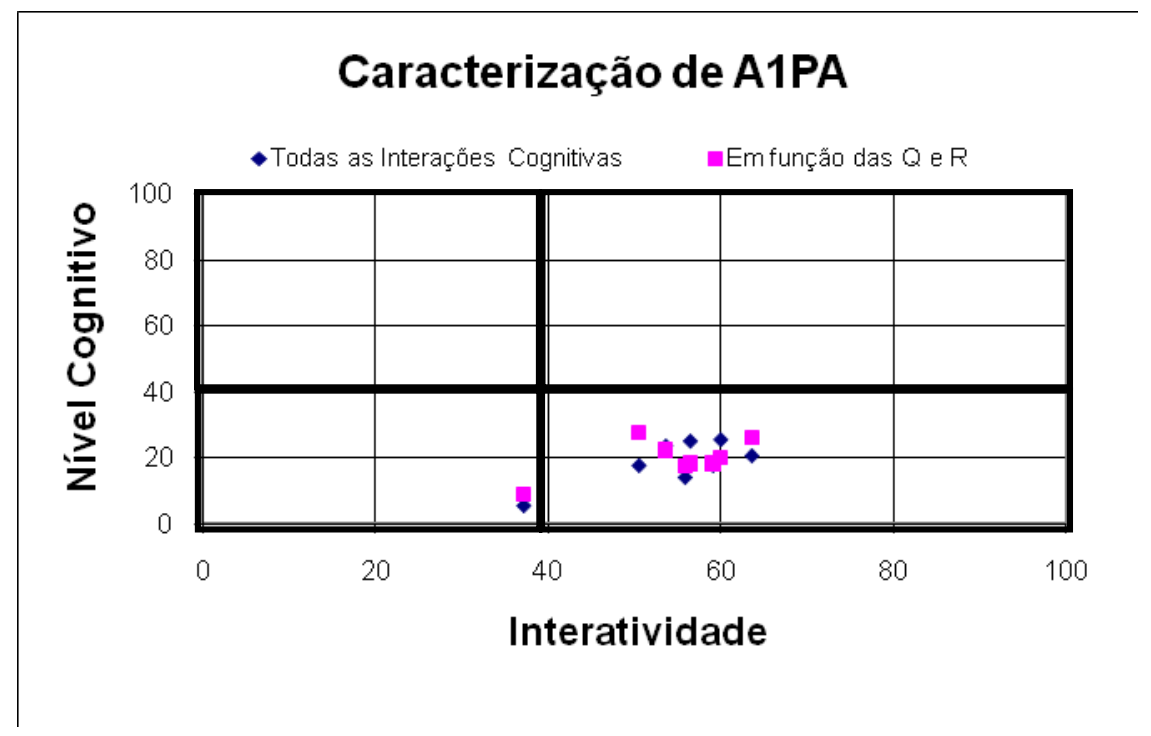

As quatro regiões demarcadas nos gráficos equivalem aos quatro possíveis estilos de aula - similares às classes de abordagens comunicativas de Mortimer e Scott (2002). Propõe-se aqui uma distribuição assimétrica das áreas por dois fatores: (a) por se considerar a importância da fala do professor de ciências, pois repousa sobre ele a incumbência de conduzir a aula, ou seja, como é esperado que o professor tenha maior número de falas em relação aos alunos, o eixo vertical que divide as regiões "interativa" (0-40) e "não-interativa" (40-100) foi deslocado para a esquerda do centro do eixo da interatividade; e (b) a necessidade intrínseca de um modelo didático de transmissão cultural em certos momentos, dependendo de quais conteúdos científicos se deseja ensinar. Mortimer e Scott consideram essas idéias ao declarar:

Faz parte do trabalho do professor intervir, introduzir novos termos e novas idéias, para fazer a estória científica avançar. Intervenções de autoridade são igualmente importantes e parte fundamental do ensino de ciências. Afinal, a linguagem social da ciência é essencialmente de autoridade.

Essas intervenções de autoridade, ou seja, intervenções do professor que "considera o que o estudante tem a dizer apenas do ponto de vista do discurso científico escolar que está sendo construído", são necessárias, em certa medida, às aulas de ciências. Alguns conceitos científicos jamais serão elaborados ou construídos pelos próprios estudantes por mais que se esforcem em refletir sobre os 
conhecimentos e informações por eles adquiridos. Nesse sentido é aceitável um maior teor de intervenções de autoridade em aulas de ciências sem prejuízos para a qualidade delas. Tais intervenções de autoridade estão fortemente relacionadas a interações cognitivas de baixa ordem (INF, QF, RI p.e.) ao passo em que intervenções dialógicas, ou seja, aquelas em que "o professor considera o que o estudante tem a dizer do ponto de vista do próprio estudante; mais de uma 'voz' é considerada e há uma inter-animação de idéias", estão mais relacionadas a interações cognitiva de alta ordem (QA, RE, SIN, ANLG, REF). Esses fatores fazem com que se torne plausível considerar aceitável um maior teor de interações cognitiva de baixa ordem, o que justifica o deslocamento para baixo do eixo horizontal que divide as quatro regiões do gráfico.

Longe de uma falsa neutralidade, propõe-se aqui um juízo de valores com relação aos quatro estilos de aula possíveis. Considera-se, de fato, de maior valor formativo para os estudantes aulas interativas de alto nível cognitivo (1), depois aulas não-interativas de alto nível cognitivo (2), aulas interativas de baixo nível cognitivo (3) e, por fim, com menor valor formativo, aulas não-interativas de baixo nível cognitivo (4), conforme a figura a seguir:

\begin{tabular}{|c|c|}
\hline $\begin{array}{l}2 \text { - Aula não- } \\
\text { interativa de alta } \\
\text { ordem cognitiva }\end{array}$ & $\begin{array}{l}1 \text { - Aula interativa de alta } \\
\text { ordem cognitiva }\end{array}$ \\
\hline $\begin{array}{l}4 \text { - Aula não- } \\
\text { interativa de baixa } \\
\text { ordem cognitiva }\end{array}$ & $\begin{array}{l}3 \text { - Aula interativa de } \\
\text { baixa ordem cognitiva }\end{array}$ \\
\hline
\end{tabular}

A primeira aula da professora A, embora possa ser considerada contextualizada por tratar de assuntos ligados ao meio ambiente (poluição atmosférica, impactos ambientais da chuva ácida), a tecnologia (consumo de combustíveis fósseis em automóveis e indústrias) e a sociedade (doenças causadas pela poluição atmosférica), não apresenta um nível de interações cognitivas satisfatório, isto é, as interações estabelecidas durante a aula entre professora e alunos pode ser considerada como de baixa ordem cognitiva. 
Por outro lado, houve um alto grau de participação dos alunos durante a aula, isto se considerarmos (a) os números de falas de alunos em relação às falas da professora e (b) o número de questões e respostas que surgiram durante a aula, como foi discutido anteriormente. De acordo com esses critérios, a aula 1 da professora A pode, então, ser considerada interativa.

Entretanto, é necessário salientar de que forma se deu essa participação dos estudantes durante a aula. Podemos destacar algumas características dessas falas:

- Em geral as falas dos estudantes foram curtas e pouco elaboradas;

- A professora buscou promover a participação dos estudantes através de questões fechadas, principalmente.

- Embora o número de falas da professora e dos alunos tenha sido muito parecido ao longo da aula, o tempo de fala da professora foi consideravelmente superior.

- Os diálogos foram conduzidos invariavelmente pela professora.

- Os estudantes se limitaram a responder as questões propostas pela professora;

- Os estudantes não trouxeram a tona assuntos que pudessem ser relacionados aos contextos discutidos em aula.

- Apenas em poucos momentos houve interações entre os próprios estudantes.

Assim, a aula 1 da professora A pode ser categorizada como interativa de baixa ordem cognitiva. Pode-se dizer, também, que a contextualização dos conhecimentos científicos, neste caso, não está relacionada a um alto nível de elaboração mental do discurso produzido em sala de aula.

\section{Episódio 1 da aula 2 da professora A (E1A2PA)}

\begin{tabular}{|c|c|c|c|c|c|c|}
\hline \multicolumn{7}{|c|}{ E1A2PA: Nomenclatura de óxidos iônicos } \\
\hline \multirow[t]{2}{*}{ Turno } & \multirow{2}{*}{$\begin{array}{l}\text { Quem } \\
\text { fala? }\end{array}$} & \multirow[t]{2}{*}{ Descrição detalhada das falas } & \multirow{2}{*}{$\begin{array}{c}\text { Observações } \\
\text { contexto }\end{array}$} & \multirow{2}{*}{$\begin{array}{c}\text { Interação } \\
\text { Verbal }\end{array}$} & \multicolumn{2}{|c|}{$\begin{array}{l}\text { Interação } \\
\text { cognitiva }\end{array}$} \\
\hline & & & & & O.B. & O.A. \\
\hline 1 & $\mathrm{P}$ & $\begin{array}{l}\text { Então nós temos aí questões do } \\
\text { texto e eu vou estar passando pra } \\
\text { vocês agora a nomenclatura dos } \\
\text { óxidos. A gente já viu dos ácidos }\end{array}$ & $\begin{array}{l}\text { escreve na } \\
\text { lousa; }\end{array}$ & $\mathrm{O}$ & & \\
\hline
\end{tabular}




\begin{tabular}{|c|c|c|c|c|c|c|}
\hline & & e das bases. & & & & \\
\hline 2 & A & Nomenclatura do quê? & a & & $\mathrm{Q}$ & QF \\
\hline 3 & $\mathrm{P}$ & $\begin{array}{l}\text { Dos óxidos (...). Então } \\
\text { acompanhem aí. Os conceitos } \\
\text { que a gente está vendo é } \\
\text { segundo Arrhenius. Então, nós } \\
\text { temos que "óxidos são compostos } \\
\text { formados apenas por dois } \\
\text { elementos químicos", onde um } \\
\text { deles tem que ser o quê? }\end{array}$ & ם & & $\begin{array}{c}\mathrm{R} \\
\mathrm{AF} \\
\mathrm{L} \\
\mathrm{Q}\end{array}$ & $\begin{array}{l}\text { RI } \\
\text { INF } \\
\text { INF } \\
\text { QF }\end{array}$ \\
\hline 4 & A & Binário (...) & a & & $\mathrm{R}$ & RI \\
\hline 5 & $\mathrm{~A}^{\prime}$ & $(\ldots)$ & ם & & & \\
\hline 6 & $P$ & $\begin{array}{l}\text { Oxigênio. Então, nós temos... } \\
\text { oxigênio com a carga dois menos } \\
\text { aí. Então, todos os óxidos terão } \\
\text { que ter um elemento } \\
\text { acompanhado do oxigênio. } \\
\text { Somente dois elementos. Quando } \\
\text { a gente ver um outro com mais, } \\
\text { eles não serão classificados como } \\
\text { óxidos. A gente vai ta vendo na } \\
\text { aula seguinte, ta? Então, a gente } \\
\text { tem aí: "Praticamente todos os } \\
\text { elementos químicos formam } \\
\text { óxidos. Dependendo da } \\
\text { eletronegatividade dos átomos as } \\
\text { ligações químicas são iônicas ou } \\
\text { covalentes". Aí a gente vai ta } \\
\text { vendo duas nomenclaturas dos } \\
\text { óxidos, uma pra ligação iônica, } \\
\text { uma pra ligação covalente. } \\
\text { Podemos ler? }\end{array}$ & & $\begin{array}{l}\text { repete a } \\
\text { resposta de } \\
\text { um aluno; } \\
\text { escreve na } \\
\text { lousa; }\end{array}$ & $\begin{array}{c}\text { REP } \\
\text { AF } \\
\text { Q } \\
\text { L } \\
\text { AF } \\
\text { Q }\end{array}$ & $\begin{array}{l}\text { INF } \\
\text { QC } \\
\text { INF } \\
\text { INF } \\
\text { QF }\end{array}$ \\
\hline 7 & A & Sim. & ב & & $\mathrm{Q}$ & RI \\
\hline 8 & $P$ & $\begin{array}{l}\text { “Óxidos iônicos". Você tem aí: } \\
\text { "Um metal mais oxigênio forma } \\
\text { óxido iônico". Vamos dar um } \\
\text { exemplo. Metais, você tem sódio, } \\
\text { cálcio, alumínio... Pessoal, se eu } \\
\text { quero a fórmula o que a gente vai } \\
\text { ter que verificar? }\end{array}$ & & $\begin{array}{l}\text { escreve na } \\
\text { lousa; }\end{array}$ & $\begin{array}{c}\mathrm{L} \\
\mathrm{AF} \\
\mathrm{Q}\end{array}$ & $\begin{array}{l}\text { INF } \\
\text { EX } \\
\text { QF }\end{array}$ \\
\hline
\end{tabular}




\begin{tabular}{|c|c|c|c|c|c|c|c|}
\hline 9 & A & A carga. & ם & & $\mathrm{R}$ & RI & \\
\hline 10 & $P$ & $\begin{array}{l}\text { A carga. Eu vou estar juntando o } \\
\text { sódio com o óxido, o oxigênio, } \\
\text { dois menos. O sódio, qual a carga } \\
\text { dele? }\end{array}$ & & $\begin{array}{l}\text { repete a } \\
\text { resposta do } \\
\text { aluno; }\end{array}$ & $\begin{array}{l}\text { REP } \\
\mathrm{AF} \\
\mathrm{Q}\end{array}$ & $\begin{array}{l}\text { INF } \\
\text { QF }\end{array}$ & \\
\hline 11 & $A$ & Um mais. & a & & $\mathrm{R}$ & RI & \\
\hline 12 & $P$ & $\begin{array}{l}\text { Um mais. Quantos sódios eu vou } \\
\text { precisar estar juntando? }\end{array}$ & व & & $\begin{array}{c}\text { REP } \\
\mathrm{Q}\end{array}$ & QF & \\
\hline 13 & A & Dois. & a & & $\mathrm{R}$ & RI & \\
\hline 14 & $\mathrm{P}$ & Por quê? & a & & $\mathrm{Q}$ & & QD \\
\hline 15 & $P$ & $(\ldots)$ & a & & & & \\
\hline 16 & $\mathrm{P}$ & $\begin{array}{l}\text { O óxido tem duas cargas } \\
\text { negativas, o sódio uma positiva. } \\
\text { Ta igual? }\end{array}$ & a & & $\begin{array}{l}\mathrm{AF} \\
\mathrm{Q}\end{array}$ & $\begin{array}{l}\text { INF } \\
\text { QF }\end{array}$ & \\
\hline 17 & $A$ & Não. & a & & $\mathrm{R}$ & RI & \\
\hline 18 & $P$ & Não. O que eu preciso? & $\square$ & $\begin{array}{l}\text { repete a } \\
\text { resposta do } \\
\text { aluno; }\end{array}$ & $\begin{array}{c}\text { REP } \\
\text { Q }\end{array}$ & QF & \\
\hline 19 & $A$ & Mais um. & प & & $\mathrm{R}$ & RI & \\
\hline 20 & $\mathrm{P}$ & Mais um... & व & $\begin{array}{l}\text { solicita que } \\
\text { completem } \\
\text { a frase; }\end{array}$ & Q & $\mathrm{CP}$ & \\
\hline 21 & A & Sódio. & $\square$ & & $\mathrm{R}$ & RI & \\
\hline 22 & $P$ & $\begin{array}{l}\text { Sódio... Como vai ficar a fórmula } \\
\text { então? }\end{array}$ & $\square$ & $\begin{array}{l}\text { repete a } \\
\text { resposta do } \\
\text { aluno; } \\
\text { escreve na } \\
\text { lousa }\end{array}$ & $\begin{array}{c}\text { REP } \\
\mathrm{Q}\end{array}$ & QF & \\
\hline 23 & A & $\mathrm{Na}_{2} \mathrm{O}$. & $\square$ & & $\mathrm{R}$ & RI & \\
\hline 24 & $P$ & $\mathrm{Na}_{2} \mathrm{O}$. & $\square$ & $\begin{array}{l}\text { repete a } \\
\text { resposta do } \\
\text { aluno; } \\
\text { escreve na } \\
\text { lousa; }\end{array}$ & REP & & \\
\hline 25 & $\mathrm{P}$ & $\begin{array}{l}\text { Percebe que as fórmulas, tanto } \\
\text { dos óxidos, dos ácidos, das bases } \\
\text { não têm necessidade de por as } \\
\text { cargas. }\end{array}$ & $\square$ & & AF & INF & \\
\hline 26 & $A$ & Tem que igualar, é? & ב & & $\mathrm{Q}$ & QF & \\
\hline 27 & $A^{\prime}$ & Não. & 口 & & $\mathrm{R}$ & RI & \\
\hline
\end{tabular}




\begin{tabular}{|c|c|c|c|c|c|c|}
\hline 28 & $P$ & $\begin{array}{l}\text { Aqui, ó! O cálcio ele é dois mais, } \\
\text { o ‘O’ é dois menos. Ta igual? Os } \\
\text { dois são iguais? }\end{array}$ & ם & $\begin{array}{l}\text { aponta para } \\
\text { a lousa; }\end{array}$ & $\mathrm{AF}$ & $\begin{array}{l}\text { INF } \\
\text { QF }\end{array}$ \\
\hline 29 & A & Sim. & $\square$ & & $\mathrm{R}$ & RI \\
\hline 30 & $P$ & Os dois são iguais? & ם & & Q & QF \\
\hline 31 & A & Sim. & 口 & & $\mathrm{R}$ & $\mathrm{RI}$ \\
\hline 32 & $P$ & $\begin{array}{l}\text { Ta, então, como fica a minha } \\
\text { fórmula? }\end{array}$ & $\square$ & & $\begin{array}{c}\mathrm{FB} \\
\mathrm{Q}\end{array}$ & $\begin{array}{l}\text { CON } \\
\text { QF }\end{array}$ \\
\hline 33 & A & Cao. & प & & $\mathrm{R}$ & $\mathrm{RI}$ \\
\hline 34 & $P$ & $\begin{array}{l}\text { CaO. Preciso de um de cada. E } \\
\text { aqui? O alumínio três mais, o } \\
\text { oxigênio dois menos. Como fica a } \\
\text { minha fórmula? }\end{array}$ & $\begin{array}{l} \\
\square\end{array}$ & $\begin{array}{l}\text { repete a } \\
\text { resposta do } \\
\text { aluno; } \\
\text { escreve na } \\
\text { lousa; }\end{array}$ & $\begin{array}{l}\text { REP } \\
\text { AF } \\
\mathrm{Q}\end{array}$ & $\begin{array}{l}\text { INF } \\
\text { QF }\end{array}$ \\
\hline 35 & A & $\mathrm{Al}_{2} \ldots$ & a & & $\mathrm{R}$ & $\mathrm{RI}$ \\
\hline 36 & $\mathrm{P}$ & Põe mais um oxigênio aqui? & $\square$ & $\begin{array}{l}\text { escreve na } \\
\text { lousa; }\end{array}$ & $\mathrm{Q}$ & QF \\
\hline 37 & A & É. & $\square$ & & $\mathrm{R}$ & $\mathrm{RI}$ \\
\hline 38 & $P$ & Três é igual a quatro? & $\square$ & & $\mathrm{Q}$ & QF \\
\hline 39 & A & Não. & $\square$ & & $\mathrm{R}$ & RI \\
\hline 40 & $\mathrm{P}$ & Mais um aqui. & व & $\begin{array}{l}\text { escreve na } \\
\text { lousa; }\end{array}$ & $\mathrm{AF}$ & INF \\
\hline 41 & A & $\begin{array}{l}\text { Põe mais um no alumínio e mais } \\
\text { um no oxigênio. }\end{array}$ & $\square$ & & $\mathrm{AF}$ & INF \\
\hline 42 & $P$ & Três, seis e quatro. & $\square$ & $\begin{array}{l}\text { Conta as } \\
\text { cargas } \\
\text { elétricas dos } \\
\text { íons; }\end{array}$ & $\mathrm{AF}$ & INF \\
\hline 43 & A & Agora um oxigênio. & a & & $\mathrm{AF}$ & INF \\
\hline 44 & $P$ & Seis e seis são iguais? & & & $\mathrm{Q}$ & QF \\
\hline 45 & A & Sim. & $\square$ & & $\mathrm{AF}$ & INF \\
\hline 46 & $P$ & $\begin{array}{l}\text { Para isso eu precisei de quantos } \\
\text { alumínios? }\end{array}$ & a & & $\mathrm{Q}$ & QF \\
\hline 47 & A & Dois! & $\square$ & & $\mathrm{R}$ & $\mathrm{RI}$ \\
\hline 48 & $P$ & E de quantos oxigênios? & a & & Q & QF \\
\hline 49 & A & Três. & a & & $\mathrm{R}$ & $\mathrm{RI}$ \\
\hline 50 & $P$ & $(\ldots)$ & $\square$ & $\begin{array}{l}\text { escreve na } \\
\text { lousa; }\end{array}$ & & \\
\hline
\end{tabular}


Tabela 15: Distribuição das interações Verbais e Cognitivas em E1A2PA

\begin{tabular}{|c|c|c|c|c|c|}
\hline \multirow{2}{*}{ Interações Verbais } & \multicolumn{4}{c|}{ Interações Cognitivas } \\
\cline { 2 - 6 } & & \multicolumn{2}{|c|}{ Ordem Baixa } & \multicolumn{2}{c|}{ Ordem Alta } \\
\hline Categoria & $\mathbf{N}^{\circ}$ de Ocorrências & CAT. & $\mathbf{N}^{\circ}$ DE OC. & CAT. & $\mathbf{N}^{\circ}$ DE OC. \\
\hline Q & 23 & QF & 19 & QD & 1 \\
\hline R & 18 & RI & 19 & & \\
\hline AF & 14 & INF & 16 & & \\
\hline REP & 7 & CON & 1 & & \\
\hline L & 3 & EX & 1 & & \\
\hline O & 1 & QC & 1 & & 1 \\
\hline FB & 1 & CP & 1 & & Total \\
\hline Total & $\mathbf{6 8}$ & Total & $\mathbf{5 9}$ & & $\mathbf{1}$ \\
\hline Distribuição das 50 falas: A:24, P:26.
\end{tabular}

\section{Episódio 2 da aula 2 da professora A (E2A2PA)}

\begin{tabular}{|c|c|c|c|c|c|c|c|}
\hline \multicolumn{8}{|c|}{ E2A2PA: Nomenclatura de Óxidos Moleculares } \\
\hline \multirow[t]{2}{*}{ Turno } & \multirow{2}{*}{$\begin{array}{l}\text { Quem } \\
\text { fala? }\end{array}$} & \multirow[t]{2}{*}{ Descrição detalhada das falas } & \multirow{2}{*}{\multicolumn{2}{|c|}{$\begin{array}{l}\text { Observações } \\
\text { contexto }\end{array}$}} & \multirow{2}{*}{$\begin{array}{c}\text { Interação } \\
\text { verbal }\end{array}$} & \multicolumn{2}{|c|}{$\begin{array}{l}\text { Interação } \\
\text { cognitiva }\end{array}$} \\
\hline & & & & & & O.B. & O.A. \\
\hline 1 & $\mathrm{P}$ & $\begin{array}{l}\text { Óxido... de... Quantos carbonos } \\
\text { tem? }\end{array}$ & & $\begin{array}{l}\text { escreve na } \\
\text { lousa; }\end{array}$ & Q & QF & \\
\hline 2 & A & Dois. & a & & $\mathrm{R}$ & $\mathrm{RI}$ & \\
\hline 3 & $P$ & Carbono?! & a & & $\mathrm{Q}$ & & QD \\
\hline 4 & $A$ & Um. & ב & & $\mathrm{R}$ & $\mathrm{RI}$ & \\
\hline 5 & $A^{\prime}$ & É um. & a & & $\mathrm{R}$ & RI & \\
\hline 6 & $\mathrm{P}$ & $\begin{array}{l}\text { Quando você tem um do } \\
\text { elemento que tá acompanhando o } \\
\text { óxido, você pode, é opcional } \\
\text { colocar o ‘mono'. Aqui. Quantos } \\
\text { óxidos tem? }\end{array}$ & & $\begin{array}{l}\text { escreve na } \\
\text { lousa; }\end{array}$ & $\begin{array}{l}\text { AF } \\
Q\end{array}$ & $\begin{array}{l}\text { INF } \\
\text { QF }\end{array}$ & \\
\hline 7 & $A$ & Um! & $\square$ & & $\mathrm{R}$ & $\mathrm{RI}$ & \\
\hline 8 & $\mathrm{P}$ & Um. Um é... & & $\begin{array}{l}\text { repete a } \\
\text { resposta do } \\
\text { aluno; } \\
\text { solicita que } \\
\text { completem } \\
\text { a frase; }\end{array}$ & $\begin{array}{c}\text { REP } \\
\mathrm{Q}\end{array}$ & $\mathrm{CP}$ & \\
\hline 9 & A & Mono. & $\square$ & & $\mathrm{R}$ & $\mathrm{RI}$ & \\
\hline 10 & $P$ & Você pode tirar? & $\square$ & & $\mathrm{Q}$ & QF & \\
\hline 11 & A & Não. & a & & $\mathrm{R}$ & RI & \\
\hline 12 & $P$ & Não posso. & a & & REP & & \\
\hline 13 & A & Sabia! & a & & AF & INF & \\
\hline
\end{tabular}




\begin{tabular}{|c|c|c|c|c|c|c|}
\hline 14 & $\mathrm{P}$ & $\begin{array}{l}\text { Este é opcional. } \mathrm{E} \text { o } \mathrm{SO}_{2} \text { que } \\
\text { vocês já conhecem? }\end{array}$ & $\square$ & $\begin{array}{l}\text { aponta para } \\
\text { a lousa; }\end{array}$ & $\begin{array}{l}\mathrm{AF} \\
\mathrm{Q}\end{array}$ & $\begin{array}{l}\text { INF } \\
\text { QF }\end{array}$ \\
\hline 15 & $A$ & Dióxido (...) & a & & $\mathrm{R}$ & RI \\
\hline 16 & $\mathrm{P}$ & $\begin{array}{l}\text { Dióxido... de... mono... O que é } \\
\text { 'S'? }\end{array}$ & $\square$ & $\begin{array}{l}\text { escreve na } \\
\text { lousa; }\end{array}$ & $\begin{array}{l}\text { REP } \\
\text { Q }\end{array}$ & QF \\
\hline 17 & $A$ & $(\ldots)$ & a & & & \\
\hline 18 & $\mathrm{P}$ & $\begin{array}{l}\text { Enxofre. Pega um outro diferente } \\
\text { aqui. E aqui? }\end{array}$ & $\begin{array}{l} \\
\square \\
0\end{array}$ & $\begin{array}{l}\text { escreve na } \\
\text { lousa; } \\
\text { escreve } \\
\text { " } \mathrm{P}_{2} \mathrm{O}_{5} \text { "; }\end{array}$ & $\begin{array}{l}\text { AF } \\
Q\end{array}$ & $\begin{array}{l}\text { INF } \\
\text { QF }\end{array}$ \\
\hline 19 & A & Di... & $\square$ & & $\mathrm{R}$ & RI \\
\hline 20 & $\mathrm{P}$ & Quantos óxidos tem aí? & $\square$ & & Q & QF \\
\hline 21 & A & Dois. & $\square$ & & $\mathrm{R}$ & RI \\
\hline 22 & $A^{\prime}$ & Três. & $\square$ & & $\mathrm{R}$ & $\mathrm{RI}$ \\
\hline 23 & $A^{\prime \prime}$ & Um. & a & & $\mathrm{R}$ & RI \\
\hline 24 & A & Cinco! Nossa, não to enxergando. & $\square$ & & $\mathrm{R}$ & RI \\
\hline 25 & $A^{\prime}$ & É pentaaaa! & $\square$ & risos; & $\mathrm{AF}$ & INF \\
\hline 26 & A & Pentóxido! & $\square$ & & $\mathrm{R}$ & $\mathrm{RI}$ \\
\hline 27 & $\mathrm{P}$ & Pentóxido. De... & $\begin{array}{l} \\
\\
\end{array}$ & $\begin{array}{l}\text { repete a fala } \\
\text { do alunos; } \\
\text { solicita que } \\
\text { complete a } \\
\text { frase; }\end{array}$ & $\begin{array}{c}\text { REP } \\
\text { Q }\end{array}$ & $\mathrm{CP}$ \\
\hline 28 & A & Difósforo. & $\square$ & & $\mathrm{R}$ & RI \\
\hline 29 & $A^{\prime}$ & Difósforo! & $\square$ & & $\mathrm{R}$ & RI \\
\hline 30 & $P$ & $\begin{array}{l}\text { Você tem aí, agora, três } \\
\text { exercícios para resolver. }\end{array}$ & $\square$ & $\begin{array}{l}\text { escreve na } \\
\text { lousa; }\end{array}$ & $\mathrm{O}$ & \\
\hline
\end{tabular}

Tabela 16: Distribuição das interações Verbais e Cognitivas em E2A2PA

\begin{tabular}{|c|c|c|c|c|c|}
\hline \multirow{2}{*}{ Interações Verbais } & \multicolumn{4}{c|}{ Interações Cognitivas } \\
\cline { 2 - 6 } & & \multicolumn{2}{|c|}{ Ordem Baixa } & \multicolumn{2}{c|}{ Ordem Alta } \\
\hline Categoria & $\mathbf{N}^{\circ}$ de Ocorrências & CAT. & $\mathbf{N}^{\circ}$ DE OC. & CAT. & $\mathbf{N}^{\circ}$ DE OC. \\
\hline $\mathrm{R}$ & 15 & RI & 15 & QD & 1 \\
\hline $\mathrm{Q}$ & 10 & QF & 7 & & \\
\hline $\mathrm{AF}$ & 5 & INF & 5 & & \\
\hline $\mathrm{REP}$ & 4 & $\mathrm{QR}$ & 1 & & \\
\hline O & 1 & CP & 2 & & 1 \\
\hline total & $\mathbf{3 5}$ & total & $\mathbf{3 0}$ & Total & $\mathbf{1}$ \\
\hline Distribuição das 30 falas: A:18, P:12.
\end{tabular}

Os episódios 1 e 2 dessa segunda aula da professora A mostram uma nítida diferença com relação ao que foi visto na aula anterior. Aqui o conteúdo da aula gira 
em torno do tema "nomenclatura de óxidos". O discurso construído pela a professora e pelos alunos mostra novamente uma grande interatividade causada por um grande número questões e respostas e pela grande parcela de falas emitidas pelos alunos. Vale a pena frisar, entretanto, que a qualidade desse discurso, do ponto de vista das interações cognitivas, é inferior ao que foi observado na aula anterior. Predominam aqui interações cognitivas de baixa ordem, sobretudo questões fechadas e respostas informativas.

A queda no nível cognitivo das interações possivelmente está relacionada ao tipo de conteúdo tratado nesses episódios. O tópico "nomenclatura de óxido" não favorece o uso de interações cognitivas de alta ordem por exigir da professora e dos alunos apenas que se conheçam as fórmulas das espécies químicas, suas cargas elétricas e a necessidade de se igualar as cargas elétricas positivas e negativas nas fórmulas.

\section{Episódio 3 da aula 2 da professora A (E3A2PA)}

\begin{tabular}{|c|c|c|c|c|c|c|}
\hline \multicolumn{7}{|c|}{ E3A2PA: Os Óxidos e a Chuva Ácida } \\
\hline \multirow[t]{2}{*}{ Turno } & \multirow{2}{*}{$\begin{array}{l}\text { Quem } \\
\text { fala? }\end{array}$} & \multirow[t]{2}{*}{ Descrição detalhada das falas } & \multirow{2}{*}{$\begin{array}{c}\text { Observações } \\
\text { contexto }\end{array}$} & \multirow{2}{*}{$\begin{array}{c}\text { Interação } \\
\text { verbal }\end{array}$} & \multicolumn{2}{|c|}{$\begin{array}{l}\text { Interação } \\
\text { cognitiva }\end{array}$} \\
\hline & & & & & O.B. & O.A. \\
\hline 1 & $P$ & $\begin{array}{l}\text { "A interação entre a água da } \\
\text { chuva e o gás carbônico deixa } \\
\text { a chuva ligeiramente ácida, já } \\
\text { que se trata de um ácido fraco. } \\
\text { Essa acidez natural da chuva é } \\
\text { tão baixa que"... Que o quê? }\end{array}$ & $\begin{array}{l}\text { solicita que } \\
\text { completem } \\
\text { a frase. }\end{array}$ & $\begin{array}{l}\mathrm{L} \\
\mathrm{Q}\end{array}$ & $\begin{array}{l}\text { INF } \\
\text { QF }\end{array}$ & \\
\hline 2 & A & $\begin{array}{l}\text { Não causa nenhum dano aos } \\
\text { seres vivos. }\end{array}$ & $\square$ & $\mathrm{R}$ & $\mathrm{RI}$ & \\
\hline 3 & $\mathrm{P}$ & $\begin{array}{l}\text { Isso! Então, esta é a primeira. } \\
\text { A chuva em ambiente não } \\
\text { poluído é ligeiramente ácida } \\
\text { devido a presença de que } \\
\text { então? }\end{array}$ & $\square$ & $\begin{array}{l}\mathrm{FB} \\
\mathrm{Q}\end{array}$ & $\begin{array}{l}\text { CON } \\
\text { QF }\end{array}$ & \\
\hline 4 & A & $(\ldots)$ & 口 & & & \\
\hline 5 & $P$ & Hem? É ligeiramente ácida por & D & $\mathrm{Q}$ & & QA \\
\hline
\end{tabular}




\begin{tabular}{|c|c|c|c|c|c|c|}
\hline & & quê? & & & & \\
\hline 6 & $A^{\prime}$ & $(\ldots)$ & 口 & & & \\
\hline 7 & $P$ & Dúvidas aí? & $\square$ & $\mathrm{Q}$ & QC & \\
\hline 8 & $A$ & Não. & 口 & $\mathrm{R}$ & RI & \\
\hline 9 & $P$ & $\begin{array}{l}\text { "B. A concentração de gás } \\
\text { carbônico na atmosfera tem } \\
\text { aumentado nos últimos anos. } \\
\text { Cite uma conseqüência } \\
\text { ambiental principal". E aí? }\end{array}$ & $\square$ & $\begin{array}{l}\mathrm{L} \\
\mathrm{C}\end{array}$ & INF & QA \\
\hline 10 & $A$ & $\begin{array}{l}\text { Ah, a camada de ozônio (...). } \\
\text { Ah, nada a ver... }\end{array}$ & $\square$ & $\begin{array}{l}\mathrm{R} \\
\mathrm{AF}\end{array}$ & $\begin{array}{l}\text { RI } \\
\text { DIS }\end{array}$ & \\
\hline 11 & $A^{\prime}$ & Vai saber. & $\square$ & & & \\
\hline 12 & $A^{\prime \prime}$ & Aumenta a poluição. & $\square$ & $\mathrm{R}$ & RI & \\
\hline 13 & $P$ & E aí? & 口 & C & & \\
\hline 14 & A & $\begin{array}{l}\text { O aumento do número de } \\
\text { veículos. Tem a ver } \\
\text { professora? }\end{array}$ & $\square$ & $\begin{array}{l}\mathrm{R} \\
\mathrm{Q}\end{array}$ & $\begin{array}{l}\text { RI } \\
\text { QF }\end{array}$ & \\
\hline 15 & $P$ & $\begin{array}{l}\text { Não. Uma conseqüência } \\
\text { ambiental?! }\end{array}$ & $\square$ & $\begin{array}{l}\text { FB } \\
\text { REP }\end{array}$ & DIS & \\
\hline 16 & $A$ & Não... tá bom... & 口 & & & \\
\hline 17 & $A^{\prime}$ & $\begin{array}{l}\text { O que acontece quando a } \\
\text { gente descarta? }\end{array}$ & $\square$ & Q & QF & \\
\hline 18 & $P$ & $\begin{array}{l}\text { O que que acontece com o } \\
\text { aumento da concentração de } \\
\text { gás carbônico? Aí no texto } \\
\text { tem. Vocês já sabem. E aí? } \\
\text { (...) E aí? }\end{array}$ & 口 & $\begin{array}{l}\text { Q } \\
\text { AF } \\
\text { C }\end{array}$ & $\begin{array}{l}\text { QF } \\
\text { INF }\end{array}$ & \\
\hline 19 & A & $(\ldots)$ & $\square$ & & & \\
\hline 20 & $P$ & $\begin{array}{l}\text { Conseqüência ao meio } \\
\text { ambiente. Oh, pessoal, } \\
\text { prestem atenção! Letra 'C'. "O } \\
\text { que podemos afirmar sobre o } \\
\text { cheiro e a cor do monóxido de } \\
\text { carbono"? }\end{array}$ & $\square$ & $\begin{array}{l}\text { AF } \\
\mathrm{O} \\
\mathrm{Q}\end{array}$ & $\begin{array}{l}\text { INF } \\
\text { QF }\end{array}$ & \\
\hline 21 & A & $\begin{array}{l}\text { Ah, não tem cheiro e não tem } \\
\text { cor, por isso é muito perigoso. }\end{array}$ & $\square$ & $\mathrm{R}$ & & $\mathrm{RE}$ \\
\hline
\end{tabular}




\begin{tabular}{|c|c|c|c|c|c|c|}
\hline 22 & $P$ & $\begin{array}{l}\text { Isso! Então, sua presença na } \\
\text { atmosfera traz algum } \\
\text { problema? }\end{array}$ & $\square$ & $\begin{array}{l}\mathrm{FB} \\
\mathrm{Q}\end{array}$ & $\begin{array}{l}\mathrm{CON} \\
\mathrm{QF}\end{array}$ & \\
\hline 23 & $A$ & Sim! & $\square$ & $\mathrm{R}$ & $\mathrm{RI}$ & \\
\hline 24 & $\mathrm{P}$ & Qual? & $\square$ & $\mathrm{Q}$ & & QD \\
\hline 25 & $\overline{A^{\prime}}$ & Pode dar dor de cabeça. & a & $\mathrm{R}$ & RI & \\
\hline 26 & $A^{\prime \prime}$ & $\begin{array}{l}\text { Pode levar até a morte se } \\
\text { estiver em lugar fechado. }\end{array}$ & $\square$ & $\mathrm{R}$ & RI & \\
\hline 27 & $A^{\prime}$ & $(\ldots)$ & $\square$ & & & \\
\hline 28 & $P$ & $\begin{array}{l}\text { Dúvida aí com relação ao } \\
\text { monóxido? "D. Cite três } \\
\text { conseqüências da chuva } \\
\text { ácida". Aí você tem... Quais } \\
\text { vocês lembram? }\end{array}$ & $\square$ & $\begin{array}{l}\mathrm{Q} \\
\mathrm{L} \\
\mathrm{Q}\end{array}$ & $\begin{array}{l}\text { QC } \\
\text { QF }\end{array}$ & \\
\hline 29 & A & $\begin{array}{l}\text { Prejudica a vegetação, os } \\
\text { peixes na água, o solo. }\end{array}$ & $\square$ & $\mathrm{R}$ & RI & \\
\hline 30 & $\mathrm{P}$ & O solo. & a - Repete & REP & & \\
\hline 31 & $A^{\prime}$ & A água dos rios. & 口 & $\mathrm{R}$ & $\mathrm{RI}$ & \\
\hline 32 & $P$ & $\begin{array}{l}\text { Sei que tem mais... é só pra } \\
\text { citar três. Dúvidas aí? Letra 'E'. } \\
\text { "Óxidos de nitrogênio quando } \\
\text { presentes na atmosfera } \\
\text { aumentam a acidez da água. } \\
\text { Cite duas origens possíveis } \\
\text { destes óxidos e explique como } \\
\text { o ácido nítrico aparece na } \\
\text { chuva”. }\end{array}$ & प & $\begin{array}{l}\mathrm{AF} \\
\mathrm{Q} \\
\mathrm{L}\end{array}$ & $\begin{array}{l}\text { INF } \\
\text { QC } \\
\text { INF }\end{array}$ & $\mathrm{QA}$ \\
\hline 33 & A & $(\ldots)$ & $\square$ & & & \\
\hline 34 & $\mathrm{P}$ & $\begin{array}{l}\text { Primeiro, os óxidos... ah... } \\
\text { Qual a origem destes óxidos? } \\
\text { Duas origens, gente. }\end{array}$ & $\square$ & $\begin{array}{c}\mathrm{Q} \\
\mathrm{AF}\end{array}$ & $\begin{array}{l}\text { QF } \\
\text { INF }\end{array}$ & \\
\hline 35 & A & Os raios. & $\square$ & $\mathrm{R}$ & RI & \\
\hline 36 & $P$ & $\begin{array}{l}\text { Através da presença dos raios } \\
\text { da chuva. E outra? }\end{array}$ & 口 paráfrase & $\begin{array}{l}\mathrm{AF} \\
\mathrm{Q}\end{array}$ & $\begin{array}{l}\text { PAR } \\
\text { QF }\end{array}$ & \\
\hline 37 & $A^{\prime}$ & Os motores. & a & $\mathrm{R}$ & $\mathrm{RI}$ & \\
\hline 38 & $A^{\prime \prime}$ & Combustão & $\square$ & $\mathrm{R}$ & $\mathrm{RI}$ & \\
\hline
\end{tabular}




\begin{tabular}{|c|c|c|c|c|c|c|}
\hline 39 & $P$ & $\begin{array}{l}\text { O que acontece nos motores, } \\
\text { lá... que a gente ouviu falar? }\end{array}$ & $\square$ & $\mathrm{Q}$ & & QA \\
\hline 40 & A & $\begin{array}{l}\text { Combustão... é... solta fumaça } \\
\text { lá. }\end{array}$ & $\square$ & $\mathrm{R}$ & RI & \\
\hline 41 & $P$ & Não. O nitrogênio? & $\square$ & $\begin{array}{c}\mathrm{FB} \\
\mathrm{Q}\end{array}$ & $\begin{array}{l}\text { DIS } \\
\text { QF }\end{array}$ & \\
\hline 42 & $A^{\prime}$ & Queima. & 口 & $\mathrm{R}$ & RI & \\
\hline 43 & $P$ & A queima de quem? & $\square$ & $\mathrm{Q}$ & QF & \\
\hline 44 & A & Do nitrogênio. & $\square$ & $\mathrm{R}$ & $\mathrm{RI}$ & \\
\hline 45 & $P$ & $\begin{array}{l}\text { Dentro dos motores o oxigênio } \\
\text { vai se juntar com os outros } \\
\text { gases e formam os óxidos de } \\
\text { nitrogênio. }\end{array}$ & a & AF & INF & \\
\hline 46 & A & $(\ldots)$ & $\square$ & & & \\
\hline 47 & $P$ & $\begin{array}{l}\text { A pergunta é a seguinte: } \\
\text { Como, então, aparece o ácido } \\
\text { nítrico na chuva? Os óxidos de } \\
\text { nitrogênio se juntam com a } \\
\text { água da chuva formando... }\end{array}$ & a completem & $\begin{array}{l}\mathrm{Q} \\
\mathrm{Q}\end{array}$ & $\begin{array}{l}\mathrm{QR} \\
\mathrm{CP}\end{array}$ & \\
\hline 48 & A & A chuva ácida. & $\square$ & $\mathrm{R}$ & $\mathrm{RI}$ & \\
\hline 49 & $P$ & $\begin{array}{l}\text { A chuva ácida. Oh, pessoal, } \\
\text { prestem atenção! }\end{array}$ & $\begin{array}{l}\text { repete a fala } \\
\text { do aluno }\end{array}$ & $\begin{array}{c}\text { REP } \\
\text { O }\end{array}$ & & \\
\hline
\end{tabular}

Nesse episódio há uma ligeira melhora no nível cognitivo da aula em relação aos dois outros episódios dessa aula. Essa pequena mudança pode ser percebida pela ocorrência de um maior número de interações cognitivas de alta ordem, como é mostrado na tabela a seguir. 
Tabela 17: Distribuição das interações Verbais e Cognitivas em E3A2PA

\begin{tabular}{|c|c|c|c|c|c|}
\hline \multirow{2}{*}{\multicolumn{2}{|c|}{ Interações Verbais }} & \multicolumn{4}{|c|}{ Interações Cognitivas } \\
\hline & & \multicolumn{2}{|c|}{ Ordem Baixa } & \multicolumn{2}{|c|}{ Ordem Alta } \\
\hline Categoria & $\mathrm{N}^{\circ}$ de Ocorrências & CAT. & $\mathrm{N}^{\circ}$ DE OC. & CAT. & $\mathrm{N}^{\circ} \mathrm{DE}$ OC \\
\hline $\mathrm{Q}$ & 20 & $\mathrm{RI}$ & 17 & QA & 4 \\
\hline $\mathrm{R}$ & 18 & QF & 12 & $\mathrm{RE}$ & 1 \\
\hline $\mathrm{AF}$ & 7 & INF & 8 & QD & 1 \\
\hline $\mathrm{L}$ & 4 & DIS & 3 & & \\
\hline FB & 4 & $\mathrm{QC}$ & 3 & & \\
\hline REP & 3 & $\mathrm{CON}$ & 2 & & \\
\hline $\mathrm{C}$ & 3 & PAR & 1 & & \\
\hline \multirow[t]{2}{*}{$\mathrm{O}$} & 2 & $\mathrm{CP}$ & 1 & & \\
\hline & & QR & 1 & & \\
\hline Total & 61 & total & 48 & Total & 6 \\
\hline
\end{tabular}

Parece haver uma relação entre essa melhora e o conteúdo abordado ao longo desse episódio. As falas da professora e dos alunos giram em torno dos processos de formação de poluentes atmosféricos e da formação de chuva ácida, ou seja, o conteúdo aqui é contextualizado, diferentemente do que aconteceu nos episódios anteriores onde o assunto era nomenclatura de óxidos. Embora as interações ocorram sendo guiadas pela atividade (correção de um questionário), assim como o foi nos episódios anteriores, nesse caso as questões foram exploradas um pouco mais, promovendo uma pequena melhora no nível cognitivo da aula.

Contudo, é preciso notar que alguns pontos negativos nas interações ainda persistem tal qual foi observado na aula anterior. Dentre eles, pode-se destacar o fato de que a maioria das interações de alta ordem estão associadas à professora; as respostas dos alunos são quase sempre pouco elaboradas; e a professora invariavelmente é quem dirige o processo.

\section{Episódio 4 da aula 2 da professora A (E4A2PA)}

\begin{tabular}{|c|c|c|c|c|c|c|}
\hline \multicolumn{7}{|c|}{ E4A2PA: Exercícios de Nomenclatura de Óxidos Metálicos } \\
\hline \multirow[t]{2}{*}{ Turno } & \multirow{2}{*}{$\begin{array}{l}\text { Quem } \\
\text { fala? }\end{array}$} & \multirow[t]{2}{*}{ Descrição detalhada das falas } & \multirow{2}{*}{$\begin{array}{c}\text { Observações } \\
\text { contexto }\end{array}$} & \multirow{2}{*}{$\begin{array}{c}\text { Interação } \\
\text { verbal }\end{array}$} & \multicolumn{2}{|c|}{$\begin{array}{l}\text { Interação } \\
\text { cognitiva }\end{array}$} \\
\hline & & & & & O.B. & O.A. \\
\hline 1 & $P$ & $\begin{array}{l}\text { O segundo exercício é pra dar } \\
\text { o nome aos óxidos metálicos. } \\
\text { Então, vamos lá. Letra 'a'. }\end{array}$ & $\square$ & O & & \\
\hline
\end{tabular}




\begin{tabular}{|c|c|c|c|c|c|}
\hline 2 & $A$ & 'A' de amor, 'B' de baixinho... & $\square$ & & \\
\hline 3 & $P$ & SnO, como fica? & ב Escreve & $\mathrm{Q}$ & QF \\
\hline 4 & $A$ & $(\ldots)$ & $\square$ & & \\
\hline 5 & $P$ & $\begin{array}{l}\text { Óxido de estanho. Precisa } \\
\text { colocar a carga dele? Sim ou } \\
\text { não? }\end{array}$ & $\begin{array}{l}\text { repete a fala } \\
\text { de um aluo } \\
\text { Escreve }\end{array}$ & $\begin{array}{c}\text { REP } \\
\text { Q }\end{array}$ & QF \\
\hline 6 & $A$ & Não. & $\square$ & $\mathrm{R}$ & $\mathrm{RI}$ \\
\hline 7 & $P$ & E aí? & व & C & \\
\hline 8 & A & $(\ldots)$ & $\square$ & & \\
\hline 9 & $\mathrm{P}$ & $\begin{array}{l}\text { Na aula passada vocês viram } \\
\text { que o estanho tem duas } \\
\text { cargas possíveis, então } \\
\text { precisa. }\end{array}$ & $\square$ & AF & INF \\
\hline 10 & $A$ & SnO. & $\square$ & AF & INF \\
\hline 11 & $P$ & $\begin{array}{l}\text { E aí? Qual será a carga deste } \\
\text { estanho aí? }\end{array}$ & $\square$ & $\begin{array}{l}\mathrm{C} \\
\mathrm{Q}\end{array}$ & QF \\
\hline 12 & $A$ & É um. & $\square$ & $\mathrm{R}$ & $\mathrm{RI}$ \\
\hline 13 & $\mathrm{P}$ & Óxido é dois menos. & $\square$ & AF & INF \\
\hline 14 & $A$ & Então é menos dois. & $\square$ & $\mathrm{AF}$ & REF \\
\hline 15 & $P$ & $\mathrm{BaO} ?$ & $\square$ & Q & QF \\
\hline 16 & $A$ & $\begin{array}{l}\text { Óxido de bário. Eu ia falar } \\
\text { 'barro'... }\end{array}$ & $\square$ & $\mathrm{R}$ & RI \\
\hline 17 & $P$ & $\mathrm{Ag}_{2} \mathrm{O} ?$ & $\square$ & $\mathrm{Q}$ & QF \\
\hline 18 & $A$ & $\begin{array}{l}\text { Óxido de (...). la falar errado, } \\
\text { carbono é o de baixo. }\end{array}$ & $\square$ & $\mathrm{R}$ & RI \\
\hline 19 & $A^{\prime}$ & Óxido de prata. & $\square$ & $\mathrm{R}$ & $\mathrm{RI}$ \\
\hline 20 & $P$ & $\mathrm{CoO} ?$ & $\square$ & Q & QF \\
\hline 21 & $A^{\prime \prime}$ & Óxido de carbono. & $\square$ & $\mathrm{R}$ & $\mathrm{RI}$ \\
\hline 22 & $P$ & Não é carbono. & $\square$ & FB & DIS \\
\hline 23 & $A$ & Cobalto. & $\square$ & $\mathrm{R}$ & $\mathrm{RI}$ \\
\hline 24 & $P$ & Cobalto! & a Repete & REP & \\
\hline 25 & $A^{\prime \prime}$ & Cobalto?! A culpa é do (...). & $\square$ & $\mathrm{Q}$ & QR \\
\hline 26 & $P$ & $\mathrm{~Pb} ?$ & $\square$ & $\mathrm{Q}$ & QF \\
\hline 27 & $A$ & Chumbo. & $\square$ & $\mathrm{R}$ & $\mathrm{RI}$ \\
\hline 28 & $A^{\prime}$ & Chumbo. & $\square$ & REP & \\
\hline 29 & $P$ & CuO? & $\square$ & $\mathrm{Q}$ & QF \\
\hline
\end{tabular}




\begin{tabular}{|c|c|c|c|c|c|}
\hline 30 & $A$ & CuO? & $\square$ & Q & QR \\
\hline 31 & $A^{\prime}$ & É cobre. & Q & $\mathrm{R}$ & $\mathrm{RI}$ \\
\hline 32 & $A^{\prime \prime}$ & $\begin{array}{l}\text { Não, não, não. É óxido de } \\
\text { cobre. }\end{array}$ & $\square$ & $\begin{array}{l}\text { FB } \\
\text { AF }\end{array}$ & $\begin{array}{l}\text { DIS } \\
\text { REF }\end{array}$ \\
\hline 33 & $P$ & Qual? & $\square$ & $\mathrm{Q}$ & QF \\
\hline 34 & $\mathrm{~A}$ & $\begin{array}{l}\text { A 'g' também é óxido de cobre, } \\
\text { só que é dois (...) Não! A de } \\
\text { baixo! }\end{array}$ & $\square$ & $A F$ & INF \\
\hline 35 & $P$ & Veja bem... Porque... & $\begin{array}{ll}\text { Escreve } \\
\end{array}$ & & \\
\hline 36 & $A$ & $(\ldots)$ & $\square$ & & \\
\hline 37 & $A^{\prime}$ & $\begin{array}{l}\text { (...) ah, é pegadinha! não vale } \\
\text { não. }\end{array}$ & $\square$ & & \\
\hline 38 & $P$ & Como fica o ‘h'? Óxido de... & $\begin{array}{ll}\text { C } & \text { Completem }\end{array}$ & $\begin{array}{l}\mathrm{Q} \\
\mathrm{Q}\end{array}$ & $\begin{array}{l}\text { QF } \\
\mathrm{CP}\end{array}$ \\
\hline 39 & A & Alumínio. & $\square$ & $\mathrm{R}$ & RI \\
\hline 40 & $A^{\prime}$ & $\begin{array}{l}\text { É o alumínio que faz a panela } \\
\text { da minha mãe. }\end{array}$ & Q & $A F$ & INF \\
\hline 41 & $A^{\prime \prime}$ & Zinco, Zinco, Zinco. & प & $\mathrm{AF}$ & INF \\
\hline 42 & $A^{\prime}$ & $\begin{array}{l}\text { Escreve lá em cima, } \\
\text { professora, senão a gente não } \\
\text { enxerga daqui. Tem muitos } \\
\text { alunos na sala. }\end{array}$ & प & $\mathrm{O}$ & \\
\hline 43 & $P$ & 'l’? & $\square$ & $\mathrm{Q}$ & QF \\
\hline 44 & $\mathrm{~A}$ & Óxido de zinco. & प & $\mathrm{R}$ & RI \\
\hline 45 & $\mathrm{P}$ & Óxido de zinco. 'J'? & $\begin{array}{ll} & \text { - Escreve } \\
\square & \text { - repete }\end{array}$ & $\begin{array}{c}\text { REP } \\
\mathrm{Q}\end{array}$ & QF \\
\hline 46 & $\mathrm{~A}$ & $\begin{array}{l}\text { Óxido de cálcio! Tem que por o } \\
\text { ‘óxido' antes. }\end{array}$ & a & $\begin{array}{c}\mathrm{R} \\
\mathrm{AF}\end{array}$ & $\begin{array}{l}\mathrm{RI} \\
\mathrm{INF}\end{array}$ \\
\hline 47 & $A^{\prime}$ & $\begin{array}{l}\text { Por que ela fala mais alto que } \\
\text { todo mundo? }\end{array}$ & $\square$ & & \\
\hline 48 & $A^{\prime \prime}$ & Porque ela quer aparecer. & Q & & \\
\hline 49 & $A$ & $\begin{array}{l}\text { Não. Porque eu quero ganhar } \\
\text { nota. }\end{array}$ & $\square$ & & \\
\hline 50 & $P$ & 'L'? & $\square$ & $\mathrm{Q}$ & QF \\
\hline 51 & A & Óxido de ferro. & Q & $\mathrm{R}$ & RI \\
\hline 52 & $A^{\prime}$ & Não é 'k'? & $\square$ & $\mathrm{Q}$ & QR \\
\hline
\end{tabular}




\begin{tabular}{|c|c|c|c|c|c|c|c|}
\hline 53 & A & $(\ldots)$ & $\square$ & & & & \\
\hline 54 & $P$ & Monóxido de... dinitrogênio. & & escreve & $\mathrm{AF}$ & INF & \\
\hline 55 & A & Eu disse 'de dinitrogênio'. & ם & & $\mathrm{AF}$ & INF & \\
\hline 56 & $A^{\prime}$ & Ó lá, é ‘mono’. & $\square$ & & $\mathrm{AF}$ & INF & \\
\hline 57 & $P$ & Letra 'c'? Podemos continuar? & $\square$ & & $\begin{array}{l}\mathrm{Q} \\
\mathrm{Q}\end{array}$ & $\begin{array}{l}\mathrm{QF} \\
\mathrm{QC}\end{array}$ & \\
\hline 58 & $A$ & Heptóxido! (...) & $\square$ & & $\mathrm{R}$ & $\mathrm{RI}$ & \\
\hline 59 & $A^{\prime}$ & $\begin{array}{l}\text { (...) a gente não sabe falar. Por } \\
\text { que não pode falar 'sete'? }\end{array}$ & $\square$ & & $\begin{array}{l}\mathrm{AF} \\
\mathrm{Q}\end{array}$ & INF & QA \\
\hline 60 & $\mathrm{P}$ & (...) Dúvida? & $\square$ & & Q & $\mathrm{QC}$ & \\
\hline 61 & A & Duvidar por quê? Sabão é Ipê! & D & & & & \\
\hline 62 & $P$ & 'D'. $\mathrm{SO}_{3}$ ? & $\square$ & & $\mathrm{Q}$ & QF & \\
\hline 63 & $A$ & Trióxido de enxofre. & $\square$ & & $\mathrm{R}$ & RI & \\
\hline 64 & $P$ & David, tudo bem aí? David?! & $\square$ & $\begin{array}{l}\text { Chama a } \\
\text { atenção }\end{array}$ & $\mathrm{O}$ & & \\
\hline 65 & $A$ & $(\ldots)$ & $\square$ & & & & \\
\hline 66 & $P$ & $\begin{array}{l}\text { (...) } \mathrm{P}_{2} \mathrm{O}_{5} \text {, a gente já tinha visto } \\
\text { no exemplo. Então, fica: } \\
\text { pentóxido de... }\end{array}$ & $\square$ & Completem & $\begin{array}{l}\mathrm{AF} \\
\mathrm{Q}\end{array}$ & $\begin{array}{l}\text { INF } \\
\mathrm{CP}\end{array}$ & \\
\hline 67 & $A$ & Difósforo. & $\square$ & & $\mathrm{R}$ & $\mathrm{RI}$ & \\
\hline 68 & $\mathrm{P}$ & 'F'. $\mathrm{CO}_{2}$ ? & $\square$ & & $\mathrm{Q}$ & QF & \\
\hline 69 & $A$ & Dióxido. & $\square$ & & $\mathrm{R}$ & $\mathrm{RI}$ & \\
\hline 70 & $P$ & Dióxido... de... & & $\begin{array}{l}\text { - Escreve } \\
\text { - completem }\end{array}$ & $\mathrm{Q}$ & $\mathrm{CP}$ & \\
\hline 71 & $A$ & Carbono. & $\square$ & & $\mathrm{R}$ & $\mathrm{RI}$ & \\
\hline 72 & $P$ & Carbono. 'G'? & & repete & $\begin{array}{c}\text { REP } \\
\mathrm{Q}\end{array}$ & QF & \\
\hline 73 & $A$ & Monóxido de monocarbono. & $\square$ & & $\mathrm{R}$ & $\mathrm{RI}$ & \\
\hline 74 & $P$ & E 'h'? & $\square$ & & $\mathrm{Q}$ & QF & \\
\hline 75 & $A$ & Trióxido de diferro. & $\square$ & & $\mathrm{R}$ & $\mathrm{RI}$ & \\
\hline 76 & $A^{\prime}$ & Não é ‘di' é ‘de’. & $\square$ & & $\begin{array}{l}\text { FB } \\
\text { AF }\end{array}$ & $\begin{array}{l}\text { DIS } \\
\text { INF }\end{array}$ & \\
\hline 77 & $A$ & 'De diferro' & $\square$ & & $\mathrm{AF}$ & INF & \\
\hline 78 & $P$ & Pessoal, dúvidas aqui? & a & & $\mathrm{Q}$ & QC & \\
\hline 79 & $A$ & Não. & & todos & $\mathrm{R}$ & RI & \\
\hline 80 & $P$ & Nenhuma? & $\square$ & & $\mathrm{Q}$ & QC & \\
\hline 81 & $A$ & Não. & & & $\mathrm{R}$ & RI & \\
\hline
\end{tabular}


Pode-se perceber que nesse episódio há novamente uma queda no nível cognitivo das interações. Embora tenha havido uma grande quantidade de falas por parte dos alunos, essas interações foram de baixo valor cognitivo, conforme mostra a tabela a seguir.

Tabela 18: Distribuição das interações Verbais e Cognitivas em E4A2PA

\begin{tabular}{|c|c|c|c|c|c|}
\hline \multirow{2}{*}{\multicolumn{2}{|c|}{ Interações Verbais }} & \multicolumn{4}{|c|}{ Interações Cognitivas } \\
\hline & & \multicolumn{2}{|c|}{ Ordem Baixa } & \multicolumn{2}{|c|}{ Ordem Alta } \\
\hline Categoria & $N^{\circ}$ de Ocorrências & CAT. & $N^{\circ}$ DE OC. & CAT. & $\mathrm{N}^{\circ}$ DE OC. \\
\hline $\mathrm{Q}$ & 29 & $\mathrm{RI}$ & 22 & $\mathrm{QA}$ & 1 \\
\hline $\mathrm{R}$ & 22 & QF & 18 & & \\
\hline AF & 16 & INF & 14 & & \\
\hline REP & 5 & DIS & 3 & & \\
\hline FB & 3 & QR & 3 & & \\
\hline $\mathrm{O}$ & 3 & $\mathrm{QC}$ & 3 & & \\
\hline \multirow[t]{2}{*}{$\mathrm{C}$} & 2 & $\mathrm{CP}$ & 3 & & \\
\hline & & REF & 2 & & \\
\hline Total & 80 & total & 68 & total & 1 \\
\hline
\end{tabular}

Essa queda no nível cognitivo reforça a hipótese levantada, quando da análise dos dois primeiros episódios dessa aula, de que o baixo nível cognitivo das interações estaria relacionado ao ensino do tópico "nomenclatura dos óxidos", que aqui é retomado. A professora quer aqui que os alunos pratiquem a aplicação das regras de nomenclatura a fim de aprender a dar nome aos óxidos e, de maneira esperada, há um baixo nível cognitivo nas interações que são geradas.

\section{Análise da Aula 2 da Professora A}

Diferentemente da primeira aula da professora A, essa foi preponderantemente voltada à exploração do conceito químico de óxido e à nomenclatura e formulação desses. Abandonou-se, neste caso, o enfoque dado à abordagem CTSA que havia sido usada na aula anterior. A aula foi conduzida em função de uma atividade de nomenclatura e formulação de óxidos e os diálogos foram constituídos basicamente como leituras, questões e respostas dessa atividade.

Já no aspecto da interatividade, as duas aulas foram muito semelhantes, como mostra a tabela a seguir. 
Tabela 19: Avaliação da Interatividade em A2PA em termos da distribuição das falas entre professore e alunos e das interações verbais.

\begin{tabular}{|c|c|c|c|c|c|c|c|}
\hline 1 & 2 & 3 & 4 & 5 & 6 & 7 & 8 \\
\hline $\begin{array}{l}\frac{0}{7} \\
\frac{0}{0} \\
\frac{.0}{2} \\
\text { 문 }\end{array}$ & 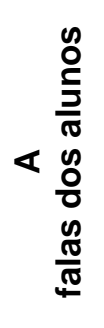 & 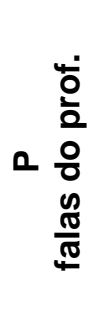 & 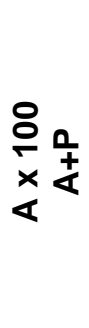 & $\begin{array}{l}\frac{r}{ \pm} \\
\text { O }\end{array}$ & 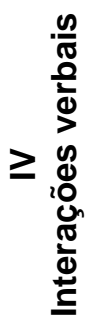 & 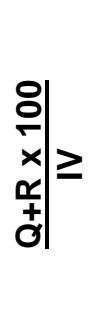 & 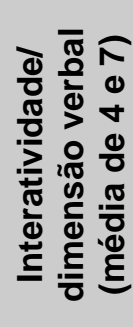 \\
\hline E1A2PA & 24 & 26 & 48 & 41 & 68 & 60 & 54 \\
\hline E2A2PA & 18 & 12 & 60 & 25 & 35 & 71 & 66 \\
\hline E3A2PA & 27 & 22 & 55 & 38 & 61 & 62 & 59 \\
\hline E4A2PA & 49 & 32 & 60 & 51 & 80 & 64 & 62 \\
\hline
\end{tabular}

Percebe-se que os alunos continuam falando por diversas vezes ao longo da aula e que a professora e os alunos travam um diálogo basicamente pautado em questões e respostas. É preciso salientar novamente que as questões quase sempre partem da professora para os alunos, com raras exceções ocorrem questões dos alunos para a professora e nunca entre os próprios alunos.

São muitas as considerações que poderiam ser feitas do ponto de vista das interações sociais com relação a essa postura da professora, mas essa análise da dimensão social das interações não é um dos objetivos deste trabalho de investigação e será deixado de lado nesse momento.

Do ponto de vista da análise da dimensão cognitiva essa aula se torna interessante quando observamos o que ocorreu no terceiro episódio. Embora a aula como um todo tenha seu foco voltado para a discussão de conceitos científicos, no terceiro episódio o foco da discussão foi posto sobre as causas e os efeitos dos poluentes (óxidos) na atmosfera. Essa mudança, mesmo que sutil e momentânea, pôde ser 'captada' pelo instrumento de análise e mostrou uma pequena, mas significativa, mudança no nível cognitivo, como pode ser observada na tabela a seguir. 
Tabela 20: Avaliação do Nível Cognitivo em A2PA em função das interações cognitivas de alta e baixa ordem e em função das questões e respostas de alta e baixa cognitiva.

\begin{tabular}{|c|c|c|c|c|c|c|}
\hline 1 & 2 & 3 & 4 & 5 & 6 & 7 \\
\hline 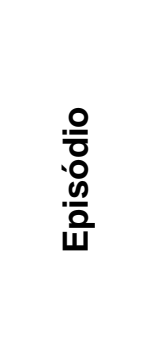 & ع & 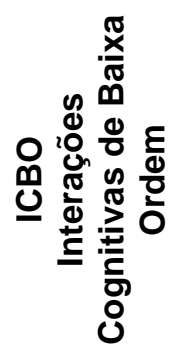 & 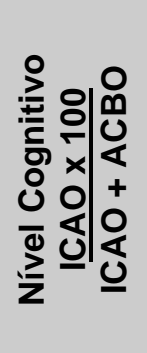 & 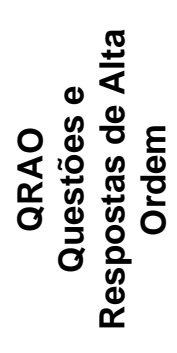 & 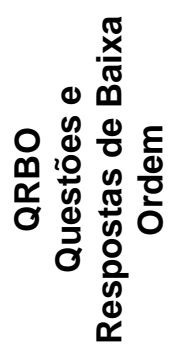 & 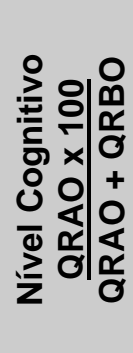 \\
\hline E1A1PA & 1 & 59 & 2 & 1 & 40 & 2 \\
\hline E2A1PA & 1 & 30 & 3 & 1 & 25 & 4 \\
\hline E3A1PA & 6 & 48 & 11 & 6 & 34 & 15 \\
\hline E4A1PA & 1 & 68 & 1 & 1 & 49 & 2 \\
\hline
\end{tabular}

Pode-se considerar, a partir destes dados, que a contextualização dos conteúdos científicos estaria então relacionada a uma melhora no nível cognitivo das interações.

A aula 2 da professora A pode ser caracterizada novamente como interativa de baixa ordem cognitiva, conforme mostra o gráfico a seguir

Gráfico 2: Caracterização da aula 2 da professora A: Aula Interativa de Baixa Ordem Cognitiva

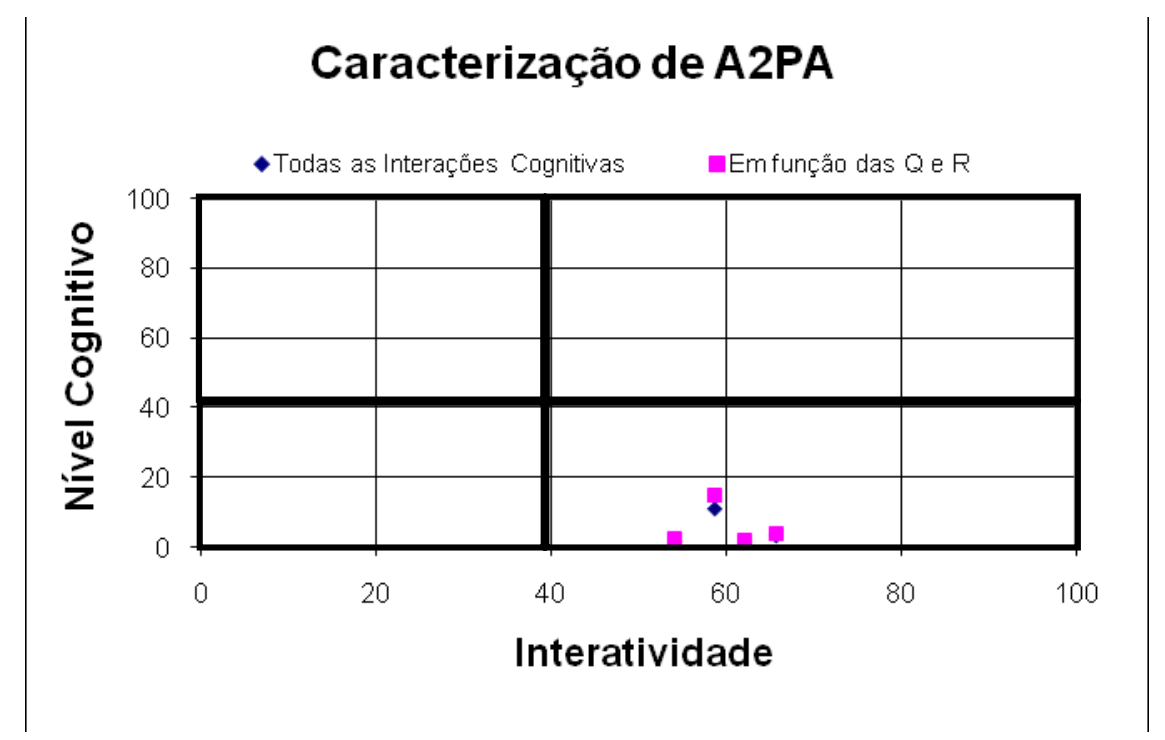

Pode-se perceber nesse gráfico a queda no nível cognitivo, em comparação com a aula 1, comentado anteriormente e a permanência da alta interatividade. 


\section{2 - Aula da Professora B}

Foram gravadas duas aulas da professora B numa turma do $3^{\circ}$ ano do Ensino Médio, no período diurno. A escola está localizada num bairro da periferia da cidade de Carapicuíba/SP. O prédio da escola está razoavelmente conservado e limpo. A turma era formada por alunos com idades entre 16 e 18 anos e muitos deles usavam o uniforme da escola. A sala de aula era desorganizada e as carteiras estavam dispostas em duplas e espalhadas pela sala. Segundo a professora e de acordo com as observações feitas nos dias das coletas de dados, essa turma não apresenta problemas de indisciplina, sendo considerada uma das melhores turmas do período.

$\mathrm{Na}$ primeira aula a discussão girou em torno de dois experimentos demonstrativos sobre condutibilidade elétrica de soluções e reações de oxirredução. Apenas em alguns momentos ocorrem inserções rápidas de temas ligados ao cotidiano, tais como oxidação de um portão de ferro ou o funcionamento de uma pilha comum. A segunda aula foi totalmente dedicada à resolução de questões que buscavam exercitar a capacidade de identificar as espécies químicas que sofreram redução e oxidação e quais seriam, nesses casos, os agentes redutores e oxidantes. Essa aula não será analisada neste trabalho, pois não apresentou nenhum momento de contextualização.

\section{Episódio 1 da aula 1 da professora B (E1A1PB)}

\begin{tabular}{|l|c|l|c|c|c|c|}
\hline \multicolumn{7}{|c|}{ E1A1PB: Experiência sobre condutibilidade elétrica de soluções } \\
\hline Turno & $\begin{array}{c}\text { Quem } \\
\text { fala? }\end{array}$ & Descrição detalhada das falas & $\begin{array}{c}\text { Observações } \\
\text { contexto }\end{array}$ & $\begin{array}{c}\text { Interação } \\
\text { verbal }\end{array}$ & \multicolumn{2}{|c|}{$\begin{array}{c}\text { Interação } \\
\text { cognitiva }\end{array}$} \\
\hline 1 & P & Como se dá? O circuito tá aberto. & & $\begin{array}{c}\text { Q } \\
\text { BF.O. }\end{array}$ & INF & QA \\
\hline 2 & A & $\begin{array}{l}\text { (...) O circuito testa a } \\
\text { condutibilidade da solução de } \\
\text { sulfato de cobre. }\end{array}$ & & R & & RE \\
\hline 3 & $\mathrm{~A}^{\prime}$ & O choque! & risos & AF & INF & \\
\hline
\end{tabular}




\begin{tabular}{|c|c|c|c|c|c|c|}
\hline 4 & $P$ & (...) não segura! Mergulha os dois. & $\begin{array}{l}\text { A profa orienta } \\
\text { um aluno no } \\
\text { uso do } \\
\text { aparelho de } \\
\text { condutibilidade }\end{array}$ & $\mathrm{O}$ & & \\
\hline 5 & $P$ & Acendeu! & & AF & INF & \\
\hline 6 & A & Hee! & & & & \\
\hline 7 & $P$ & Prontinho. & & & & \\
\hline 8 & A & $(\ldots)$ & & & & \\
\hline 9 & $P$ & $\begin{array}{l}\text { Aí vocês perceberam o seguinte: } \\
\text { quando estes dois fios eles } \\
\text { estavam separados, o circuito } \\
\text { está aberto, então, a gente não } \\
\text { vai conseguir... Xii, meninas! Não } \\
\text { deu pra conduzir nada, não deu } \\
\text { pra acender a lâmpada. Por que } \\
\text { quando eu coloquei aqui dentro } \\
\text { desta soluçãozinha eu consegui } \\
\text { acender a lâmpada? }\end{array}$ & $\begin{array}{l}\text { A profa A } \\
\text { mostra o copo } \\
\text { com a solução } \\
\text { enquanto } \\
\text { discute a } \\
\text { atividade }\end{array}$ & $\begin{array}{l}\text { AF } \\
\mathrm{O} \\
\mathrm{Q}\end{array}$ & INF & QA \\
\hline 10 & A & (...) ponte salina. & & $\mathrm{R}$ & $\mathrm{RI}$ & \\
\hline 11 & $P$ & $\begin{array}{l}\text { Então, explica pro resto: o que é } \\
\text { essa ponte salina? }\end{array}$ & & $\begin{array}{l}\mathrm{C} \\
\mathrm{Q}\end{array}$ & QF & \\
\hline 12 & A & $(\ldots)$ & Risos & & & \\
\hline 13 & $P$ & $\begin{array}{l}\text { Ou, sei lá, explica o que você } \\
\text { acha que é essa ponte salina. }\end{array}$ & & Q & & QS \\
\hline 14 & A & (...) liga o circuito aberto. & & $\mathrm{R}$ & & $\mathrm{RE}$ \\
\hline 15 & $\mathrm{P}$ & $\begin{array}{l}\text { Você está fechando o circuito. E } \\
\text { nesta solução tem alguma coisa } \\
\text { que está propiciando que esta } \\
\text { lâmpada acenda. O que será que } \\
\text { tem dentro desta solução que } \\
\text { consegue fazer com que esta } \\
\text { lampadazinha acenda? O que tem } \\
\text { aqui? }\end{array}$ & $\begin{array}{l}\text { A profa dá um } \\
\text { tempo } \\
\text { (segundos) } \\
\text { para que os } \\
\text { alunos pensem } \\
\text { e respondam }\end{array}$ & $\begin{array}{l}\text { AF } \\
\text { AF } \\
Q\end{array}$ & $\begin{array}{l}\text { REF } \\
\text { INF } \\
\text { QF }\end{array}$ & \\
\hline 16 & $P$ & $\begin{array}{l}\text { Por que será que uma lâmpada } \\
\text { acende? Por que será que eu } \\
\text { consigo ligar o rádio? O que tem? }\end{array}$ & & $\begin{array}{l}\mathrm{Q} \\
\mathrm{Q}\end{array}$ & & $\begin{array}{l}\text { QA } \\
\text { QA }\end{array}$ \\
\hline 17 & A & Eletricidade. & & $\mathrm{R}$ & RI & \\
\hline 18 & $P$ & $\begin{array}{l}\text { Eletricidade. Esta eletricidade se } \\
\text { dá a partir do quê? }\end{array}$ & $\begin{array}{l}\text { Repete a fala } \\
\text { dos alunos }\end{array}$ & $\begin{array}{c}\text { REP } \\
\text { Q }\end{array}$ & & QA \\
\hline
\end{tabular}




\begin{tabular}{|c|c|c|c|c|c|c|}
\hline 19 & A & Energia. & & $\mathrm{R}$ & RI & \\
\hline 20 & $P$ & $\begin{array}{l}\text { Energia. A eletricidade é um tipo } \\
\text { de energia. }\end{array}$ & $\begin{array}{l}\text { Repete a fala } \\
\text { dos alunos }\end{array}$ & $\begin{array}{l}\text { REP } \\
\text { AF }\end{array}$ & INF & \\
\hline 21 & A & $(\ldots)$ & & & & \\
\hline 22 & $P$ & Oi? Fala. & & $C$ & & \\
\hline 23 & A & $(\ldots)$ & & & & \\
\hline 24 & $\mathrm{P}$ & $\begin{array}{l}\text { É..., mas eu quero perguntar } \\
\text { assim: Vocês não vão me dar a } \\
\text { energia em si, mas a elétrica, ela } \\
\text { tem a ver com o quê? O que tá } \\
\text { acontecendo? O que eu tenho } \\
\text { aqui que eu consegui fazer esta } \\
\text { lampadazinha acender? }\end{array}$ & & $\begin{array}{c}\mathrm{FB} \\
\mathrm{Q} \\
\mathrm{Q}\end{array}$ & $\begin{array}{l}\text { DIS } \\
\text { QF }\end{array}$ & QA \\
\hline 25 & A & (...) um condutor... & & $\mathrm{R}$ & RI & \\
\hline 26 & $P$ & Um?! & & Q & QC & \\
\hline 27 & A & Um positivo e um negativo. & & $\mathrm{R}$ & $\mathrm{RI}$ & \\
\hline 28 & $P$ & $\begin{array}{l}\text { Exatamente. Você tinha aqui } \\
\text { dentro alguma coisa. }\end{array}$ & & $\begin{array}{l}\text { FB } \\
\text { AF }\end{array}$ & $\begin{array}{l}\text { CON } \\
\text { INF }\end{array}$ & \\
\hline 29 & $\overline{A^{\prime}}$ & Igual à pilha. & & $\mathrm{AF}$ & INF & \\
\hline 30 & $P$ & $\begin{array}{l}\text { Igual a pilha. Mas aqui não seria } \\
\text { igual à pilha que vocês estão } \\
\text { acostumados a ver. Mas na } \\
\text { verdade aqui esta solução está } \\
\text { servindo de um material que } \\
\text { proporciona uma corrente. }\end{array}$ & $\begin{array}{l}\text { Repete a fala } \\
\text { dos alunos }\end{array}$ & $\begin{array}{c}\text { REP } \\
\text { FB } \\
\text { AF }\end{array}$ & $\begin{array}{l}\text { DIS } \\
\text { INF }\end{array}$ & \\
\hline 31 & A & Negativa e uma positiva. & & AF & INF & \\
\hline 32 & $P$ & $\begin{array}{l}\text { Uma corrente elétrica. Então, aqui } \\
\text { dentro eu vou ter...íons! Só que eu } \\
\text { vou deixar pra gente continuar } \\
\text { desta partezinha aqui. Então, a } \\
\text { gente já sabe que dentro dessa } \\
\text { solução eu tenho o cobre... e tem } \\
\text { sulfato. E a água que tá... eles } \\
\text { estão numa solução aquosa. } \\
\text { Certo? }\end{array}$ & & $\begin{array}{l}\mathrm{AF} \\
\mathrm{Q}\end{array}$ & $\begin{array}{l}\text { INF } \\
\mathrm{QC}\end{array}$ & \\
\hline
\end{tabular}

A professora B inicia sua aula sobre o tema eletroquímica realizando uma atividade experimental demonstrativa. Inicialmente ela testa a condutibilidade elétrica de uma solução aquosa de sulfato de cobre. Para isso ela utiliza um 
aparelho simples formado por um conjunto de lâmpadas de diferentes potências. As pontas de teste (pontas de fios desencapados) são mergulhadas na solução que, por conter íons sulfato e cobre II em quantidades suficientes, promovem a condução elétrica e as lâmpadas acendem. Essa atividade, embora seja de simples realização, não é fácil de ser explicada se os estudantes não tiverem o conceito de íons bem formado. Como resultado, as respostas dos estudantes foram mais próximas do senso comum do que de concepções científicas sobre o fenômeno da condução elétrica em solução. Aparentemente o objetivo da professora era que os estudantes chegassem à conclusão de que a condução elétrica responsável pelo acendimento da lâmpada ocorreu por causa da presença dos íons em solução (turno 27 e 28). Entretanto, as idéias dos estudantes se aproximaram mais da concepção alternativa de que "a lâmpada acendeu por causa da presença de uma corrente elétrica positiva e uma negativa".

A admissão da existência de partículas microscópicas carregadas positiva e negativamente e que permitem a passagem de corrente elétrica no líquido que as contenha não é nada intuitiva. Assim, dificilmente essa idéia pode ser construída apenas num momento de reflexão sobre as observações de um experimento. Mesmo estudantes que já tenham passado pelo ensino formal do conceito de íons como os estudantes da professora B - apresentam dificuldades em aplicar esse conhecimento na explicação de um fenômeno de condução elétrica em soluções. Percebendo isso nas falas dos estudantes, a professora propõe a existência dos íons na solução de sulfato de cobre e que seriam os responsáveis pela condutibilidade elétrica dela (turno 32).

Pouca referência foi feita a elementos do cotidiano nas falas construídas nesse episódio. O único momento em que algo próximo à vivência dos estudantes veio à tona ocorreu nas falas 15 e 16. Inicialmente a professora busca dos estudantes uma explicação para o fato de a lâmpada ter acendido a partir das observações da demonstração experimental feita em sala de aula. Como ela não obteve resposta por parte dos estudantes, parece recorrer na fala 16 a um elemento que Ihes parecesse familiar, ligar um rádio, para motivar a participação ou facilitar a resposta a sua questão (fala 16). A questão centrada na observação experimental não foi respondida, mas a questão equivalente centrada num elemento do cotidiano foi, mesmo que a resposta não fosse a esperada. 
Pode-se perceber nesse episódio um número significativo de interações cognitivas de ordem alta (questões abertas e respostas explicativas). Contudo essas interações partiram basicamente da professora. Além disso, mesmo diante das questões abertas propostas pela professora, as respostas dos estudantes foram em sua maioria frases curtas e pouco elaboradas, classificadas como de baixa ordem cognitiva.

Tabela 21: Distribuição das interações Verbais e Cognitivas em E1A1PB

\begin{tabular}{|c|c|c|c|c|c|}
\hline \multicolumn{2}{|c|}{ Interações Verbais } & \multicolumn{4}{c|}{ Interações Cognitivas } \\
\cline { 3 - 6 } & \multicolumn{2}{|c|}{ Ordem Baixa } & \multicolumn{2}{c|}{ Ordem Alta } \\
\hline Categoria & $N^{\circ}$ de Ocorrências & CAT. & $N^{\circ}$ DE OC. & CAT. & $N^{\circ}$ DE OC. \\
\hline Q & 12 & INF & 11 & QA & 7 \\
\hline AF & 11 & RI & 5 & RE & 2 \\
\hline R & 7 & QF & 3 & & \\
\hline REP & 3 & DIS & 2 & & \\
\hline FB & 3 & QC & 2 & & \\
\hline O & 2 & QS & 1 & & \\
\hline C & 2 & REF & 1 & & \\
\hline Total & & CON & 1 & & \\
\hline
\end{tabular}

\section{Episódio 2 da aula 1 da professora B (E2A1PB)}

\begin{tabular}{|c|c|c|c|c|c|c|}
\hline \multicolumn{7}{|c|}{ E2A1PB: Experiência sobre oxirredução } \\
\hline \multirow[t]{2}{*}{ Turno } & \multirow{2}{*}{$\begin{array}{l}\text { Quem } \\
\text { fala? }\end{array}$} & \multirow[t]{2}{*}{ Descrição detalhada das falas } & \multirow{2}{*}{$\begin{array}{c}\text { Observações } \\
\text { Contexto }\end{array}$} & \multirow{2}{*}{$\begin{array}{c}\text { Interação } \\
\text { Verbal }\end{array}$} & \multicolumn{2}{|c|}{$\begin{array}{l}\text { Interação } \\
\text { Cognitiva } \\
\end{array}$} \\
\hline & & & & & B.O. & A.O. \\
\hline 1 & $P$ & $\begin{array}{l}\text { Agora vamos ver se aquilo que } \\
\text { vocês falaram pra mim... Eu to } \\
\text { pegando um clipe comum de } \\
\text { caderno. Eu quero fazer o } \\
\text { seguinte: se eu quisesse banhar } \\
\text { este clipe... eu quisesse que ele } \\
\text { virasse igual uma coisinha que } \\
\text { vocês tem aí... igual uma bijuteria. } \\
\text { Vocês podem derreter o metal pra } \\
\text { banhar. Não é isso que vocês } \\
\text { disseram pra mim? Eu vou } \\
\text { colocar aqui dentro; vou fazer um } \\
\text { teste. }\end{array}$ & $\begin{array}{l}\text { A professora } \\
\text { propõe uma } \\
\text { nova } \\
\text { demonstração e } \\
\text { a apresenta para } \\
\text { a turma }\end{array}$ & $\begin{array}{l}\text { AF } \\
Q \\
\text { AF }\end{array}$ & $\begin{array}{l}\text { QC } \\
\text { INF }\end{array}$ & HIP \\
\hline 2 & $A$ & Êita! & & & & \\
\hline
\end{tabular}




\begin{tabular}{|c|c|c|c|c|c|c|}
\hline 3 & $\mathrm{P}$ & Dá pra ver? & & Q & QC & \\
\hline 4 & $A^{\prime}$ & Êita! & & & & \\
\hline 5 & $\mathrm{P}$ & $\begin{array}{l}\text { Tem uma coisinha pra pegar? Ah! } \\
\text { A tesoura! Ou tem outra coisa... } \\
\text { um lápis. }\end{array}$ & & $\mathrm{O}$ & & \\
\hline 6 & A & Coloca o dedo aí! & & $\mathrm{O}$ & & \\
\hline 7 & $A^{\prime}$ & Por que não pode por o dedo? & & $\mathrm{Q}$ & & QA \\
\hline 8 & $\mathrm{P}$ & $(\ldots)$ & $\begin{array}{l}\text { A profa retira o } \\
\text { clipe da solução } \\
\text { de } \mathrm{CuSO}_{4}\end{array}$ & & & \\
\hline 9 & $\mathrm{P}$ & Ó. & $\begin{array}{l}\text { Mostra o clipe } \\
\text { para turma }\end{array}$ & & & \\
\hline 10 & A & Credo! & & & & \\
\hline 11 & $\mathrm{P}$ & $\begin{array}{l}\text { Ele tá assim: ele escureceu. Aí } \\
\text { qual seria a explicação; por que } \\
\text { ele escureceu? }\end{array}$ & & $\begin{array}{l}\mathrm{AF} \\
\mathrm{Q}\end{array}$ & INF & QA \\
\hline 12 & A & Tirou o brilho. & & $\mathrm{R}$ & $\mathrm{RD}$ & \\
\hline 13 & $P$ & $\begin{array}{l}\text { Tirou o brilho. Quer dizer: saiu } \\
\text { alguma coisa. Você acha que saiu } \\
\text { alguma coisa do clipe e foi pra } \\
\text { dentro da solução. Alguém tem } \\
\text { uma outra sugestão? }\end{array}$ & $\begin{array}{l}\text { Repete a fala do } \\
\text { aluno }\end{array}$ & $\begin{array}{l}\text { REP } \\
\text { AF } \\
\text { C }\end{array}$ & PAR & \\
\hline 14 & A & $(\ldots)$ & & & & \\
\hline 15 & $P$ & $\begin{array}{l}\text { Aí sim... como a (...) falou, mudou } \\
\text { alguma coisa. Será que ele } \\
\text { enferrujou como alguém falou? }\end{array}$ & & $\begin{array}{l}\mathrm{FB} \\
\mathrm{Q}\end{array}$ & $\begin{array}{l}\text { CON } \\
\text { QF }\end{array}$ & \\
\hline 16 & A & Ele oxidou. & & $\mathrm{R}$ & $\mathrm{RI}$ & \\
\hline 17 & $\mathrm{P}$ & Ele oxidou. & & REP & & \\
\hline 18 & $P$ & $\begin{array}{l}\text { A mesma coisa aconteceria com... } \\
\text { sei lá.... um portão reagindo, } \\
\text { reagindo com o oxigênio. Foi o } \\
\text { que aconteceu com este clipe } \\
\text { reagindo com a solução. Mas } \\
\text { reagindo quem? }\end{array}$ & & $\begin{array}{l}\text { AF } \\
Q\end{array}$ & $\begin{array}{l}\text { EX } \\
\text { QF }\end{array}$ & \\
\hline 19 & $\mathrm{P}$ & $\begin{array}{l}\text { E por último... bombril. Bombril } \\
\text { normal. Bom, vou colocar esse } \\
\text { bombril. O que tem no bombril? }\end{array}$ & $\begin{array}{l}\text { Interrupção } \\
\text { administrativa } \\
\text { pelo inspetor de } \\
\text { alunos. }\end{array}$ & $\begin{array}{l}\mathrm{O} \\
\mathrm{Q}\end{array}$ & QF & \\
\hline 20 & A & Aço. & & $\mathrm{R}$ & $\mathrm{RI}$ & \\
\hline 21 & $\mathrm{P}$ & Aço. E no aço tem... & Repete a fala de & REP & $\mathrm{CP}$ & \\
\hline
\end{tabular}




\begin{tabular}{|c|c|c|c|c|c|c|}
\hline & & & $\begin{array}{l}\text { um aluno e } \\
\text { convida a } \\
\text { completar a } \\
\text { frase. } \\
\text { Põe uma bolinha } \\
\text { de bombril na } \\
\text { solução de } \\
\text { CuSO }_{4} \text { e passa } \\
\text { pela sala }\end{array}$ & Q & & \\
\hline 22 & $\mathrm{P}$ & $\begin{array}{l}\text { Bom, vai mexendo aqui e vai } \\
\text { passando pro resto da sala ver. }\end{array}$ & & $\mathrm{O}$ & & \\
\hline 23 & $A$ & Vixe, vai demorar um monte. & & AF & INF & \\
\hline 24 & $\mathrm{P}$ & $\begin{array}{l}\text { Só dá uma mexidinha e vai } \\
\text { passando pro resto da sala ver. }\end{array}$ & & $\mathrm{O}$ & & \\
\hline 25 & $A$ & Tá fazendo sopa. & Risos & & & \\
\hline 26 & $\mathrm{P}$ & $\begin{array}{l}\text { Vocês viram a cor do bombril, } \\
\text { lógico, né? Que cor que ele ficou } \\
\text { aqui? Por que ele ficou... da cor } \\
\text { de quê? }\end{array}$ & $\begin{array}{l}\text { Mostra a bolinha } \\
\text { de bombril para } \\
\text { a turma }\end{array}$ & $\begin{array}{l}\mathrm{Q} \\
\mathrm{Q} \\
\mathrm{Q}\end{array}$ & $\begin{array}{l}\text { QC } \\
\text { QF }\end{array}$ & QA \\
\hline 27 & $A$ & (...) da cor do cabelo dela. & & $\mathrm{R}$ & $\mathrm{RD}$ & \\
\hline 28 & $\mathrm{P}$ & $\begin{array}{l}\text { Mas da cor de que elemento? O } \\
\text { que vocês falaram? }\end{array}$ & & Q & QF & \\
\hline 29 & $A$ & Ferrugem. & & $\mathrm{R}$ & $\mathrm{RI}$ & \\
\hline 30 & $\mathrm{P}$ & Ferrugem. Da cor do cobre. & $\begin{array}{l}\text { Repete a fala do } \\
\text { aluno }\end{array}$ & $\begin{array}{l}\text { REP } \\
\text { AF }\end{array}$ & INF & \\
\hline 31 & $P$ & $\begin{array}{l}\text { Eu vou por mais. Vou por todo o } \\
\text { bombril que eu tinha. }\end{array}$ & & $\mathrm{O}$ & & \\
\hline 32 & $A$ & O professora! (...) & & & & \\
\hline 33 & $P$ & $\begin{array}{l}\text { Tá acontecendo mais alguma } \\
\text { outra coisa, além disso? }\end{array}$ & & Q & & QA \\
\hline 34 & $A$ & (...) solução. & & & & \\
\hline 35 & $\mathrm{P}$ & $\begin{array}{l}\text { Mas ele ainda tem o quê? Tá } \\
\text { mudando alguma coisa além da } \\
\text { cor do bombril? }\end{array}$ & & Q & QF & \\
\hline 36 & $A$ & $(\ldots)$ & & & & \\
\hline 37 & $A^{\prime}$ & O bombril ta absorvendo a (...) & & $\mathrm{R}$ & & $\mathrm{RE}$ \\
\hline 38 & $\mathrm{P}$ & O bombril ta... Xii! & Pede silêncio & $\begin{array}{l}\mathrm{Q} \\
\mathrm{O}\end{array}$ & $\mathrm{CP}$ & \\
\hline 39 & A & Tá... absorvendo a... & & & & \\
\hline 40 & $\mathrm{P}$ & Xii! Oh, meninos! & & $\mathrm{O}$ & & \\
\hline
\end{tabular}




\begin{tabular}{|c|c|c|c|c|c|c|}
\hline 41 & $A^{\prime}$ & $\begin{array}{l}\text { Tá absorvendo a química que tem } \\
\text { aí. }\end{array}$ & & $\mathrm{R}$ & & RE \\
\hline 42 & $\mathrm{P}$ & Que química? & & Q & QF & \\
\hline 43 & $A^{\prime}$ & Não sei (...). & & $\mathrm{R}$ & RI & \\
\hline 44 & $P$ & Tá mudando mais alguma coisa? & & Q & QF & \\
\hline 45 & $A$ & A solução, a solução! & & $\mathrm{R}$ & RI & \\
\hline 46 & $\mathrm{P}$ & Aqui ta começando a... & & Q & QC & \\
\hline 47 & A & ... ficar transparente & $\begin{array}{l}\text { Completou a } \\
\text { frase da } \\
\text { professora }\end{array}$ & $\mathrm{R}$ & $\mathrm{RD}$ & \\
\hline 48 & $\mathrm{P}$ & $\begin{array}{l}\text { (...) a soltar... não ficando mais } \\
\text { aquela bolinha... e a cor da } \\
\text { solução... }\end{array}$ & $\begin{array}{l}\text { Solicita que } \\
\text { completem a } \\
\text { frase }\end{array}$ & $\begin{array}{l}\mathrm{AF} \\
\mathrm{Q}\end{array}$ & $\begin{array}{l}\text { INF } \\
\text { CP }\end{array}$ & \\
\hline 49 & A & $(\ldots)$ & & & & \\
\hline 50 & $\mathrm{P}$ & $\begin{array}{l}\text { Tá desaparecendo. Alguém } \\
\text { consegue me explicar, mais ou } \\
\text { menos, o que pode estar } \\
\text { acontecendo aqui? Lembrando o } \\
\text { que eu fiz. }\end{array}$ & & $\begin{array}{l}\mathrm{AF} \\
\mathrm{Q}\end{array}$ & INF & QA \\
\hline 51 & A & $(\ldots)$ & & & & \\
\hline 52 & $P$ & Oi? Vocês viram isso no cursinho. & $\begin{array}{l}\text { A turma é de } 3^{\circ} \\
\text { ano e alguns } \\
\text { alunos fazem } \\
\text { curso } \\
\text { preparatório } \\
\text { para o } \\
\text { vestibular } \\
\text { durante a tarde. }\end{array}$ & & & \\
\hline
\end{tabular}

Nesse episódio há a realização de uma segunda parte experimental, novamente na forma de demonstração. Dessa vez a professora utiliza materiais comuns aos estudantes (clipe metálico e palha de aço), além do sulfato de cobre, reagente não tão presente no cotidiano dos estudantes. É provável que a inserção desses materiais do cotidiano na atividade experimental tenha ocorrido com 0 objetivo de aproximar o conteúdo químico dos conhecimentos extra-escolares dos estudantes, ou seja, trata-se de uma forma de contextualização do conhecimento científico aplicado à experimentação. De modo semelhante à contextualização, essa inserção de materiais do cotidiano na atividade experimental provavelmente 
propunha-se a despertar o interesse dos estudantes pelo conteúdo científico que se buscava ensinar, facilitar sua aprendizagem e mostrar a presença da ciência no cotidiano.

Observa-se que após a demonstração da interação entre o clipe metálico e a solução de sulfato de cobre, a questão feita pela professora no turno 11, "Aí qual seria a explicação; por que ele escureceu?", não obteve resposta satisfatória num primeiro momento, mas ela foi induzida pela professora entre os turnos 12 e 18.

A interação entre a palha de aço e a solução de sulfato de cobre é explorada a partir da descrição das observações sobre o fenômeno e culmina com o questionamento sobre uma possível explicação para o fenômeno (turno 50).

Em nenhum dos caminhos escolhidos pela professora os estudantes conseguiram atingir as respostas desejadas para as questões explicativas propostas; apenas respostas parciais e pouco elaboradas foram dadas nas falas 16 e 41, por exemplo.

Outro ponto a ser considerado, mas não pode ser afirmado, é que as respostas que mais se aproximaram do esperado podem ter partido de alguns estudantes que já haviam estudado esse assunto em curso pré-vestibular, conforme falas 52.

Tabela 22: Distribuição das interações Verbais e Cognitivas em E2A1PB

\begin{tabular}{|c|c|c|c|c|c|}
\hline \multirow{2}{*}{\multicolumn{2}{|c|}{ Interações Verbais }} & \multicolumn{4}{|c|}{ Interações Cognitivas } \\
\hline & & \multicolumn{2}{|c|}{ Ordem Baixa } & \multicolumn{2}{|c|}{ Ordem Alta } \\
\hline Categoria & $\mathrm{N}^{\circ}$ de Ocorrências & CAT. & $\mathrm{N}^{\circ}$ DE OC. & CAT. & $\mathrm{N}^{\circ}$ DE OC. \\
\hline $\mathrm{Q}$ & 20 & QF & 8 & QA & 5 \\
\hline $\mathrm{R}$ & 10 & INF & 6 & $\mathrm{RE}$ & 2 \\
\hline $\mathrm{AF}$ & 9 & $\mathrm{RI}$ & 5 & HIP & 1 \\
\hline $\mathrm{O}$ & 8 & $\mathrm{QC}$ & 4 & & \\
\hline REP & 4 & $\mathrm{RD}$ & 3 & & \\
\hline $\mathrm{C}$ & 1 & $\mathrm{CP}$ & 3 & & \\
\hline \multirow[t]{3}{*}{$\mathrm{FB}$} & 1 & PAR & 1 & & \\
\hline & & CON & 1 & & \\
\hline & & EX & 1 & & \\
\hline Total & 53 & Total & 32 & total & 8 \\
\hline
\end{tabular}

Episódio 3 da aula 1 da professora B (E3A1PB)

E3A1PB: Representação da equação química

\begin{tabular}{|c|c|c|c|c|c|c|}
\hline Turno & $\begin{array}{c}\text { Quem } \\
\text { fala? }\end{array}$ & Descrição detalhada das falas & $\begin{array}{c}\text { Observações } \\
\text { Contexto }\end{array}$ & $\begin{array}{c}\text { Interação } \\
\text { verbal }\end{array}$ & \multicolumn{2}{|c|}{$\begin{array}{c}\text { Interação } \\
\text { cognitiva }\end{array}$} \\
\cline { 5 - 7 } & & & B.O. & A.O. \\
\hline
\end{tabular}




\begin{tabular}{|c|c|c|c|c|c|c|c|}
\hline 1 & $P$ & $\begin{array}{l}\text { O que eu tinha aqui? Sulfato de } \\
\text { cobre, certo? Lembra quando a } \\
\text { gente fazia ácidos, bases e a } \\
\text { gente tinha que olhar quanto valia } \\
\text { cada um dos elementos e se era } \\
\text { positivo, se era negativo (...) } \\
\text { Vocês lembram qual era a carga } \\
\text { que tinha o cobre? }\end{array}$ & ם & $\begin{array}{l}\text { Questão } \\
\text { retórica }\end{array}$ & $\begin{array}{c}\mathrm{Q} \\
\mathrm{AF} \\
\mathrm{Q} \\
\mathrm{Q}\end{array}$ & $\begin{array}{l}\text { QR } \\
\text { INF } \\
\text { QC } \\
\text { QF }\end{array}$ & \\
\hline 2 & $A$ & Positivo. & a & & $\mathrm{R}$ & $\mathrm{RI}$ & \\
\hline 3 & $P$ & $\begin{array}{l}\text { Positivo. Se ele é positivo, } \\
\text { obviamente a parte do sulfato é... }\end{array}$ & & completar & $\begin{array}{c}\text { REP } \\
\mathrm{Q}\end{array}$ & $\mathrm{CP}$ & \\
\hline 4 & A & Negativa. & & $\begin{array}{l}\text { Todos } \\
\text { respondem }\end{array}$ & $\mathrm{R}$ & $\mathrm{RI}$ & \\
\hline 5 & $P$ & $\begin{array}{l}\text { Negativo. Então, essa } \\
\text { composição que eu tinha no } \\
\text { copinho... e no ferro, no bombril } \\
\text { eu tinha... o ferro. Então, aqui eu } \\
\text { tinha o ferro. O ferro tá sozinho. } \\
\text { Ele tá aqui em forma de metal, } \\
\text { não tava? Ele não tava nem em } \\
\text { solução, nem num sal. Se ele tava } \\
\text { em forma de metal... Paulo!... eu } \\
\text { falo que a valência dele ou a } \\
\text { carga dele é zero; é ferro zero. Se } \\
\text { acontece uma reação... aí } \\
\text { acontece alguma coisa. O que } \\
\text { aconteceu aqui neste caso? Eu } \\
\text { coloquei o bombril na solução. } \\
\text { Quais foram as evidências que } \\
\text { vocês tiveram? }\end{array}$ & a & & $\begin{array}{c}\text { REP } \\
\text { AF } \\
\text { Q } \\
\text { AF } \\
\text { O } \\
\text { AF } \\
\text { Q } \\
\text { Q }\end{array}$ & $\begin{array}{l}\text { INF } \\
\text { QR } \\
\text { INF } \\
\text { INF }\end{array}$ & $\begin{array}{l}\text { QA } \\
\text { QA }\end{array}$ \\
\hline 6 & A & O ferro se dissolveu. & $\square$ & & $\mathrm{R}$ & $\mathrm{RI}$ & \\
\hline 7 & $A^{\prime}$ & O cobre dissolve o ferro... (...) & a & & $\mathrm{R}$ & & $\mathrm{RE}$ \\
\hline 8 & A & $\begin{array}{l}\text { É como se eles tivessem se } \\
\text { misturado. }\end{array}$ & a & & $\mathrm{R}$ & & $\mathrm{RE}$ \\
\hline 9 & $\mathrm{P}$ & $\begin{array}{l}\text { Como se tivesse se misturado. } \mathrm{O} \\
\text { que mais? Aconteceu mais } \\
\text { alguma coisa? (...) }\end{array}$ & a & & $\begin{array}{c}\text { REP } \\
\mathrm{Q}\end{array}$ & & QA \\
\hline 10 & $\mathrm{P}$ & Só mudou a cor do bombril? & D & & $\mathrm{Q}$ & QF & \\
\hline 11 & $A$ & Não. & ב & & $\mathrm{R}$ & $\mathrm{RI}$ & \\
\hline 12 & $\mathrm{P}$ & O que mais? Então, mudou as & ב & & REP & & SIN \\
\hline
\end{tabular}




\begin{tabular}{|c|c|c|c|c|c|c|}
\hline & & $\begin{array}{l}\text { duas coisas que eu tinha. Os dois } \\
\text { reagentes que eu tinha sofreram } \\
\text { uma transformação. Tanto o } \\
\text { reagente que eu tinha, a solução, } \\
\text { quanto o metal. }\end{array}$ & & AF & & \\
\hline 13 & $\mathrm{P}$ & $\begin{array}{l}\text { Tentem ver pra mim: como seriam } \\
\text { as duas cargas que eu tenho } \\
\text { aqui? Tanto do cobre quanto do } \\
\text { sulfato. }\end{array}$ & a & $\mathrm{Q}$ & QF & \\
\hline 14 & A & $(\ldots)$ & 口 & & & \\
\hline 15 & $\mathrm{P}$ & Oi? & a & & & \\
\hline 16 & A & Tem que dar zero. & 口 & $\mathrm{AF}$ & INF & \\
\hline 17 & $P$ & $\begin{array}{l}\text { Tem que dar zero também. } \\
\text { Lembra que eu falo assim: você } \\
\text { nunca pode ter cargas a mais } \\
\text { positiva nem carga a mais } \\
\text { negativa. Tem que tá sempre } \\
\text { dando zero. Qual que é o valor } \\
\text { aqui? No caso seria mais fácil } \\
\text { você olhar pelo sulfato, que ele... }\end{array}$ & a completem & $\begin{array}{c}\mathrm{REP} \\
\mathrm{AF} \\
\mathrm{Q} \\
\mathrm{AF}\end{array}$ & $\begin{array}{l}\text { INF } \\
\text { QF } \\
\text { INF }\end{array}$ & \\
\hline 18 & A & Dois menos. & a & $\mathrm{R}$ & RI & \\
\hline 19 & $P$ & $\begin{array}{l}\text { Dois menos. Se você falou que } \\
\text { ele tem que dar zero, o cobre tem } \\
\text { que ser... }\end{array}$ & c completem & $\begin{array}{c}\text { REP } \\
\mathrm{Q}\end{array}$ & $\mathrm{CP}$ & \\
\hline 20 & A & Dois mais. & a & $\mathrm{R}$ & $\mathrm{RI}$ & \\
\hline 21 & $P$ & $\begin{array}{l}\text { Dois mais. Alguém sugere pra } \\
\text { mim o que que acontece aqui? Na } \\
\text { verdade você tem os dois metais. } \\
\text { Sempre que você fala em pilha, } \\
\text { você fala em bateria, ou em } \\
\text { reação de oxirredução, você } \\
\text { sempre trabalha com que tipo de } \\
\text { material? Com metal! Você } \\
\text { sempre tá falando de ferro, de } \\
\text { níquel... E fiz o mesmo teste que } \\
\text { eu fiz aqui com o clipe e com o } \\
\text { bombril, eu fiz com o níquel. Eu } \\
\text { peguei uma moedinha e deixei } \\
\text { aqui dentro da solução. Só que } \\
\text { demorou muito mais tempo. }\end{array}$ & a & $\begin{array}{c}\text { REP } \\
\mathrm{Q} \\
\mathrm{AF} \\
\mathrm{Q} \\
\mathrm{AF}\end{array}$ & $\begin{array}{l}\text { INF } \\
\text { QR } \\
\text { INF }\end{array}$ & QA \\
\hline
\end{tabular}




\begin{tabular}{|c|c|c|c|c|c|c|}
\hline 22 & A & $(\ldots)$ & a & & & \\
\hline 23 & $P$ & $\begin{array}{l}\text { Quer tentar? Só que aqui já tem } \\
\text { bastante e eu não tenho onde } \\
\text { descartar. }\end{array}$ & ם & & $\begin{array}{l}\mathrm{C} \\
\mathrm{O}\end{array}$ & \\
\hline 24 & A & $(\ldots)$ & ם & & & \\
\hline 25 & $\mathrm{P}$ & $\begin{array}{l}\text { Tudo bem (...) O mesmo teste que } \\
\text { eu fiz aqui com o clipe e com o } \\
\text { bombril, mas só que demorou um } \\
\text { tempo maior, mas ela também } \\
\text { ficou com aquela corzinha } \\
\text { avermelhada. }\end{array}$ & a & & AF & INF \\
\hline 26 & A & Pode ser este aqui? & & $\begin{array}{l}\text { Uma aluna } \\
\text { mostra um } \\
\text { pequeno } \\
\text { objeto }\end{array}$ & $\mathrm{O}$ & \\
\hline 27 & $\mathrm{P}$ & $\begin{array}{l}\text { Não, depois a gente testa. Agora } \\
\text { não tem nem onde colocar. }\end{array}$ & a & & $\mathrm{O}$ & \\
\hline 28 & A & $(\ldots)$ & D & & & \\
\hline 29 & $\mathrm{P}$ & $\begin{array}{l}\text { Não, a gente não vai jogar isso } \\
\text { aqui assim. Depois eu trago de } \\
\text { novo e a gente faz. Esse eu vou } \\
\text { guardar. }\end{array}$ & a & & $\mathrm{O}$ & \\
\hline 30 & $A$ & Tem que comprar? & D & & 0 & \\
\hline 31 & $P$ & $\begin{array}{l}\text { Quem compra é a escola. Mas } \\
\text { voltando. Sempre que você } \\
\text { trabalha com reações de } \\
\text { oxirredução, que seriam as pilhas, } \\
\text { as baterias... até quem deu uma } \\
\text { olhadinha aí na parte da apostila } \\
\text { já viu isso, sempre envolve metal. } \\
\text { Então, quem que tá interagindo } \\
\text { aqui? Quem que mexeu a cor? } \\
\text { Mexeu na cor da soluçãozinha } \\
\text { azul, que tinha o quê na solução? }\end{array}$ & a & & $\begin{array}{l}\mathrm{O} \\
\mathrm{AF} \\
\mathrm{Q} \\
\mathrm{Q} \\
\mathrm{Q}\end{array}$ & $\begin{array}{l}\text { INF } \\
\text { QF } \\
\text { QF } \\
\text { QF }\end{array}$ \\
\hline 32 & $A$ & Cobre. & ם & & $\mathrm{R}$ & $\mathrm{RI}$ \\
\hline 33 & $P$ & $\begin{array}{l}\text { Cobre. E no ferro que era, sei lá, } \\
\text { prateado, ficou... }\end{array}$ & & completem & $\begin{array}{l}\text { REP } \\
\text { Q }\end{array}$ & $\mathrm{CP}$ \\
\hline 34 & $A$ & $(\ldots)$ & a & & & \\
\hline 35 & $P$ & Ficou que cor? & & $\begin{array}{l}\text { Mostra o } \\
\text { copo com a }\end{array}$ & REP & \\
\hline
\end{tabular}




\begin{tabular}{|c|c|c|c|c|c|c|}
\hline & & & $\begin{array}{l}\text { palha de } \\
\text { aço }\end{array}$ & & & \\
\hline 36 & $A$ & (...) cobre. & a & $\mathrm{R}$ & $\mathrm{RD}$ & \\
\hline 37 & $\mathrm{P}$ & $\begin{array}{l}\text { Cor de cobre. Então quer dizer } \\
\text { que aconteceu o que nestes dois } \\
\text { casos? Quem mexeu? Quem } \\
\text { mudou? Ninguém saiu do lugar? } \\
\text { O que pode ter acontecido? }\end{array}$ & $\square$ & $\begin{array}{c}\text { REP } \\
\mathrm{Q} \\
\mathrm{Q}\end{array}$ & QF & QA \\
\hline 38 & A & Mexeu nos dois. & a & $\mathrm{R}$ & RI & \\
\hline 39 & $\mathrm{P}$ & Mexeu nos dois quem? & ב & $\mathrm{Q}$ & QF & \\
\hline 40 & A & (...) no cobre. & 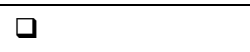 & $\mathrm{R}$ & $\mathrm{RI}$ & \\
\hline 41 & $\mathrm{P}$ & No... no cobre e no... & a completem & $\begin{array}{c}\text { REP } \\
\mathrm{Q}\end{array}$ & $\mathrm{CP}$ & \\
\hline 42 & A & Sulfato. & $\square$ & $\mathrm{R}$ & $\mathrm{RI}$ & \\
\hline 43 & $\mathrm{P}$ & $\begin{array}{l}\text { No cobre e no sulfato. Tá? Então } \\
\text { quer dizer que aqui apareceu uma } \\
\text { separação, você quer dizer? }\end{array}$ & a & $\begin{array}{c}\text { REP } \\
\mathrm{Q} \\
\mathrm{Q}\end{array}$ & $\begin{array}{l}\text { QC } \\
\text { QF }\end{array}$ & \\
\hline 44 & A & $\begin{array}{l}\text { Eu achei que os dois tinham } \\
\text { perdido... }\end{array}$ & $\square$ & $\mathrm{R}$ & RI & \\
\hline 45 & $P$ & Tinham perdido... o quê? & $\square$ & $\mathrm{Q}$ & QF & \\
\hline 46 & A & (...) as cargas. & a & $\mathrm{R}$ & $\mathrm{RI}$ & \\
\hline 47 & $\mathrm{P}$ & As cargas. & $\square$ & REP & & \\
\hline 48 & A & $(\ldots)$ & $\square$ & & & \\
\hline 49 & $P$ & $\begin{array}{l}\text { Bom, você tá indo pelo raciocínio } \\
\text { certo. Vamos pensar assim: } \\
\text { lembra quando a gente fazia as } \\
\text { reações de deslocamento? Tinha } \\
\text { aquelas reações de adição, dupla- } \\
\text { troca, deslocamento e } \\
\text { decomposição. Deslocamento era } \\
\text { quando... o elemento... }\end{array}$ & 口 completem & $\begin{array}{c}\mathrm{FB} \\
\mathrm{Q} \\
\mathrm{AF} \\
\mathrm{Q}\end{array}$ & $\begin{array}{c}\text { CON } \\
\text { QF } \\
\text { REV } \\
\text { CP }\end{array}$ & \\
\hline 50 & $A$ & Esqueci. & $\square$ & $\mathrm{R}$ & $\mathrm{RI}$ & \\
\hline 51 & $\mathrm{P}$ & $\begin{array}{l}\text { Esqueceu nada. Um elemento } \\
\text { deslocava o outro... do outro } \\
\text { reagente. Então, aqui: ferro e } \\
\text { cobre e o sulfato. Quem deslocou } \\
\text { quem? }\end{array}$ & $\square$ & $\begin{array}{l}\mathrm{FB} \\
\mathrm{AF} \\
\mathrm{Q}\end{array}$ & $\begin{array}{l}\text { DIS } \\
\text { INF } \\
\text { QF }\end{array}$ & \\
\hline 52 & $A$ & (...) cobre (...) ferro. & $\square$ & $\mathrm{R}$ & $\mathrm{RI}$ & \\
\hline 53 & $\mathrm{P}$ & $\begin{array}{l}\text { Quem saiu? Quem entrou? Só pra } \\
\text { eu consegui formar a próxima }\end{array}$ & $\square$ & $\mathrm{Q}$ & QF & \\
\hline
\end{tabular}




\begin{tabular}{|c|c|c|c|c|c|c|c|}
\hline & & substância aqui. & & & & & \\
\hline 54 & $\mathrm{~A}$ & O ferro saiu. & a & & $\mathrm{R}$ & $\mathrm{RI}$ & \\
\hline 55 & $P$ & $\begin{array}{l}\text { O ferro saiu e foi pro lugar de } \\
\text { quem? }\end{array}$ & a & & $\mathrm{Q}$ & QF & \\
\hline 56 & A & Do cobre. & $\square$ & & $\mathrm{R}$ & $\mathrm{RI}$ & \\
\hline 57 & $P$ & Foi pra cá? & $\square$ & $\begin{array}{l}\text { Aponta para } \\
\text { a equação } \\
\text { química na } \\
\text { lousa }\end{array}$ & Q & QF & \\
\hline 58 & A & Não, ao contrário. & 口 & & $\mathrm{R}$ & $\mathrm{RI}$ & \\
\hline 59 & $P$ & Fala, Amanda, fala! & a & & C & & \\
\hline 60 & A & $(\ldots)$ & a & & & & \\
\hline 61 & $P$ & $\begin{array}{l}\text { Então você falou que o ferro foi } \\
\text { pra onde tava o cobre. Formou o } \\
\text { que, então, Amanda? }\end{array}$ & a & & $\begin{array}{l}\mathrm{AF} \\
\mathrm{Q}\end{array}$ & $\begin{array}{c}\text { PAR } \\
\text { QF }\end{array}$ & \\
\hline 62 & A & $(\ldots)$ & 口 & & & & \\
\hline 63 & $P$ & Ferro. & & $\begin{array}{l}\text { Escreve Fe } \\
\text { na lousa }\end{array}$ & AF & INF & \\
\hline 64 & A & Sulfato. & $\square$ & & $\mathrm{AF}$ & INF & \\
\hline 65 & $P$ & Sulfato. Ele é líquido ou sólido? & 口 & & $\begin{array}{c}\text { REP } \\
\mathrm{Q}\end{array}$ & QF & \\
\hline 66 & A & (...) líquido. & a & & $\mathrm{R}$ & $\mathrm{RI}$ & \\
\hline 67 & $P$ & $\begin{array}{l}\text { Líquido. Você me falou porque tá } \\
\text { aquoso... tá na solução. E quem } \\
\text { ficou na forma de metal agora? }\end{array}$ & $\square$ & & $\begin{array}{c}\text { REP } \\
\text { AF } \\
\text { Q }\end{array}$ & $\begin{array}{l}\text { INF } \\
\text { QF }\end{array}$ & \\
\hline 68 & $\mathrm{~A}$ & O cobre. & a & & $\mathrm{Q}$ & QF & \\
\hline 69 & $P$ & $\begin{array}{l}\text { O cobre. Se o cobre ficou na } \\
\text { forma de metal, qual que é a } \\
\text { carguinha em cima dele agora? }\end{array}$ & a & & $\begin{array}{c}\text { REP } \\
\mathrm{Q}\end{array}$ & QF & \\
\hline 70 & A & Zero. & ב & & $\mathrm{R}$ & $\mathrm{RI}$ & \\
\hline 71 & $P$ & $\begin{array}{l}\text { Zero. Aconteceu, então, alguma } \\
\text { coisa esquisita, alguma coisa } \\
\text { diferente... Ah, qual é a carga do } \\
\text { sulfato? Continua. }\end{array}$ & $\square$ & & $\begin{array}{c}\text { REP } \\
\text { AF } \\
\mathrm{Q} \\
\mathrm{C}\end{array}$ & $\begin{array}{l}\text { INF } \\
\text { QF }\end{array}$ & \\
\hline 72 & A & Dois. & 口 & & $\mathrm{R}$ & $\mathrm{RI}$ & \\
\hline 73 & $\mathrm{P}$ & Se ele é dois o ferro, então, é... & & completem & Q & $\mathrm{CP}$ & \\
\hline 74 & A & Dois. & a & & $\mathrm{R}$ & $\mathrm{RI}$ & \\
\hline 75 & $P$ & $\begin{array}{l}\text { Olhando as cargas, então, o que } \\
\text { vocês podem me dizer que }\end{array}$ & D & & $\mathrm{Q}$ & & $\mathrm{QA}$ \\
\hline
\end{tabular}




\begin{tabular}{|c|c|c|c|c|c|c|}
\hline & & aconteceu? & & & & \\
\hline 76 & A & O ferro deslocou o cobre. & 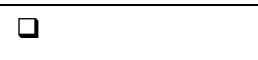 & & & \\
\hline 77 & $P$ & $\begin{array}{l}\text { Sim, o ferro deslocou o cobre. O } \\
\text { ferro que estava naquela parte do } \\
\text { bombril, ele passou para a } \\
\text { solução e o cobre... }\end{array}$ & a completem & $\begin{array}{l}\mathrm{FB} \\
\mathrm{REP} \\
\mathrm{Q}\end{array}$ & $\begin{array}{l}\mathrm{CON} \\
\mathrm{CP}\end{array}$ & \\
\hline 78 & A & Ele passou a ser (...) & 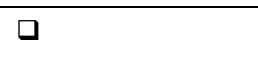 & $\mathrm{R}$ & $\mathrm{RI}$ & \\
\hline 79 & $P$ & $\begin{array}{l}\text { Ele passou a ser em volta da } \\
\text { palha de aço... ele cobriu... teve } \\
\text { uma cobertura. E a cor? }\end{array}$ & $\square$ & $\begin{array}{l}\mathrm{AF} \\
\mathrm{Q}\end{array}$ & $\begin{array}{l}\text { PAR } \\
\text { QF }\end{array}$ & \\
\hline 80 & A & $\begin{array}{l}\text { Professora! O fato de a solução } \\
\text { não ter perdido totalmente a cor } \\
(\ldots) \text { ? }\end{array}$ & a & $\mathrm{Q}$ & QF & \\
\hline 81 & $\mathrm{P}$ & $\begin{array}{l}\text { O que você acha que... Falei para } \\
\text { vocês que o sulfato de cobre (...) } \\
\text { azulzinho deixou azulzinho. Até } \\
\text { perguntei se o cobre que vocês } \\
\text { conhecem teriam a mesma cor } \\
\text { disso aqui. Se o sulfato } \\
\text { permanece na solução, quem que } \\
\text { trocou de lugar, quem que } \\
\text { mudou? }\end{array}$ & a & $\begin{array}{l}\mathrm{AF} \\
\mathrm{Q}\end{array}$ & $\begin{array}{l}\text { INF } \\
\text { QF }\end{array}$ & \\
\hline 82 & A & O cobre. & a & $\mathrm{R}$ & $\mathrm{RI}$ & \\
\hline 83 & $P$ & $\begin{array}{l}\text { Então, se mudou a cor dessa } \\
\text { solução foi por causa da saída de } \\
\text { quem? }\end{array}$ & a & $\mathrm{Q}$ & QF & \\
\hline 84 & A & Do cobre. & $\square$ & $\mathrm{R}$ & $\mathrm{RI}$ & \\
\hline 85 & $P$ & $\begin{array}{l}\text { Do cobre. O cobre saiu da forma } \\
\text { que ele tava em solução, cobre } \\
\text { dois, e passou para o metal, cobre } \\
\text { zero. Por isso troca a cor. Foi } \\
\text { aquilo que eu falei na segunda- } \\
\text { feira. Será que aquele mesmo } \\
\text { ferro da comida é o mesmo ferro } \\
\text { do material, como o prego? }\end{array}$ & $\square$ & $\begin{array}{c}\text { REP } \\
\text { AF } \\
Q\end{array}$ & QF & SIN \\
\hline 86 & A & $\begin{array}{l}\text { Só que ainda tem um restinho de } \\
\text { cor. Será que este restinho de cor } \\
\text { é do cobre? }\end{array}$ & a & $\begin{array}{l}\mathrm{AF} \\
\mathrm{Q}\end{array}$ & $\begin{array}{l}\text { INF } \\
\text { QF }\end{array}$ & \\
\hline 87 & $P$ & $\begin{array}{l}\text { Ou pode deixar como o tempo } \\
\text { que eu deixei (...) }\end{array}$ & a & & & \\
\hline
\end{tabular}




\begin{tabular}{|c|c|c|c|c|c|c|}
\hline 88 & $A^{\prime}$ & $(\ldots)$ & ם & & & \\
\hline 89 & $P$ & $\begin{array}{l}\text { Porque provavelmente não } \\
\text { terminou a reação. }\end{array}$ & a & AF & & HIP \\
\hline 90 & $A^{\prime}$ & $(\ldots)$ & ם & & & \\
\hline 91 & $P$ & $\begin{array}{l}\text { Ou tem um outro motivo. De } \\
\text { repente a quantidade de bombril } \\
\text { que eu coloquei não foi suficiente } \\
\text { para reagir com toda a solução. } \\
\text { De repente se eu tivesse colocado } \\
\text { mais bombril aqui, eu tivesse } \\
\text { mudado a cor, porque a proporção } \\
\text { que reagem... balanceamento! A } \\
\text { proporção que eu tenho dos dois } \\
\text { talvez não tenha sido } \\
\text { estequiométrica, não tenha sido } \\
\text { igualzinha pros dois a quantidade. }\end{array}$ & a & $\mathrm{AF}$ & & HIP \\
\hline 92 & A & $(\ldots)$ & $\begin{array}{l}\text { Pede a } \\
\text { palavra }\end{array}$ & & & \\
\hline 93 & $P$ & Fala! & 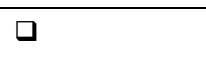 & C & & \\
\hline 94 & $A$ & $\begin{array}{l}\text { Professora, não há uma lei... não } \\
\text { lembro o nome do cara... lei que } \\
\text { você junta duas substâncias e } \\
\text { elas reagem e têm que fazer uma } \\
\text { conta pra ver quanto reage e o } \\
\text { quanto precisa pra reagir? }\end{array}$ & व & $\mathrm{Q}$ & QF & \\
\hline 95 & $P$ & $\begin{array}{l}\text { Ah tá! Foi o que eles acabaram de } \\
\text { ver, no caso aqui é o cálculo } \\
\text { estequiométrico. Pra você, } \\
\text { quantos mols de um determinado } \\
\text { reagente reagem com um } \\
\text { segundo, formando um terceiro. Aí } \\
\text { você faz o cálculo de massa, você } \\
\text { faz o cálculo de mol. É } \\
\text { estequiometria. Você balanceia } \\
\text { sua reação para saber o quanto } \\
\text { você vai ter que colocar } \\
\text { exatamente para reagir. É o que } \\
\text { acontece no processo industrial, } \\
\text { por exemplo. Você não vai } \\
\text { simplesmente pegar uma }\end{array}$ & a & $\begin{array}{l}\mathrm{Q} \\
\mathrm{Q} \\
\mathrm{Q}\end{array}$ & $\begin{array}{l}\text { EX } \\
\text { QC } \\
\text { CP }\end{array}$ & $\begin{array}{l}\text { RE } \\
\text { QA }\end{array}$ \\
\hline
\end{tabular}




\begin{tabular}{|c|c|c|c|c|c|c|}
\hline & & $\begin{array}{l}\text { quantidade qualquer de reagentes } \\
\text { e misturar. Você vai ter que } \\
\text { calcular para que não aconteça } \\
\text { nem de faltar, nem de ter excesso. } \\
\text { Certo? Agora, o que aconteceu } \\
\text { aqui? O que mudou? O ferro, ferro } \\
\text { metálico, passou a ferro... }\end{array}$ & & & & \\
\hline 96 & A & Dois & ם & $\mathrm{R}$ & RI & \\
\hline 97 & $\mathrm{P}$ & $\begin{array}{l}\text { Dois. Deixa só eu apagar aqui. } \\
\text { Vamos fazer o seguinte: se o ferro } \\
\text { estava com zero, quer dizer que } \\
\text { ele não tinha nem carga positiva, } \\
\text { nem carga negativa em excesso. } \\
\text { Ele tinha a mesma quantidade. } \\
\text { Então vou colocar aqui. Do ferro } \\
\text { zero pro ferro dois mais, o que } \\
\text { aconteceu? }\end{array}$ & a & $\begin{array}{l}\text { REP } \\
\text { AF } \\
Q\end{array}$ & $\begin{array}{l}\text { INF } \\
\text { QF }\end{array}$ & \\
\hline 98 & $\mathrm{P}$ & $\begin{array}{l}\text { Na parte de elétron que vocês } \\
\text { viram naquela hora que eu acendi } \\
\text { a luzinha. Tem uma carga elétrica } \\
\text { lá dentro. Que, nesse caso, deve } \\
\text { ter si... deve ter tido alguma } \\
\text { corrente, que foi de alguém pra } \\
\text { alguém. Do ferro zero foi pro ferro } \\
\text { dois. O que aconteceu? }\end{array}$ & a & $\begin{array}{c}\text { AF } \\
\text { REP }\end{array}$ & INF & \\
\hline 99 & A & $(\ldots)$ & ם & & & \\
\hline 100 & $\mathrm{P}$ & Mais? & a & $\mathrm{Q}$ & & QD \\
\hline 101 & A & Não, menos. & a & $\mathrm{R}$ & $\mathrm{RI}$ & \\
\hline 102 & $\mathrm{P}$ & $\begin{array}{l}\text { Que carga tem o elétron? Positiva } \\
\text { ou negativa? Qual a carga do } \\
\text { elétron, positiva ou negativa? }\end{array}$ & ם & Q & QF & \\
\hline 103 & A & Negativa. & a & $\mathrm{R}$ & $\mathrm{RI}$ & \\
\hline 104 & $\mathrm{P}$ & $\begin{array}{l}\text { Negativa. Se ele foi de zero pra } \\
\text { dois ele perdeu... }\end{array}$ & a & Q & $\mathrm{CP}$ & \\
\hline 105 & A & $(\ldots)$ & ם & & & \\
\hline 106 & $P$ & Perdeu quantos elétrons? & ם & Q & QF & \\
\hline 107 & A & Dois (...) & ם & $\mathrm{R}$ & $\mathrm{RI}$ & \\
\hline 108 & $\mathrm{P}$ & $\begin{array}{l}\text { Ah, tá! Perdeu dois elétrons. E o } \\
\text { outro que reagiu aqui foi o cobre, } \\
\text { que foi de dois mais pra... }\end{array}$ & a & $\begin{array}{c}\text { REP } \\
\mathrm{Q}\end{array}$ & $\mathrm{CP}$ & \\
\hline
\end{tabular}




\begin{tabular}{|c|c|c|c|c|c|c|}
\hline 109 & A & Zero & ם & $\mathrm{R}$ & RI & \\
\hline 110 & $\mathrm{P}$ & $\begin{array}{l}\text { Pra zero. Ele tinha dois elétrons a } \\
\text { menos. Tinha falta de dois } \\
\text { elétrons, passou a ficar com zero. } \\
\text { O que aconteceu com ele? }\end{array}$ & 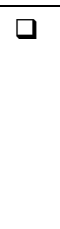 & $\begin{array}{c}\text { REP } \\
\text { AF } \\
\text { Q }\end{array}$ & $\begin{array}{l}\text { INF } \\
\text { QF }\end{array}$ & \\
\hline 111 & $A$ & Ganhou dois elétrons. & a & $\mathrm{R}$ & $\mathrm{RI}$ & \\
\hline 112 & $P$ & $\begin{array}{l}\text { Ele ganhou... ganhou dois } \\
\text { elétrons, perdeu dois elétrons. } \\
\text { Então, o que vocês podem me } \\
\text { explicar? O que aconteceu com } \\
\text { esta reação? }\end{array}$ & $\square$ & $\begin{array}{c}\text { REP } \\
\mathrm{Q}\end{array}$ & & QA \\
\hline 113 & A & $(\ldots)$ & 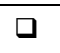 & & & \\
\hline 114 & $P$ & Não, vamos falar antes disso (...) & $\square$ & FB & DIS & \\
\hline 115 & A & $(\ldots)$ & ם & & & \\
\hline 116 & $P$ & $\begin{array}{l}\text { A gente ainda vai falar disso. Mas } \\
\text { aqui. Se esse ferro perdeu dois } \\
\text { elétrons e o cobre ganhou dois } \\
\text { elétrons, o que aconteceu? O que } \\
\text { você pode me explicar em relação } \\
\text { aos elétrons que estavam nessa } \\
\text { solução e no bombril seco? }\end{array}$ & $\square$ & $\begin{array}{l}\mathrm{O} \\
\mathrm{Q} \\
\mathrm{Q}\end{array}$ & & $\begin{array}{l}\text { QA } \\
\text { QA }\end{array}$ \\
\hline 117 & $\mathrm{P}$ & Houve uma... & 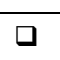 & $\mathrm{Q}$ & $\mathrm{CP}$ & \\
\hline 118 & A & Troca. & 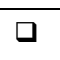 & $\mathrm{R}$ & RI & \\
\hline 119 & $P$ & $\begin{array}{l}\text { Uma troca. Quer dizer, então, que } \\
\text { os elétrons desse ferro passaram } \\
\text { pro cobre. E por isso que mudou a } \\
\text { cor. Você tinha um que era dois } \\
\text { mais e foi pra zero. Mudou a } \\
\text { espécie, mudam as } \\
\text { características também. É aí que } \\
\text { entra a parte que a Magda falou } \\
\text { de oxidação. Você falou que quem } \\
\text { que oxidou? Quem tinha oxidado } \\
\text { aqui? }\end{array}$ & ם & $\begin{array}{c}\text { REP } \\
\text { AF } \\
\text { Q }\end{array}$ & QF & SIN \\
\hline 120 & A & O ferro. & a & $\mathrm{R}$ & $\mathrm{RI}$ & \\
\hline 121 & $\mathrm{P}$ & O ferro. & a & REP & & \\
\hline
\end{tabular}


Tabela 23: Distribuição das interações Verbais e Cognitivas em E3A1PB

\begin{tabular}{|c|c|c|c|c|c|}
\hline \multirow{2}{*}{\multicolumn{2}{|c|}{ Interações Verbais }} & \multicolumn{4}{|c|}{ Interações Cognitivas } \\
\hline & & \multicolumn{2}{|c|}{ Ordem Baixa } & \multicolumn{2}{|c|}{ Ordem Alta } \\
\hline Categoria & $\mathrm{N}^{\circ}$ de Ocorrências & CAT. & $\mathrm{N}^{\circ}$ DE OC. & CAT. & $\mathrm{N}^{\circ}$ DE OC. \\
\hline $\mathrm{Q}$ & 62 & QF & 34 & QA & 10 \\
\hline $\mathrm{R}$ & 36 & $\mathrm{RI}$ & 32 & $\mathrm{RE}$ & 3 \\
\hline $\mathrm{AF}$ & 30 & INF & 21 & SIN & 3 \\
\hline REP & 26 & $\mathrm{CP}$ & 11 & HIP & 2 \\
\hline $\mathrm{O}$ & 8 & QR & 3 & QD & 1 \\
\hline FB & 4 & $\mathrm{QC}$ & 3 & & \\
\hline \multirow[t]{6}{*}{$\mathrm{C}$} & 4 & CON & 2 & & \\
\hline & & DIS & 2 & & \\
\hline & & PAR & 2 & & \\
\hline & & RD & 1 & & \\
\hline & & REV & 1 & & \\
\hline & & EX & 1 & & \\
\hline Total & 170 & Total & 113 & total & 19 \\
\hline
\end{tabular}

Continuando a atividade experimental, a professora propõe uma demonstração de reações químicas de oxidação e redução (E2A1PB). Após a realização do experimento, a discussão sobre as observações realizadas e a proposição de explicações para esses fenômenos nos dois primeiros episódios, a professora explora a representação química da reação de oxirredução de ferro com sulfato de cobre no episódio E3A1PB.

Uma primeira observação que pode ser realizada diz respeito à diminuição na proporção das interações cognitivas de ordem alta e de ordem baixa. Aparecem menos interações cognitivas de ordem alta nesse terceiro episódio (14\%) em relação ao primeiro (26\%) e segundo (23\%) episódios. Por outro lado, houve uma maior diversificação das formas de interação verbal e cognitiva na aula com a presença de hipóteses, feedbacks e sínteses.

Apesar do número relativamente grande de feedbacks (4) presentes nesse episódio, algumas falas dos alunos foram desconsideradas pela professora, como, por exemplo, na suposição de que o sulfato tivesse mudado de carga (falas 37 a 49). Ao questionar os estudantes se algum material teria sofrido alterações (37), a professora obteve como respostas que haviam ocorrido mudanças "nos dois" (38), "no cobre" (38) e no "sulfato" (42). Essa idéia dos estudantes foi reafirmada e ampliada ao mencionar que as alterações teriam ocorrido nas cargas dessas duas espécies (44-47). É provável que os estudantes estivessem relacionando o desaparecimento da cor da solução à perda da carga dos íons sulfato. A professora 
deu seqüência ao seu raciocínio tratando apenas dos metais e simplesmente ignorou a questão da mudança de carga do sulfato.

Para explicar a reação entre sulfato de cobre e o ferro da palha de aço (falas 51-62) a professora lança mão de uma classificação das reações químicas que é comumente apresentada em livros didáticos e adotada pelos professores, embora seja muito criticada pelos especialistas em ensino de Química. A professora buscou classificar essa transformação química como uma reação de deslocamento em que o ferro deslocaria o cobre do sulfato de cobre aquoso formando sulfato de ferro aquoso e liberando o cobre. Algumas críticas podem ser feitas a essas idéias: esse tipo de classificação e raciocínio é desnecessário, pois não representa nenhum ganho cognitivo para os estudantes; inúmeras transformações químicas não podem ser encaixadas em nenhum dos tipos propostos (deslocamento, dupla troca, simples troca, síntese e decomposição); dizer que uma substância desloca outra pode constituir obstáculos epistemológicos realistas que dificultariam ainda mais a aprendizagem do conceito científico de transformações químicas; pode-se desenvolver a concepção alternativa de que uma substância é mais importante do que a outra ou que uma substância mais ativa age sobre uma outra mais passiva numa transformação química ao invés da noção de interação entre os reagentes. Outro ponto ainda mais importante é que não há de fato nenhum deslocamento, pois os íons de cobre não estão ligados aos íons sulfato, mas em solução. O ferro também não se liga ao sulfato, mas passa para a solução.

Como mencionado na análise dos episódios anteriores, os elementos de contextualização apresentados nesse episódio se restringem ao uso de materiais do dia-a-dia.

Vale a pena destacar o fato de que, embora haja uma redução na quantidade de interações cognitivas de alta ordem e poucos elementos de contextualização, a aula apresentou novamente um bom nível de interatividade em que os alunos responderam e propuseram questões, fizeram comentários, observações e tiraram dúvidas. Além disso, houve uma busca constante de que eles elaborassem a idéia de transferência de elétrons numa transformação de oxirredução. 
Episódio 4 da aula 1 da professora B (E4A1PB)

\begin{tabular}{|c|c|c|c|c|c|c|}
\hline \multicolumn{7}{|c|}{ E4A1PB: Construção dos conceitos de oxidação e redução } \\
\hline \multirow[t]{2}{*}{ Turno } & \multirow{2}{*}{$\begin{array}{l}\text { Quem } \\
\text { fala? }\end{array}$} & \multirow[t]{2}{*}{ Descrição detalhada das falas } & \multirow{2}{*}{$\begin{array}{c}\text { Observações } \\
\text { contexto }\end{array}$} & \multirow{2}{*}{$\begin{array}{c}\text { Interação } \\
\text { verbal }\end{array}$} & \multicolumn{2}{|c|}{$\begin{array}{l}\text { Interação } \\
\text { cognitiva }\end{array}$} \\
\hline & & & & & B.O. & A.O. \\
\hline 1 & $\mathrm{P}$ & $\begin{array}{l}\text { Por que surgiu então essa palavra } \\
\text { "oxidação"? (...) Ah, o ferro } \\
\text { oxidou... minha porta tá oxidada }\end{array}$ & $\square$ & Q & & QA \\
\hline 2 & A & $\begin{array}{l}\text { Quando a minha mãe dizia que } \\
\text { tinha oxidado era porque eu tava } \\
\text { colocando a mão. }\end{array}$ & $\square$ & $\mathrm{R}$ & & RE \\
\hline 3 & $\mathrm{P}$ & $\begin{array}{l}\text { Xii! A sua mãe dizia que tava } \\
\text { colocando a... }\end{array}$ & प & $\begin{array}{l}\mathrm{O} \\
\mathrm{Q}\end{array}$ & $\mathrm{CP}$ & \\
\hline 4 & $A$ & As minhas mãos. & a & $\mathrm{R}$ & RI & \\
\hline 5 & $\mathrm{P}$ & As suas mãos. & $\square$ & REP & & \\
\hline 6 & A & $\begin{array}{l}\text { Ela falava: não coloque as mãos! } \\
\text { Então, eu achava que era por } \\
\text { causa do oxigênio (...) }\end{array}$ & $\square$ & $\begin{array}{l}\text { REP } \\
\text { AF }\end{array}$ & INF & \\
\hline 7 & $P$ & $\begin{array}{l}\text { Mas aí seriam outros reagentes } \\
\text { (...) Mas, então, voltando aqui. } \\
\text { Você tinha falado que o ferro tinha } \\
\text { oxidado. Por que oxidou? Eu } \\
\text { posso dizer o seguinte: Toda vez } \\
\text { que um elemento ou um reagente } \\
\text { perde elétrons, que é o caso do } \\
\text { ferro, ele sofre... }\end{array}$ & $\begin{array}{l}\text { Questão } \\
\text { retórica }\end{array}$ & $\begin{array}{c}\mathrm{AF} \\
\mathrm{Q} \\
\mathrm{AF} \\
\mathrm{Q}\end{array}$ & $\begin{array}{l}\text { INF } \\
\text { QR } \\
\text { INF } \\
\text { CP }\end{array}$ & \\
\hline 8 & A & Oxidação. & a & $\mathrm{R}$ & $\mathrm{RI}$ & \\
\hline 9 & $P$ & $\begin{array}{l}\text { Oxidação. Se alguém perdeu } \\
\text { elétrons, ele não perdeu e ficou } \\
\text { em solução, perdido no ambiente. } \\
\text { Alguém recebeu esses elétrons. } \\
\text { Quem recebeu no caso aqui foi o } \\
\text { cobre. Se ele ganhou elétrons, ele } \\
\text { sofreu... }\end{array}$ & a & $\begin{array}{l}\text { REP } \\
\text { AF } \\
Q\end{array}$ & $\begin{array}{l}\text { INF } \\
\mathrm{CP}\end{array}$ & \\
\hline 10 & $P$ & $\begin{array}{l}\text { Redução. Certo? Um vai sofrer } \\
\text { oxidação, ou seja, quem sofre } \\
\text { oxidação é aquele que tá } \\
\text { perdendo elétrons. Aquele que } \\
\text { sofre redução é aquele que ganha }\end{array}$ & a & $\begin{array}{c}\mathrm{AF} \\
\mathrm{Q} \\
\mathrm{AF} \\
\mathrm{Q}\end{array}$ & $\begin{array}{l}\text { INF } \\
\text { QC } \\
\text { INF }\end{array}$ & QA \\
\hline
\end{tabular}




\begin{tabular}{|c|c|c|c|c|c|c|}
\hline & & $\begin{array}{l}\text { os elétrons. Agora, o que isso } \\
\text { tudo tem a ver com a nossa pilha, } \\
\text { com a nossa bateria, né Daniele? } \\
\text { O que isso tudo tem a ver com a } \\
\text { nossa pilha, a nossa bateria? }\end{array}$ & & & & \\
\hline 11 & A & $\begin{array}{l}\text { Seria a troca entre um positivo e } \\
\text { um negativo e aí isso seria a } \\
\text { energia. }\end{array}$ & $\square$ & $\mathrm{R}$ & & RE \\
\hline 12 & $P$ & $\begin{array}{l}\text { Seria a troca entre um positivo e } \\
\text { um negativo. Quem seria o } \\
\text { positivo e quem seria o negativo, } \\
\text { você acha? }\end{array}$ & $\square$ & $\begin{array}{c}\text { REP } \\
\text { Q }\end{array}$ & QF & \\
\hline 13 & $P$ & $\begin{array}{l}\text { Não precisa me dar exemplo, mas } \\
\text { me dá a... }\end{array}$ & $\square$ & AF & INF & \\
\hline 14 & A & Como assim? Eu não entendi. & $\square$ & & & \\
\hline 15 & $P$ & $\begin{array}{l}\text { Você disse assim: é a troca entre } \\
\text { um positivo e um negativo. Eu } \\
\text { queria que você dissesse quem } \\
\text { poderia ser o positivo e o } \\
\text { negativo. Como podia ser? O que } \\
\text { que deixa um positivo e o outro } \\
\text { negativo? Essa transferência de } \\
\text { elétrons. Então, dentro de uma } \\
\text { pilha e uma bateria tem esses } \\
\text { dois metais, onde um tá ganhando } \\
\text { elétrons e o outro (...) Peraí, } \\
\text { pessoal (...) }\end{array}$ & $\begin{array}{l}\text { Sinal do fim } \\
\text { da aula }\end{array}$ & $\begin{array}{c}\mathrm{AF} \\
\mathrm{Q} \\
\mathrm{R} \\
\mathrm{AF}\end{array}$ & $\begin{array}{l}\text { REF } \\
\text { QR } \\
\text { RI } \\
\text { INF }\end{array}$ & \\
\hline
\end{tabular}

Tabela 24: Distribuição das interações Verbais e Cognitivas em E4A1PB

\begin{tabular}{|c|c|c|c|c|c|}
\hline \multirow{2}{*}{\multicolumn{2}{|c|}{ Interações Verbais }} & \multicolumn{4}{|c|}{ Interações Cognitivas } \\
\hline & & \multicolumn{2}{|c|}{ Ordem Baixa } & \multicolumn{2}{|c|}{ Ordem Alta } \\
\hline Categoria & $\mathrm{N}^{\circ}$ de Ocorrências & CAT. & $\mathrm{N}^{\circ}$ DE OC. & CAT. & $\mathrm{N}^{\circ} \mathrm{DE} \mathrm{OC}$ \\
\hline $\mathrm{Q}$ & 9 & INF & 8 & QA & 2 \\
\hline $\mathrm{AF}$ & 9 & $\mathrm{CP}$ & 3 & $\mathrm{RE}$ & 2 \\
\hline $\mathrm{R}$ & 5 & $\mathrm{RI}$ & 3 & & \\
\hline REP & 4 & QR & 2 & & \\
\hline \multirow[t]{3}{*}{$\mathrm{O}$} & 1 & QF & 1 & & \\
\hline & & $\mathrm{QC}$ & 1 & & \\
\hline & & REF & 1 & & \\
\hline Total & 28 & Total & 18 & total & 4 \\
\hline
\end{tabular}


Ao definir os conceitos 'oxidação' e 'redução' a professora inicia sua fala questionando os alunos sobre a origem da palavra 'oxidação'. As respostas de um dos estudantes nas falas 2, 4 e 6 relacionavam a ocorrência de oxidação com o contato com as mãos e com o oxigênio. Essas duas observações do estudante poderiam ter sido aproveitadas pela professora para comentar a influência dos eletrólitos presentes no suor das mãos, na água do mar ou em outras soluções na oxidação de objetos metálicos ou a origem do termo oxidação como sendo reação com o oxigênio. Entretanto, a professora opta por uma resposta evasiva e pela enunciação do conceito, na forma de uma questão de completar:

Quadro 1: Resposta evasiva da professora B.

\begin{tabular}{|l|l|}
\hline P & $\begin{array}{l}\text { Mas aí seriam outros reagentes (...) Mas, então, voltando aqui. Você tinha falado que o } \\
\text { ferro tinha oxidado. Por que oxidou? Eu posso dizer o seguinte: Toda vez que um } \\
\text { elemento ou um reagente perde elétrons, que é o caso do ferro, ele sofre... }\end{array}$ \\
\hline A & Oxidação. \\
\hline
\end{tabular}

Esse episódio apresentou como interações cognitivas de alta ordem duas questões abertas e duas respostas explicativas. Assim como tem sido observado nas outras aulas analisadas, as questões quase que exclusivamente partem do professor para os alunos, que têm sua participação limitada a responder as questões apresentadas pelo professor, que conduz toda a fala construída em sala de aula.

\section{Análise da aula 1 da professora B}

Pode-se observar dois momentos distintos nessa aula, tanto em termo do conteúdo abordado quanto em termo dos tipos de interações presentes. O primeiro desses momentos corresponde aos dois primeiros episódios, onde o conteúdo principal é a reflexão sobre as observações experimentais. No segundo momento, episódios 3 e 4, o discurso tem como conteúdo a sistematização científica das observações por meio da construção de uma equação química para a reação de oxirredução observada e dos conceitos de oxidação e redução. Em relação ao tipo de interações cognitivas há também diferenças entre esses dois momentos. Enquanto nos episódios 1 e 2 houve uma média de 23\% de interações cognitivas de ordem alta, essa média foi de 15\% nos episódios 3 e 4.

Por outro lado, existem semelhanças nesses dois momentos, como a distribuição praticamente constante entre o número de falas da professora e dos 
alunos, que ficou na casa dos $40 \%$ e pode ser observada nas colunas $2-4$ da tabela 25. Outra semelhança é o uso de muitas questões por parte da professora ao longo da aula. Somada as questões e respostas presentes nas falas da professora e dos alunos isso representa cerca de metade das interações verbais totais, como pode ser visto nas colunas 5-7 da tabela 25.

Tabela 25: Avaliação da Interatividade em A1PB em termos da distribuição das falas entre professore e alunos e das interações verbais

\begin{tabular}{|c|c|c|c|c|c|c|c|}
\hline 1 & 2 & 3 & 4 & 5 & 6 & 7 & 8 \\
\hline $\begin{array}{l}\frac{0}{7} \\
\frac{0}{2} \\
\frac{.0}{2}\end{array}$ & 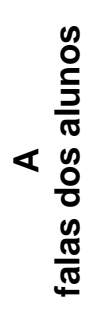 & 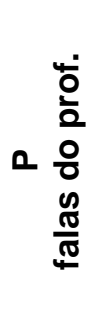 & 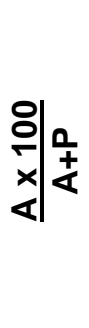 & $\begin{array}{l}\frac{r}{ \pm} \\
\text { O }\end{array}$ & 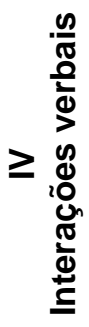 & 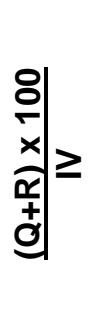 & 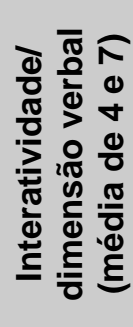 \\
\hline E1A1PB & 15 & 17 & 47 & 19 & 40 & 48 & 47 \\
\hline E2A1PB & 24 & 28 & 46 & 30 & 53 & 57 & 51 \\
\hline E3A1PB & 59 & 62 & 49 & 98 & 170 & 58 & 53 \\
\hline E4A1PB & 6 & 9 & 40 & 14 & 28 & 50 & 45 \\
\hline
\end{tabular}

A aula da professora B pode então ser considerada interativa visto que ao longo de toda a aula os alunos participam das reflexões e explicações sobre os experimentos respondendo as questões da professora ou completando suas frases. Essas interações se deram, sobretudo, na forma de questões que partiram da professora e respostas dadas pelos alunos.

Tabela 26: Avaliação do Nível Cognitivo em A1PB em função das interações cognitivas de alta e baixa ordem e em função das questões e respostas de alta e baixa cognitiva.

\begin{tabular}{|c|c|c|c|c|c|c|}
\hline 1 & 2 & 3 & 4 & 5 & 6 & 7 \\
\hline 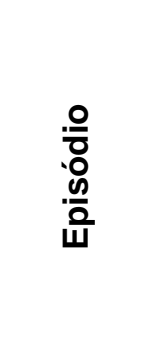 & 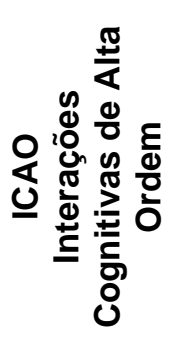 & 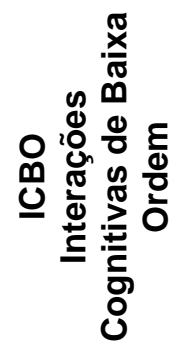 & 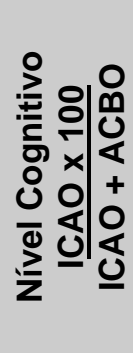 & 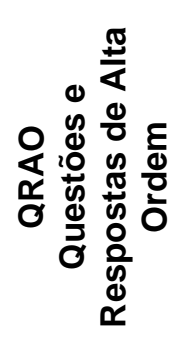 & 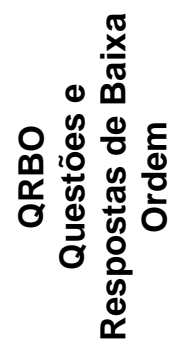 & 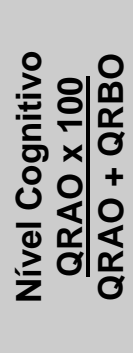 \\
\hline E1A1PB & 9 & 26 & 26 & 9 & 11 & 45 \\
\hline E2A1PB & 8 & 32 & 20 & 7 & 23 & 23 \\
\hline E3A1PB & 19 & 113 & 14 & 14 & 84 & 14 \\
\hline E4A1PB & 4 & 18 & 18 & 4 & 10 & 29 \\
\hline
\end{tabular}


O nível cognitivo da aula foi baixo nos quatro episódios. Houve também pouco uso de outras formas de interações cognitivas que não as questões e respostas, que correspondem quase à totalidade das interações, como mostram as colunas 2 e 5 da tabela 26.

Um ponto fundamental que deve ser considerado nessa aula é o fato de os episódios 1 e 2, como mencionado antes, apresentarem melhores níveis cognitivos se comparados aos dois últimos episódios. A análise das falas desses episódios indica que essa diferença pode ser atribuída ao uso da experimentação e não aos poucos e rápidos momentos de contextualização do conteúdo científico, que são apresentados no quadro a seguir.

Quadro 2: Elementos de Contextualização em A1PB

\begin{tabular}{|l|l|}
\hline E1A1PB & funcionamento de lâmpada, rádio e pilha \\
\hline E2A1PB & $\begin{array}{l}\text { bijuterias 'banhadas'; uso de clipe metálico e palha de aço na } \\
\text { experimentação }\end{array}$ \\
\hline E3A1PB & processo industrial \\
\hline E4A1PB & oxidação de metais presentes em casa; pilhas e baterias) \\
\hline
\end{tabular}

A contextualização aqui aparece principalmente na forma de demonstrações de aplicações dos conhecimentos científicos no cotidiano dos estudantes e parece ter a função de motivar os estudantes ou aumentar o interesse pelo assunto da aula, reações de oxirredução. Os exemplos do cotidiano mencionados não tinham a finalidade de serem os objetos de conhecimento da aula, mas apenas a função de motivador os estudantes para aprenderem os conceitos científicos. Essa forma de tratar o cotidiano nas aulas de Química é considerada por Lutfi (1992) como a forma mais primária de contextualização.

Pode-se considerar que a pequena inserção de conteúdos contextualizados nessa aula esteja relacionada à baixa freqüência em que as interações cognitivas de ordem alta aparecem nesses quatro episódios.

Em geral, as interações cognitivas de alta ordem estão associadas nessa aula à experimentação, como pode ser visto na tabela 27. Nela são mostradas as interações cognitivas que estão relacionadas diretamente aos experimentos de condutibilidade e oxirredução. Como pode ser observado na tabela, 24 das 40 
interações cognitivas de ordem alta apresentadas nessa aula estão ligadas diretamente à discussão dos experimentos.

Tabela 27: Relação entre a experimentação e as interações cognitivas de ordem alta na aula da professora B.

\begin{tabular}{|c|c|c|c|}
\hline $\begin{array}{c}\text { Episódios de } \\
\text { A1PB }\end{array}$ & Turno de fala & $\begin{array}{l}\text { Interações } \\
\text { Cognitivas de } \\
\text { Ordem Alta }\end{array}$ & $\begin{array}{c}\text { Relação com os } \\
\text { Experimentos } \\
\text { ( + ) apresenta } \\
\text { ( - ) não apresenta }\end{array}$ \\
\hline \multirow{10}{*}{ E1 } & 1 & $\mathrm{QA}$ & + \\
\hline & 2 & $\mathrm{RE}$ & + \\
\hline & 9 & QA & + \\
\hline & 13 & QS & - \\
\hline & 14 & RE & - \\
\hline & \multirow{2}{*}{16} & QA & - \\
\hline & & QA & - \\
\hline & 18 & QA & - \\
\hline & 24 & QA & + \\
\hline & \multicolumn{2}{|c|}{ TOTAL } & $4 / 9$ \\
\hline \multirow{9}{*}{ E2 } & 1 & HIP & + \\
\hline & 7 & QA & + \\
\hline & 11 & QA & + \\
\hline & 26 & QA & + \\
\hline & 33 & QA & + \\
\hline & 37 & RE & + \\
\hline & 41 & $\mathrm{RE}$ & + \\
\hline & 50 & QA & + \\
\hline & \multicolumn{2}{|c|}{ TOTAL } & $8 / 8$ \\
\hline \multirow{18}{*}{ E3 } & \multirow{2}{*}{5} & QA & + \\
\hline & & QA & + \\
\hline & 7 & $\mathrm{RE}$ & + \\
\hline & 8 & $\mathrm{RE}$ & + \\
\hline & 9 & QA & + \\
\hline & 12 & SIN & + \\
\hline & 21 & QA & - \\
\hline & 37 & QA & + \\
\hline & 75 & QA & - \\
\hline & 85 & SIN & + \\
\hline & 89 & HIP & + \\
\hline & 91 & HIP & + \\
\hline & \multirow{2}{*}{95} & $\mathrm{RE}$ & - \\
\hline & & QA & - \\
\hline & 100 & QD & - \\
\hline & 112 & QA & - \\
\hline & \multirow{2}{*}{116} & QA & - \\
\hline & & QA & + \\
\hline
\end{tabular}




\begin{tabular}{|c|c|c|c|}
\hline & 119 & SIN & + \\
\hline & & & $12 / 19$ \\
\hline & 1 & $\mathrm{QA}$ & - \\
\hline & 2 & $\mathrm{RE}$ & - \\
\hline E4 & 10 & $\mathrm{QA}$ & - \\
\hline & 11 & RE & - \\
\hline & & & $0 / 4$ \\
\hline & $D A$ & & $24 / 40$ \\
\hline
\end{tabular}

As interações que não apresentam relações diretas com os experimentos estão relacionadas, sobretudo, com a representação da equação química da reação entre o sulfato de cobre e ferro da palha de aço, com os conceitos de oxidação e redução e, em menor quantidade, com os conteúdos de contextualização desses conhecimentos científicos.

A interatividade e o nível cognitivo das interações dessa aula estão representados no gráfico 3 , que apresenta uma caracterização da aula.

Gráfico 3: Caracterização da aula 1 da professora B: Aula Interativa de Baixa Ordem Cognitiva

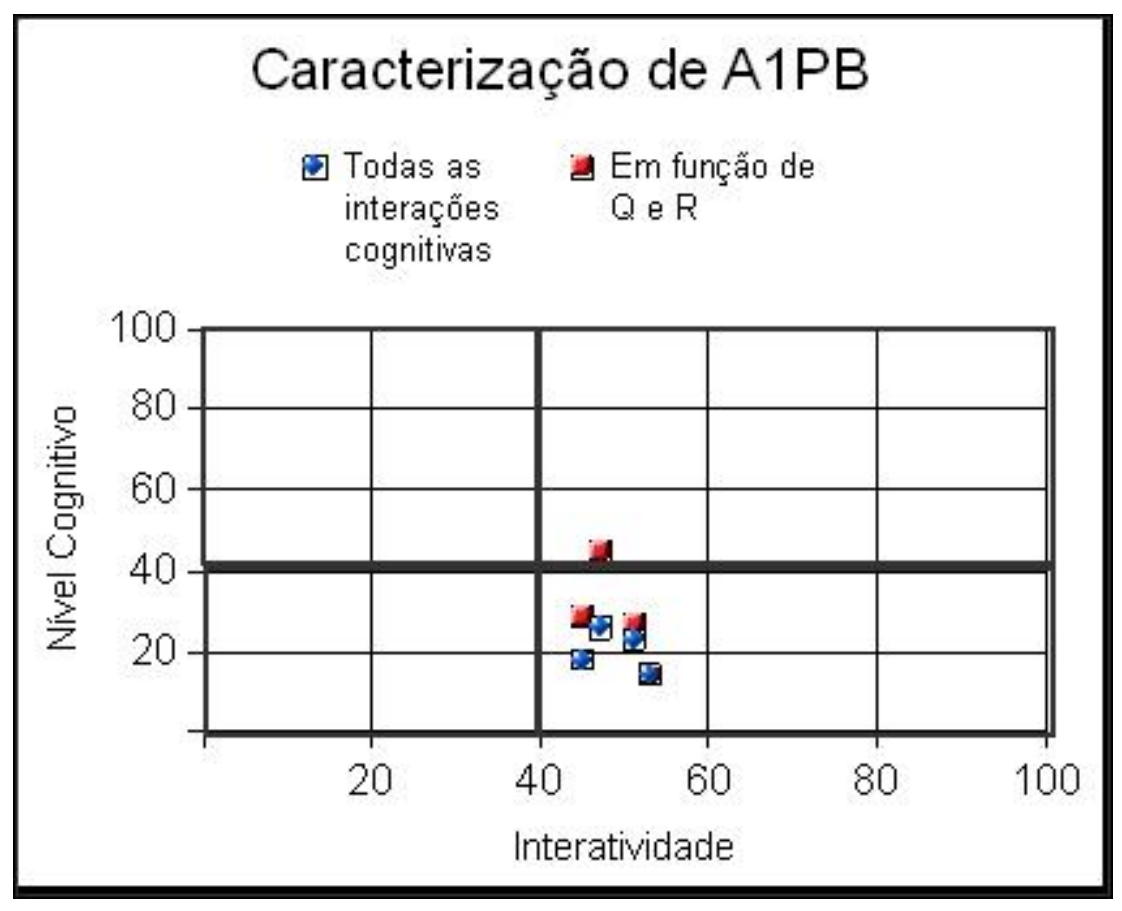

De acordo com o modelo proposto e aplicado nas aulas analisadas, essa aula pode então ser considerada uma aula interativa de baixa ordem cognitiva. 


\section{3 - Considerações gerais sobre as três aulas analisadas}

As análises das duas aulas da professora A e da aula da professora B permitem tecer a seguinte consideração: a contextualização dos conhecimentos científicos está relacionada a uma melhora no nível cognitivo das interações discursivas construídas entre professora e alunos, mesmo que o nível alcançado não seja o ideal. Em outras palavras, mesmo que o nível cognitivo das interações discursivas das aulas não tenha sido satisfatório (dentro do modelo aqui proposto para a análise das aulas) fica perceptível a correlação positiva entre a contextualização do conteúdo e o nível cognitivo dessas interações. No caso da aula da professora $B$ essa relação também pode ser feita entre a experimentação e o nível cognitivo da aula.

Contudo, é preciso frisar que essa afirmação diz respeito às aulas analisadas e não tem a pretensão de ser generalizada para outras aulas ou professores. É preciso lembrar também que a contextualização (e a experimentação) pode ser conduzida de diferentes maneiras dependendo da visão de ensino e de aprendizagem do professor, podendo recorrer a um modelo de ensino mais pautado na transmissão de conhecimentos ou com abordagens mais construtivistas e dialógicas.

Com respeito à dimensão verbal das interações discursivas pode-se considerar que: a interatividade das aulas é independente do conteúdo em discussão e não tem relação com o nível cognitivo das interações discursivas, estando, provavelmente, mais ligada às concepções pedagógicas do professor e outras características pessoais.

Essas idéias podem ser representadas através da figura seguir. 


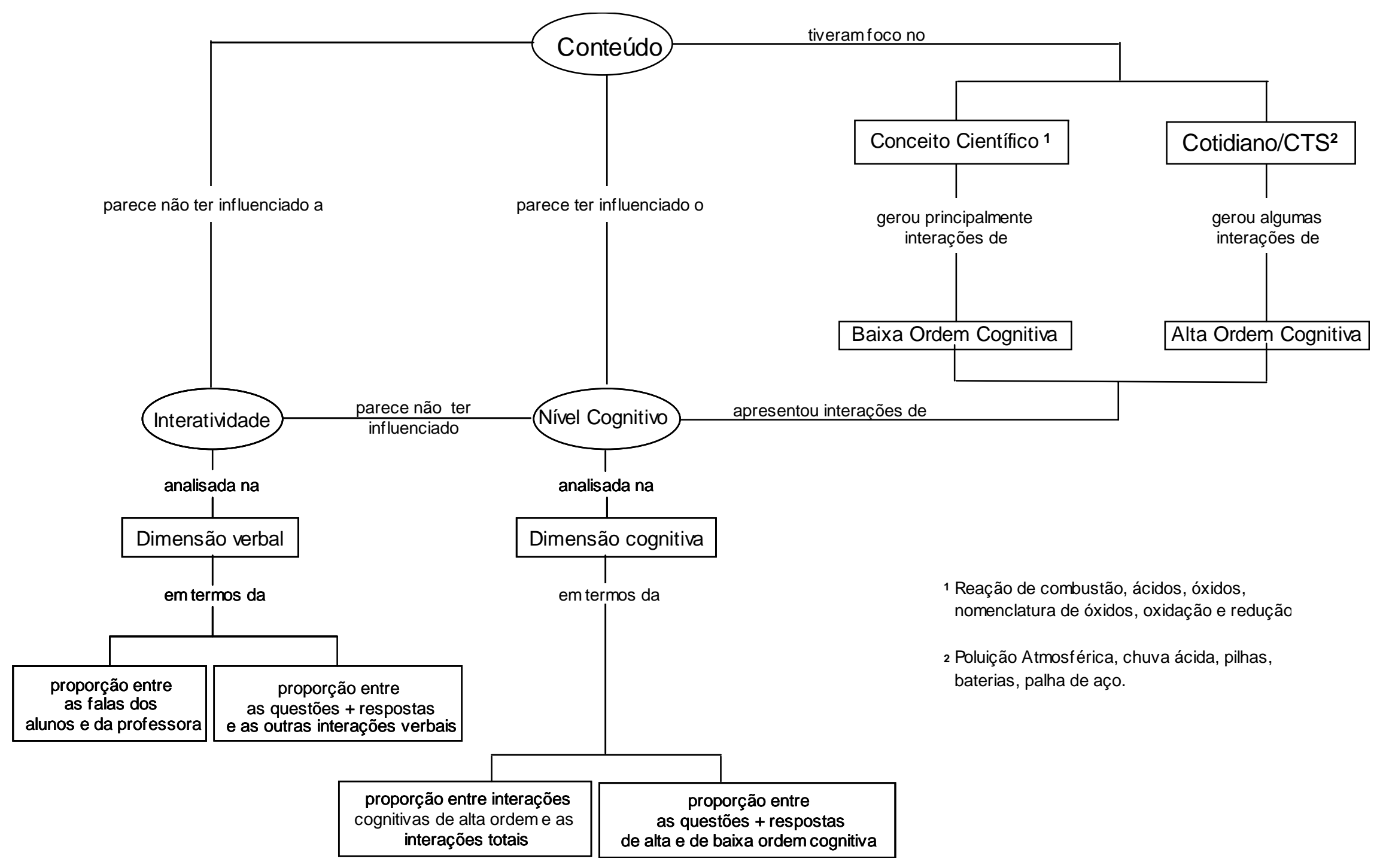

Figura 1: Relação entre a Interatividade, o Nível Cognitivo e os Conteúdos das três aulas analisadas. 
As aulas analisadas foram bastante dialogadas e interativas, com um grande número de questões feitas quase sempre pelas professoras e respostas dadas quase sempre pelos alunos. Pode-se dizer que, embora as aulas tenham sido bastante diferentes quanto ao enfoque dado, todas foram interativas.

As professoras se mostraram bastante receptivas às falas dos alunos por apresentar poucos momentos de discordância não justificada e por diversas vezes ter usado da 'repetição', REP, para valorizar as falas dos alunos. Essa valorização da fala do aluno foi um fator importante na promoção do diálogo nas aulas, mas também controverso já que eles não trouxeram novos elementos às discussões, tendo sua participação limitada a responder as questões propostas pelas professoras. Não houve, por parte dos estudantes, questões, comentários, dúvidas ou levantamento de hipótese, mesmo sendo abordados durante as aulas assuntos como doenças, carros, combustíveis, poluição, impactos ambientais, chuva ácida, pilhas e baterias, corrosão de objetos metálicos.

Os registros das aulas indicam que o uso da contextualização não está relacionado a uma maior ou menor interatividade na aula, mas sim ao nível cognitivo dela. O fato de os alunos terem voz durante as aulas, mesmo o professor mantendo um diálogo de autoridade, depende mais das características de cada professor do que do conteúdo tratado na aula. Essas 'características do professor', que podem levá-lo a questionar seus alunos, poderiam estar relacionadas a fatores pedagógicos tais como compreensão do processo de ensino e de aprendizagem, manutenção da disciplina ou mesmo a fatores pessoais como timidez e autoconfiança.

\section{5 - Conclusões e Considerações finais}

Cabe neste momento retomar a hipótese de trabalho levantada no início desta investigação:

Nesta investigação, parto da hipótese de que a contextualização do conhecimento científico, embora necessária, não garante o estabelecimento de interações discursivas que evidenciem um alto nível de envolvimento cognitivo por parte dos alunos. Em outras palavras, defendo o ponto de vista de que a incorporação de conteúdos mais próximos à vivência dos alunos, mesmo que gere maior interesse e participação na aula, não leva necessariamente à construção de conhecimento, 
mas pode simplesmente redundar na troca dos conteúdos a serem memorizados e algoritmos a serem automatizados.

Ao menos em parte essa hipótese foi confirmada na análise das aulas investigadas. Apesar do fato da contextualização dos conhecimentos científicos estar associada ao aumento na freqüência das interações cognitivas de alta ordem, a contextualização não mostrou relação com a participação dos estudantes na aula. Além disso, as interações cognitivas de alta ordem são quase sempre geradas pelo professor e não pelos alunos. Apenas as falas das professoras mostraram maior grau de elaboração nos momentos de contextualização do conhecimento. Assim, tratar de assuntos do cotidiano dos estudantes ou de importância social, tecnológica ou ambiental teve maior efeito na fala das professoras, tornando-as mais elaboradas, do que nas falas dos estudantes.

Retomando também os objetivos iniciais da investigação que são

[...] conhecer a natureza das interações verbais e cognitivas estabelecidas entre professor e aluno e entre os próprios alunos nas aulas em que o ensino de Química é contextualizado.

$\mathrm{e}$

[...] compreender melhor tanto a dinâmica das interações em sala de aula quanto o papel da contextualização dos conhecimentos científicos nelas.

posso considerar que os tenha alcançado. Desta maneira, apresento a seguir algumas conclusões e considerações finais sobre a investigação que tenho levado a cabo.

Embora a contextualização seja um importante referencial teórico apontado tanto pela academia quanto pelos governos como sendo um princípio norteador da prática educativa, sobretudo na educação básica, esse fundamento aparece pouco nas aulas de Química, a julgar pelas aulas gravadas e analisadas nesta investigação. Mesmo para os professores que se posicionam favoravelmente à inserção de conteúdos do cotidiano ou CTSA nas aulas de Química, a prática desse princípio parece não ser algo trivial visto que no decorrer desta investigação pôde-se perceber que poucos o utilizam. Mesmo formas de contextualização simplistas como 
a exemplificação de aplicações tecnológicas dos conteúdos científicos aparece pouco nas aulas de química. De fato essa carência é preocupante.

A contextualização deve ser observada nas aulas de Química independentemente de auxiliar de alguma forma na aprendizagem dos conteúdos científicos. Há uma preocupação excessiva e exclusiva com a aprendizagem de conceitos científicos, deixando de lado outros conteúdos ligados à ciência e que são essenciais na formação científica e geral dos estudantes. Entretanto, parece ficar nas entrelinhas que a função dos professores é ensinar os conceitos científicos e as aplicações e implicações da ciência e suas relações interdisciplinares deveriam ficar por conta do próprio estudante, como se isso fosse algo simples de ser realizado. Talvez por isso muitos professores abram mão da discussão de temas científicos ligados ao cotidiano e dêem preferência aos conteúdos conceituais já consagrados no currículo da Química.

Dentre os professores que defendem a contextualização, parte deles o faz por crerem que através desta forma de ensino os estudantes participarão mais das aulas e aprenderão mais facilmente os conteúdos químicos. Entretanto, um dos pontos que ficou evidente nesta investigação foi o fato de a participação dos estudantes ser pouco ou nada influenciada pela contextualização dos conteúdos. Tanto em aulas onde o foco foi a poluição atmosférica, quanto nas aulas onde o foco foi a nomenclatura de óxidos ou a discussão sobre reações de oxirredução a forma de participação dos estudantes foi basicamente a mesma: muitas falas curtas e pouco elaboradas. Embora as falas dos professores tenham mostrado maior influência do conteúdo abordado, como foi comentado anteriormente, as falas dos estudantes não acompanharam essas mudanças no mesmo ritmo. Mesmo diante de questões abertas que permitiriam como respostas explicações para um fenômeno, as respostas dos estudantes muitas vezes eram pouco elaboradas. Assim, o fato de o estudante falar muito durante a aula não tem relação direta com a aprendizagem dos conteúdos da Química. Não se defende aqui uma aula pautada no modelo de transmissão cultural na qual só o professor fale o tempo todo, pelo contrário. As aulas devem permitir que os estudantes expressem de forma mais completa suas idéias sobre os fenômenos estudados. Os melhores momentos das aulas foram aqueles em que as professoras motivaram seus estudantes para que aprofundassem suas reflexões e explicações sobre os fenômenos. Isso se deu, por exemplo, quando uma professora pede que o estudante explique sua resposta 
pouco elaborada ou quando o professor busca causar um desequilíbrio cognitivo no estudante confrontado sua fala com outra questão.

Uma compreensão mais aprofundada das interações discursivas produzidas nas aulas só foi possível através da aplicação do instrumento de análise construído a partir dos referenciais teóricos, das revisões bibliográficas, das análises preliminares das transcrições e das contribuições dos colaboradores do grupo de discussão da Professora Doutora Maria Eunice Ribeiro Marcondes. O instrumento (categorias de análise e mapas analíticos) possibilitou obter tanto um espectro detalhado das aulas quanto um panorama geral e bastante preciso. Certamente esse instrumento necessita ser revisado e aprimorado, mas servirá como ferramenta analítica para futuras investigações e para outros pesquisadores.

Ao longo das análises dos episódios percebeu-se a necessidade de aprofundamento de alguns referenciais teóricos abordados no capítulo sobre a fundamentação teórica e sobre a metodologia de análise. Foi o caso da utilização das idéias de Mortimer e Scott (2002) na caracterização das aulas. Esse referencial foi importante no sentido de possibilitar a diferenciação entre os estilos de interatividade possíveis de serem observados nas aulas: aulas interativas ou não interativas. Outro aspecto importante foi a diferenciação entre as formas de tratar o conhecimento em sala de aula que, segundo os autores, poderia ser um discurso dialógico ou de autoridade. Essa diferenciação no tratamento do conhecimento foi incorporada nas análises realizadas e relacionada com as aulas de baixo e alto nível cognitivo. Avaliou-se a interatividade em termos das interações verbais produzidas nas falas das professoras e dos alunos e o nível cognitivo em termos das interações cognitivas de baixa e alta ordem.

A partir da aplicação do instrumento e das análises qualitativas realizadas alguns resultados interessantes puderam ser obtidos nesta investigação. Dentre eles, pode-se se destacar o seguinte:

- As professoras buscaram manter um nível de interatividade alto e constante ao longo da aula. Isto se fez usando de três estratégias principais:

o Uso das repetições das falas dos alunos como forma de valorização da participação destes;

o Uso de questões simples, sobretudo questões fechadas (QF) e questões de completar a frase (CP); 
o Ausência de feedbacks (FB) negativos (DIS) diante de respostas incorretas, as quais eram simplesmente ignoradas.

- Aparição em alguns momentos de padrões de interação do tipo QF-RI-QD (tríade formada por questão fechada - resposta informativa - questão de desequilíbrio) como forma de:

o Substituição de questões abertas que cumpririam o mesmo papel da tríade. A tríade parece deixar os alunos mais confiantes para responderem às questões pelo fato da QF ser, geralmente, mais simples do que uma questão aberta.

o Valorização da fala do aluno por dar a ele a oportunidade de expor e ampliar seu raciocínio.

- Levar o aluno a refletir sobre sua resposta e reformulá-la ou ampliá-la aumentando o nível cognitivo das interações.

- Os diálogos foram conduzidos invariavelmente pelas professoras. Foram raros os momentos em que a participação dos estudantes foi de fato ativa, mesmo nos episódios em que houve maior contextualização. Em geral os estudantes se limitaram a responder as questões propostas pela professora e não trouxeram a tona assuntos que pudessem ser relacionados aos contextos discutidos em aula.

- A contextualização (e a experimentação) possibilitou o aumento das interações cognitivas de ordem alta.

- A contextualização (e a experimentação) não influenciou a interatividade no discurso entre professoras e alunos.

- A maioria das interações cognitivas de ordem alta estava associada às professoras e aquelas que foram geradas pelos alunos ocorreram devido às intervenções das professoras. Mesmo que a fala das professoras tenham sido mais elaborada, ou seja, tenham usado de interações cognitivas de ordem alta, a fala dos alunos, na maioria das vezes, tende a simplificação e a interações cognitivas de ordem baixa.

- Episódios das aulas que enfocaram a poluição atmosférica e a experimentação geraram maior número de interações cognitivas de ordem alta do que os episódios das aulas que enfocaram a nomenclatura dos óxidos e as reações de oxirredução. 
- As interações mais freqüentes são as questões e respostas, partindo estas dos alunos e aquelas das professoras. Predominam as questões fechadas ou de completar as frases e as respostas informativas, em geral evocação de memória.

o Algumas formas de interações apareceram pouco: respostas descritivas (RD), exemplificação (EX), paráfrase (PAR), reformulação (REF), discordância (DIS), concordância (CON), revisão (REV), questão subjetiva (QS), síntese (SIN), hipótese (HIP), convite (C).

o Outras formas de interação não apareceram em nenhuma aula: análise (ANLS), analogia (ANLG), juízo de valores (JV), ditado (D).

A partir desses resultados pode-se perceber a necessidade de se refletir sobre o discurso construído em sala de aula e o quanto ele pode ser melhorado. $O$ uso de diversas formas de interações cognitivas, em especial as de ordem alta, além das freqüentes questões e respostas, pode auxiliar a construção do conhecimento científico por parte dos estudantes. É preciso que essas reflexões ocorram entre os professores nos espaços de formação inicial e continuada para que essas idéias sobre as interações discursivas sejam consideradas e incorporadas no dia-a-dia da sala de aula. É interessante a reação de alguns professores quando vêem as gravações de suas aulas ou lêem as transcrições delas (como ocorreu comigo durante minha graduação). Muitos dizem espantados "Eu falo assim?!" ou "Não acredito que eu disse isso!". Em geral esse olhar sobre a própria prática gera desconforto e frustração no início, mas promove uma auto-conscientização sem precedentes para o professor. A verdade é que dificilmente se consegue refletir de forma aprofundada sobre a própria prática no momento em que a executa. Essa reflexão, no caso do professor, se faz melhor longe do "calor da sala de aula", de preferência junto com os pares e balizada por alguns referenciais teóricos. Assim, espera-se que este trabalho de investigação possa contribuir em alguma medida às reflexões de professores e formadores de professores no que diz respeito às interações discursivas construídas em sala de aula entre professor e alunos e a relação disso com a contextualização dos conhecimentos científicos.

Em relação à importância desta pesquisa em minha formação como pesquisador é difícil mensurar as contribuições alcançadas pela oportunidade de vivenciar a pesquisa acadêmica em todas as suas etapas e pelos resultados obtidos 
nela. O que de fato sei é que essas contribuições certamente terão reflexos positivos nos mais diversos âmbitos da minha atuação profissional, quer seja como futuro pesquisador da área de educação química, quer seja como formador de opinião nos cursos, palestras e oficinas que tenho ministrado ou na minha prática como professor de Química e Ciências no fronte de batalha. 
6 - Bibliografia e referências bibliográficas

Foi utilizada nesse capítulo a Norma para referências bibliográficas NBR 6023:2002 da ABNT - Associação Brasileira de Normas Técnicas.

ACeVedo díAZ, J. A.; Alonso, A. V.; MANASSERo MAS, M. A. Papel de la educación CTS en una alfabetización científica y tecnológica para todas las personas. Revista Electrónica de Enseñanza las Ciencias. v. 2, n. 2, p. 1-32, 2003.

AIKENHEAD, G. Educación Ciencia-Tecnología-Sociedad (CTS): una buena idea como quiera que se le llame. Educación Quimica. v. 16, n. 2, p. 304-314, 2005.

ANDRÉ, M. E. D. A. Etnografia da prática escolar. 5a ed. São Paulo: Papirus, 2000. (Série Prática Pedagógica)

AULER, D. Alfabetização Científico-Tecnológica: Um novo "Paradigma"? Ensaio. v. 5, n. 1, p. 1-16, 2003.

BARREIRO, L. M. R.; ESCORZA, T. E. Interacción entre iguales y aprendizaje de conceptos científicos. Enseñanza de las Ciencias. v. 18, n. 2, p. 255-274, 2000.

BENNETT, J.; HOGARTH, S.; LUBBEN, F. A systematic review of the effects of context-based and Science-Technology-Society (STS) approaches in the teaching of secondary science. 2003. 68f. Revisão Bibliográfica. Instituto de Educação, Universidade de Londres, Londres, 2003.

BIANCHINI, J. A. Where knowledge construction, equity, and context intersect: student learning of science in small group. Journal of Research in Science Teaching. v. 34, n. 10, p. 1039-1065, 1997.

BRASIL. Ministério da Educação. Secretaria da Educação Média e Tecnológica. Parâmetros Curriculares Nacionais - Ensino Médio. Brasília, 1999.

. PCN+: Parâmetros Curriculares Nacionais - Ensino Médio. Brasília, 2002. 
CANDELA, A. A construção discursiva de contextos argumentativos no ensino de ciências. In: COLL, C., EDWARDS, D. (Orgs.) Ensino, aprendizagem e discurso em sala de aula: aproximações ao estudo do discurso educacional. Porto Alegre: Artmed, 1998, p. 143-169.

CAPECCHI, M. C. V. M.; CARVALHO, A. M. P.; SILVA, D. Argumentação dos alunos e discurso do professor em uma aula de Física. Ensaio. v. 2, n. 2, p. 189-208, 2000.

CÁRDENAS, G. M.; BENIITEZ, Y. G.; PINEDA, E. R.; GARCÍA, O. R.; LEYVA, H. R. Análisis de las interacciones maestra-alumnos durante la enseñanza de las ciencias naturales en primaria. Revista Mexicana de Investigación Educativa. v. 9, n. 22, p. 721-745, 2004.

CORDEIRO, S.; COLIVAUX, D.; DUMRAUF, A. G. Y si trabajan em grupo...? Interaciones entre alumnos, procesos sociales y cognitivos en clases universitarias de Física. Enseñanza de las Ciencias. v. 20, n. 3, p. 427-441, 2002.

DELIZOICOV, D.; ANGotTI, J. A.; PeRnAmbuCo, M. M. Ensino de Ciências: fundamentos e métodos. São Paulo: Cortez, 2002.

DE LONGHI, A. L. El discurso del profesor y del alumno: análisis didáctico en clases de ciencias. Enseñanza de las Ciencias. v. 18, n. 2, p. 201-216, 2000.

GARRIDO, E. Analisando a interação verbal professor-alunos segundo categorias baseadas no Modelo de Mudança Conceitual. In: Brzezinski, I. (Org.). Formação de professores: um desafio. Goiânia: Editora da Universidade Católica de Goiás, 1996, p. $179-211$.

JOHNSON, D. W.; JOHNSON, R. T. Effects of cooperative and individualistic learning experiences on inter-ethnic interaction. Journal of Educational Psychology. v. 73 , n. 3, p. 444-449, 1981. 
KUMPULAINEN, K.; MUTANEN, M. The situated dynamics of peer group interaction: an introduction to an analytic framework. Learning and Instruction. n. 9, p. 449-473, 1999.

LONNING, R. A. Effect of cooperative learning strategies on student verbal interactions and achievement during conceptual change instruction in $10^{\text {th }}$ grade general science. Journal of Research in Science Teaching. v. 30, n. 9, p. 1087-1101, 1993.

LUMPE, A. T. Peer collaboration and concept development: learning about photosynthesis. Journal of Research in Science Teaching. v. 32, n. 1, p. 71-98, 1995.

LUTFI, M. Os ferrados e os cromados. Ijuí: UNIJUÍ, 1992.

MATUI, J. Construtivismo: teoria construtivista sócio-histórica aplicada ao ensino. São Paulo: Moderna, 1995.

MOREIRA, M. A. O domínio metodológico da pesquisa em ensino. In: Pesquisa em Ensino de Física: o vê epistemológico de Gowin. São Paulo: EPU, 1990. cap. 2, p.13-45.

MORGE, L. Teacher-pupil interaction: A study of hidden beliefs in conclusion phases. International Journal of Science Education. v. 27, n. 8, p. 935-956, 2005.

MORTIMER, E. F. e SCOTT, P. Atividade discursiva nas aulas de Ciências: Uma ferramenta sociocultural para analisar e planejar o ensino. Investigações em Ensino de Ciências. v. 7, n. 3, p. 1-26, 2002.

POSNER, G. J.; STRIKER, K. A. Conceptual change and science teaching. International Journal of Science Education. v. 4, n. 3, p. 231-240, 1982.

RICHMOND, G.; STRILEY, J. Making meaning in classrooms: social processes in small-group discourse and scientific knowledge building. Journal of Research in Science Teaching. v. 33, n. 8, p. 839-858, 1996. 
SANTOS, W. L. P.; MORTIMER, E. F.; SCOTT, P. H. A argumentação em discussões sócio-científicas: Reflexões a partir de um estudo de caso. Revista Brasileira de Pesquisa em Educação em Ciências. v. 1, n. 1, p. 140-152, 2001.

SÃO PAULO (Estado). Secretaria da Educação. Coordenadoria de Estudos e Normas Pedagógicas. Proposta Curricular para o Ensino de Química - $2^{\circ}$ grau. São Paulo: SE/CENP, 1992.

SOLBES, J.; VILCHES, A. La introducción de las relaciones Ciencia, Tecnología y Sociedad en la enseñanza de las ciencias e su evolución. Educación Quimica. v. 11, n. 4, p. 387-394, 2000.

STAMOVLASIS, D.; TSAPARLIS, G.; KAMILATOS, C.; PAPAOIKONOMOU, D.; ZAROTIADOU, E. Conceptual understanding versus algorithmic problem solving: Further evidence from a national chemistry examination. Chemistry Education Research and Practice. v. 6, n. 2, p. 104-118, 2005.

TALANQUER, V. El movimiento CTS en México, ¿vencedor vencido? Educación Quimica. v. 11, n. 4, p. 381-386, 2000.

TOWNS, M. H.; KREKE, K.; FIELDS, A. A action research project: student perspectives on small-group learning in chemistry. Journal of Chemical Education. v. 77, n. 1, 2000.

ZOLLER, U. The fostering of question-asking capability: A meaningful aspect of problem-solving in chemistry. Journal of Chemical Education. v. 64, n. 6, p. 510-512, 1987.

ZOLLER, U. Are lecture and learning: are they compatible? maybe for LOCS; unlikely for HOCS. Journal of Chemical Education. v. 70, n. 3, p. 195-197, 1993. 
ZOLLER, U. Scaling-Up of Higher-Order Cognitive Skills-Oriented College Chemistry Teaching: An Action-Oriented Research. Journal of Research in Science Teaching. v. 36, n. 5, p. 583-596, 1999.

ZOLLER, U. Interdisciplinary Systemic HOCS Development - The Key for meaningful STES oriented Chemical education. Chemistry Education: Research and Practice in Europe. v. 1, n. 2, p. 189-200, 2000.

ZOLLER, U.; LUBEZKY, A.; NAKHLEH, M. B.; TESSIER, B.; DORI, Y. J. Success on algorithmic and LOCS vs. conceptual chemistry exam questions, Journal of Chemical Education. n. 72, p. 987-989, 1995.

ZOLLER, U.; TSAPARLIS, G. Higher- and lower-order cognitive skills: the case of chemistry. Research in Science Education. n. 27, p. 117-130, 1997. 